\title{
Fashioning Immersive Displays in Egypt and Beyond
}

Among the collectors who lent works of Islamic Art to the 1865 and 1869 retrospective shows of the Union centrale des beaux-arts appliqués à l'industrie in Paris, two groups can tentatively be differentiated in terms of display. On the one hand, were art lovers who typically kept their pieces in glass cases and cabinets, such as the Marquess of Hertford, or alternatively were to install "treasure chambers" (in German, Schatzkammer), as the Rothschilds famously did. Alphonse de Rothschild, who exhibited "Arab" enamelled glass in 1865 , had his precious specimens, together with rock crystal, carved ivories and medieval enamels, locked in a mezzanine room at his hôtel particulier [private mansion] on 2 Saint-Florentin Street in Paris. The smoking room created in 1889 by Ferdinand de Rothschild at Waddesdon Manor for his valuable Renaissance Museum, visually epitomises how objects, such as the famous Palmer Cup (a thirteenth-century enamelled glass beaker from Egypt or Syria mounted on a French silver-gilt foot) and a Mamluk mosque lamp, were presented: they were lined up and protected under glass. ${ }^{1}$ (Fig. 87) On the other hand were artists, architects and would-be designers who engaged in arranging immersive displays for their curios and pieces of salvage. Some of the atmospheric rooms they created were rather casually conceived. In the studio of Mariano Fortuny y Marsal in Rome, the bric$\grave{a}$-brac coexisted side by side with valuable collectibles and some of them performed mundane

1 The content of the room is now at the British Museum as the Waddesdon Bequest; Pipa Shirley and Dora Thornton, eds., A Rothschild Renaissance: New Look at the Waddesdon Bequest in the British Museum (London: The Trustees of the British Museum, 2017); Ulrich Leben, "A High Victorian legacy at Waddesdon Manor: Baron Ferdinand's smoking room and its contents since the creation of Waddesdon," Journal of the History of Collections 27, no. 3 (November 2015): 335-45. functions. Fourteenth-century Alhambra jars serving as vases are an eloquent illustration. (Fig. 88) But arrangements could follow more sophisticated conventions. The Oriental and Renaissance galleries installed in Paris after 1881 by Jean-Léon Gérôme's brother-in-law, Albert Goupil, come to mind. Furnished respectively as a drawing-room and a bedroom, for visitors, the rooms evoked "practically living museums," through the quality, historicity, function and arrangement of the assembled objects. The installation involved creativity. Instead of carpeting the floor, Goupil's most sumptuous rugs were hung on the walls, as if canvases; because of their bright colours and iconography, they were said to compare favourably with European paintings. ${ }^{2}$ (Fig. 89 and 9o)

The decorative idea was taken a step further by collectors who delighted in architectural salvage, by inclination or opportunity. They were individuals who had the occasion to spend long periods of time in the Middle East, and notably in Egypt. The "style rooms"3 they created with historic fragments in Cairo accomplished more than providing atmosphere and individuality; they became the collectible itself. Diverse techniques were used to revive historic décors. Collectors turned to reuse and patina, as well as replica and revival; in most instances these were employed in combination. Whatever their flaws or artificiality,

2 Mercedes Volait, "Les intérieurs orientalistes du comte de Saint-Maurice et d'Albert Goupil: des 'Cluny arabe' au Caire et à Paris à la fin du XIX'e siècle," in The Period Rooms. Allestimenti storici tra arte, collezionismo e museologia, eds. Sandra Costa, Dominique Poulot, Mercedes Volait (Bologne: Bononia University Press, 2017), 103-14.

3 For the different types of historic rooms (style rooms, period rooms, epoch rooms), see Benno Schubiger, “Period Rooms' als museographische Gattung: 'Historische Zimmer' in Schweizer Museen," Zeitschrift für Schweizerische Archäologie und Kunstgeschichte 66, no. 2-3 (2009): 81-112 (82).

(C) MERCEDES VOLAIT, 2021 | DOI:10.1163/9789004449886_006

This is an open access chapter distributed under the terms of the CC BY-NC-ND 4 .o license. 


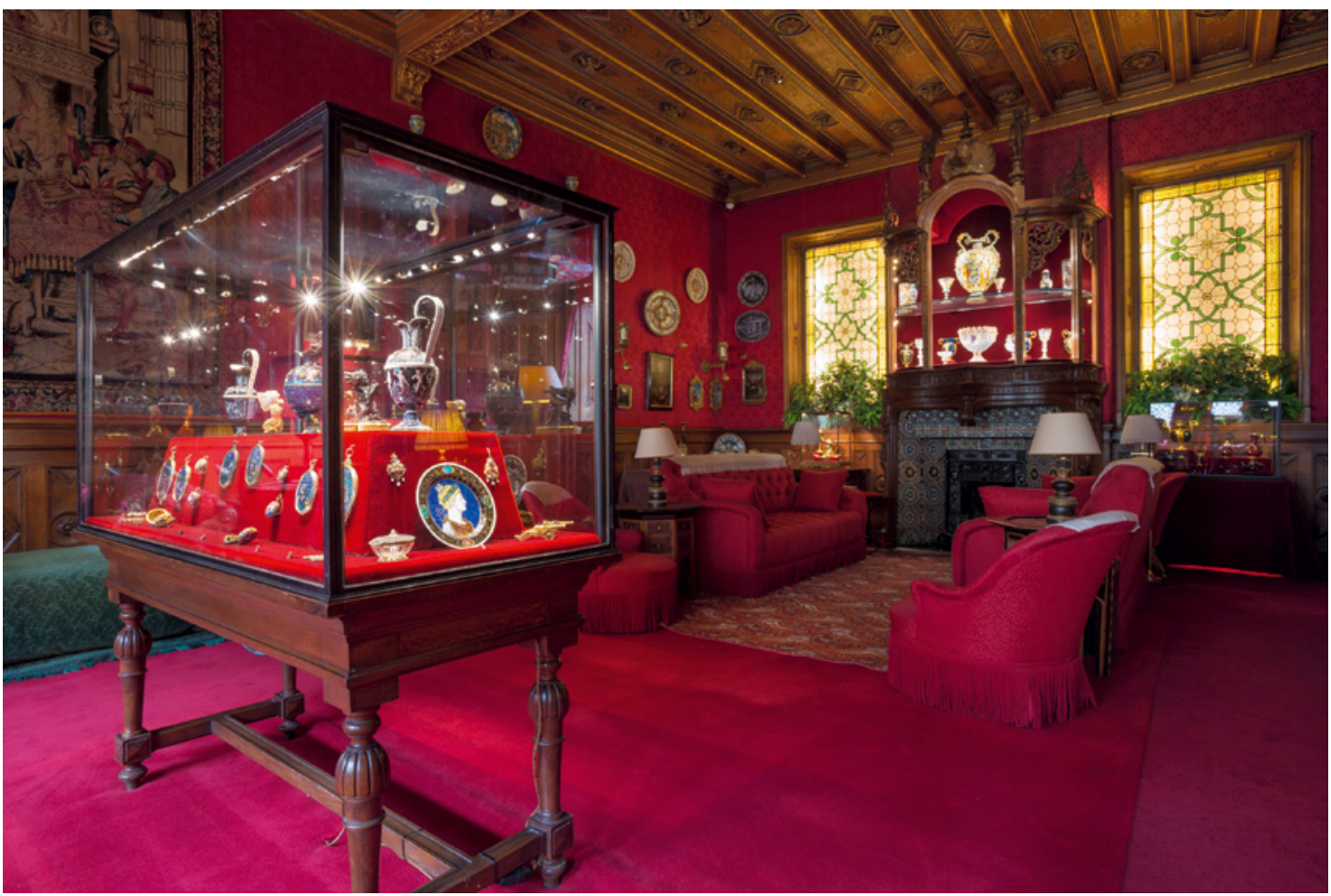

FIGURE 87 Ferdinand de Rothschild's 'Renaissance Museum' at Waddesdon Manor PHOTOGRAPH BY CHRIS LACEY/NATIONAL TRUST, WADDESDON MANOR, 2017

UN TEMPL. DEL A'BTE

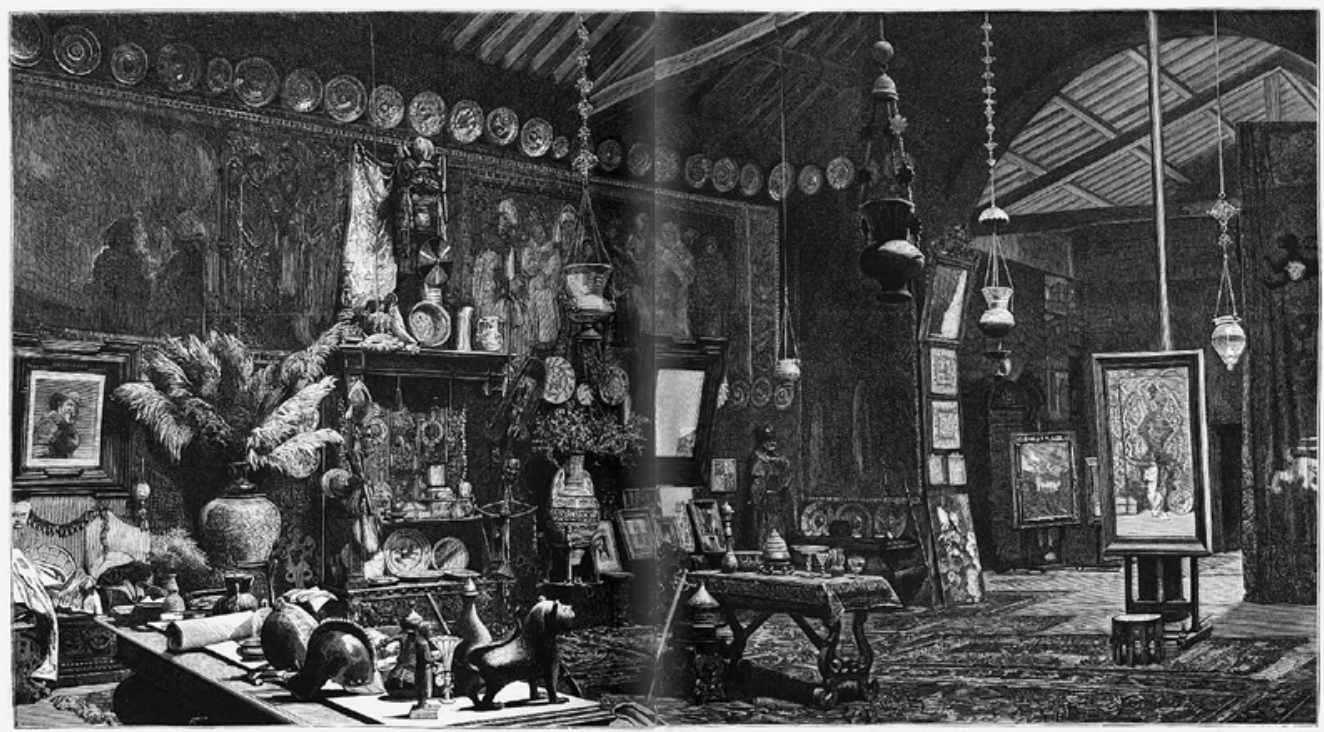

FIGURE 88 Interior del estudio de Fortuny, Roma [Interior of Mariano Fortuny y Marsal's studio in Rome, Italy]. Engraving

LA ILUSTRACIÓN ESPAÑOLA Y AMERICANA 19, SUPPLEMENT TO FASC. X, 15 MARCH 1875, 180-81 


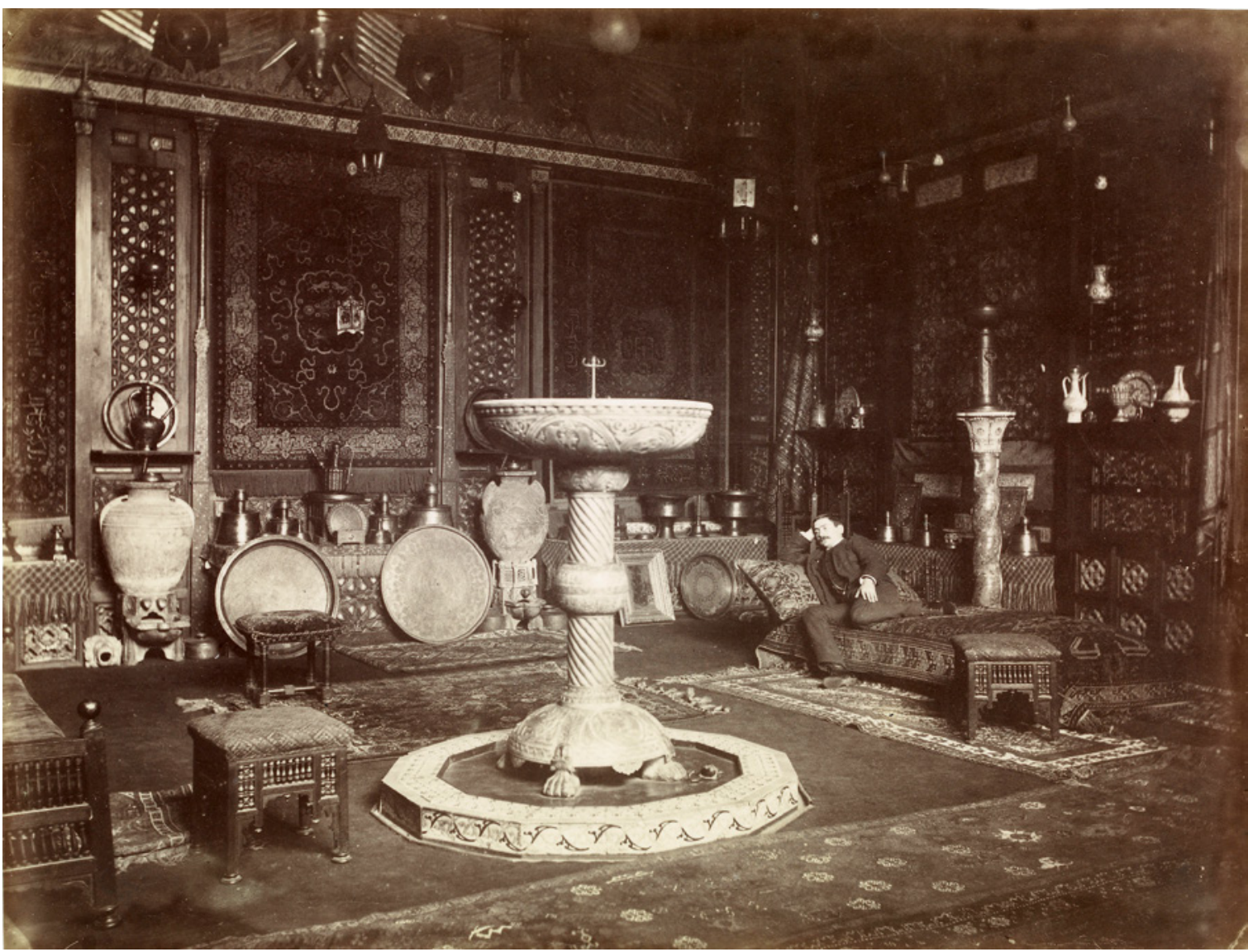

FIGURE 89 Edmond Bénard, Untitled [Albert Goupil's Oriental gallery at 9 Chaptal St., Paris, c. 1884-88]. The young man reclining on the sofa is his nephew Jean Gérôme. Albumen print. $20 \times 27.5 \mathrm{~cm}$ EDMOND BÉNARD, INTÉRIEURS PRIVÉS D'ARTISTES. ATELIERS D'ARTISTES, 1880-1910, F. 35. PARIS, BIBLIOTHÈQUE DE L'INHA, 4 PHOT 021

and irrespective of how we view them today, the attempts at recreating historic interiors discussed here, fit the model of Gesamtkunstwerks, i.e. total works of art in their own right.

The concept, and its Cairene manifestations, experienced various lives and afterlives. The phenomenon raises in turn a set of queries from the point of view of materiality and crosscultural interactions - the perspective that runs throughout this book. How did the modern art of accommodating architectural salvage, developed in Cairo by Western artists and patrons for the sake of Revivalism, work at a material level? Did it connect to the centuries-long Egyptian culture of reuse, or not? What impact, if any, did arrangements incorporating salvage have on subsequent Revival interiors, once the mass-market reproduction of themed rooms became accessible to the middle-class in the late nineteenth-century? The responses are not unequivocal.

\section{$1 \quad$ Atmospheric Interiors for Western Connoisseurs}

Many purchases of antiques in Cairo or Damascus during the 186 os-7os were connected to modern recreations of Middle Eastern architecture, whether at home or in the Middle East itself. Olana House, the family mansion designed in 


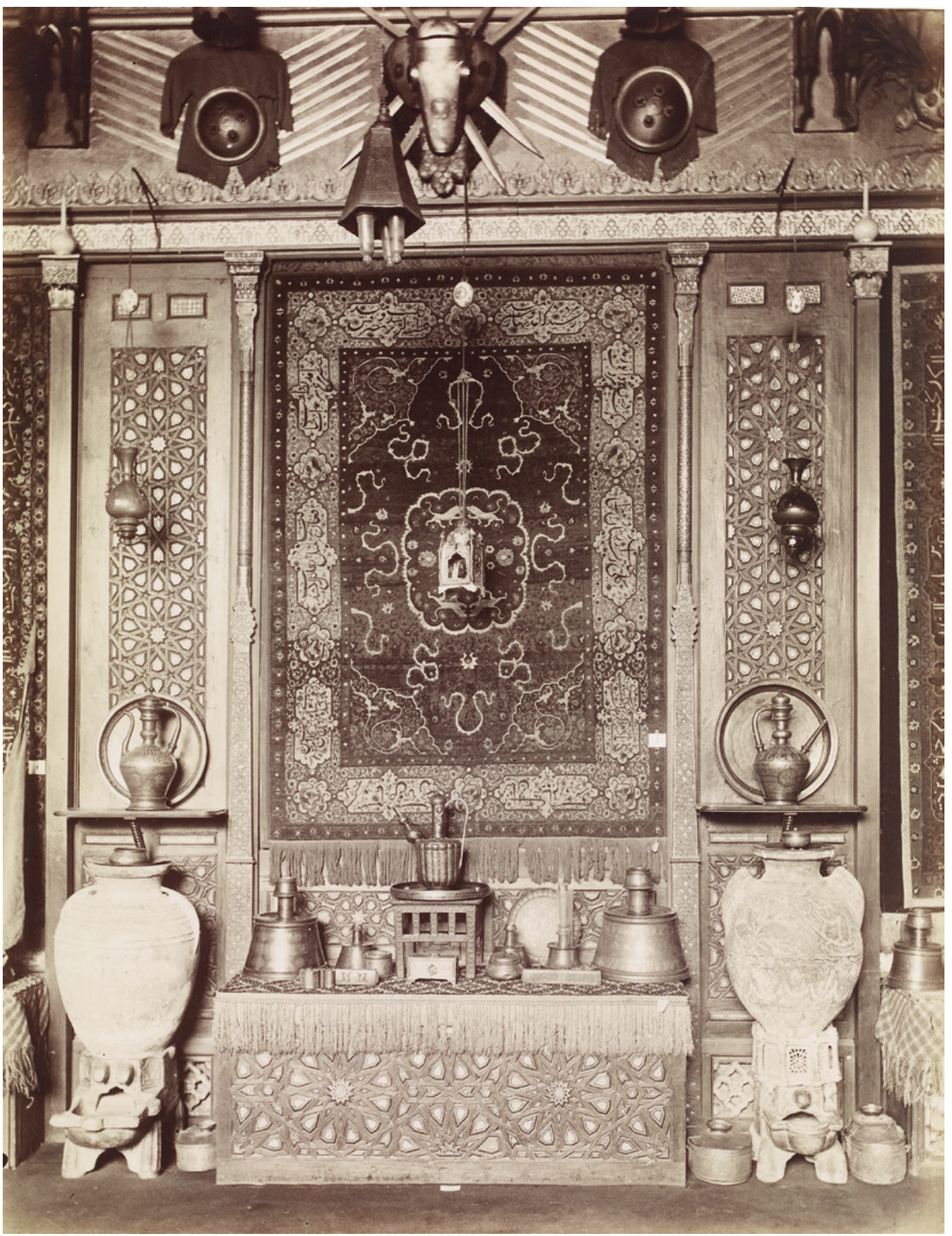

FIGURE 90 Edmond Bénard, Untitled [Medallion carpet displayed at Albert Goupil's Oriental gallery on 9 Chaptal St., Paris], c. $1884-88$. Albumen print. $26.9 \times 20 \mathrm{~cm}$ EDMOND BÉNARD, INTÉRIEURS PRIVÉS D'ARTISTES. ATELIERS D'ARTISTES, 1880-1910, F. 37. PARIS, BIBLIOTHÈQUE DE L'INHA, 4 PHOT 021 
upstate New York from 1871 onwards by Frederic Edwin Church, is an early example. It was conceived "after a pattern of a Damascus house," upon his return from a long journey to Europe and the Near East that took him and his family to Syria and Palestine from January to May 1868.4 Elements of recognisable Syrian origin contributed to the design and interior decoration of the house. Some of the valuables in Goupil's rooms may have shared an identical Syrian provenance; they were indeed most probably bought at the same time, possibly at Abu Antiqa. Albert Goupil's first encounter with Islamic artworks took place during his travels through the Arab provinces of the Ottoman Empire in January-June 1868 with a group of artists; the caravan was led by his brother-in-law Jean-Léon Gérôme. ${ }^{5}$ The party crossed paths with the Churches twice, at Jerusalem on 3 April 1868 and in Damascus on 2 May 1868. Since one of the artists of the French group, Famars Testas did produce several sketches during two afternoons at "Abou Antiquas,"6 it is safe to assume that the famous antique dealer and his treasures were familiar to all of them. Another possible customer of Abu Antiqa, in person or in absentia, was Gaston de Saint-Maurice, the patron of a remarkable "modern Arabic Palace" built in Cairo in 187279. As we shall see, some architectural fragments connect his endeavour to Damascus.

\subsection{A Damascene Home Up the Hudson: Olana House and the Mediation of Christianity}

Church is reputed to have brought back thousands of "trophies of travel"7 from his Grand

4 Marianne North, Recollections of a Happy Life (London, 1894), 1:67; Mercedes Volait, "Olana, A Persian-style home for the enjoyment of fine architecture", in Frederic Edwin Church: A Painter's Pilgrimage, ed. Kenneth Myers (Detroit: Detroit Institute of arts, 2017), 192-207.

5 Jean-Louis Andral et al., eds., Album de voyage: Des artistes en expédition au pays du Levant (Paris: AFAA/RMN, 1993).

6 Andral, Album de voyage, 181-84.

7 Boston Daily Evening Transcript, 3 December 1869, 2.
Tour overseas. The valuables ranged from "stones coming from the ancient sites of Petra and the Parthenon to coloured-stone architectural fragments from a house in Damascus, rugs, Ottoman embroidery, Arab spears and armors, and mere tourist curios." ${ }^{8}$ Among them, was a sixteenthcentury thirty-two-tile panel installed in the vestibule of the front porch at Olana. (Fig. 91) Featuring a vase flanked by two cypresses, the panel is typical of the Iznik-style ceramics produced in Ottoman Damascus. Both the tones of the glazes - turquoise, olive green, blue and manganese over a white ground - and the design - floral sprays rising from a vase decorated with prunus flowers - are characteristic of that type of production. ${ }^{9}$ Placed in central positions on walls or in niches, tile panels decorated the main rooms in Syrian architecture, domestic and religious alike. ${ }^{10}$

A close look at the panel shows that it had been both mended and filled with spare tiles to replace missing parts and it may even have been formed out of several incomplete sets. Full specimens were probably very rare. In 1871, British diplomat Richard Burton reported to the artist and Syrian-tile collector Frederic Leighton that "he was willing to have a house pulled down for [him], but the difficulty is to find a house with tiles."11 The cannibalisation of tiles had already been going on for some time in Damascus.

As a whole, Olana reflects the Churches' exposure to Damascene houses. The brilliance of their

Hudson (US), Olana New York State Historic Site, Estate of Sally Church Papers, Frederic Church to William Osborn, 4 February 1869, transcript of a lost original, quoted in Zukowski, Historic Furnishings, 58. Anne-Claire Schumacher, ed., Terres d'Islam. Les collections de céramique moyen-orientale du Musée Ariana à Genève (Milan: 5 Continents, 2014), exhibition catalogue, 3o6-12.

10 Brigid Keenan, Damascus: Hidden Treasures of the Old City (London: Thames and Hudson, 200o), 54 sq.

11 London, Leighton House, Sir Richard Francis Burton in Damascus to Frederic Leighton, 22 March 1871, $\mathrm{LH} / 1 / 5 / 24$. 


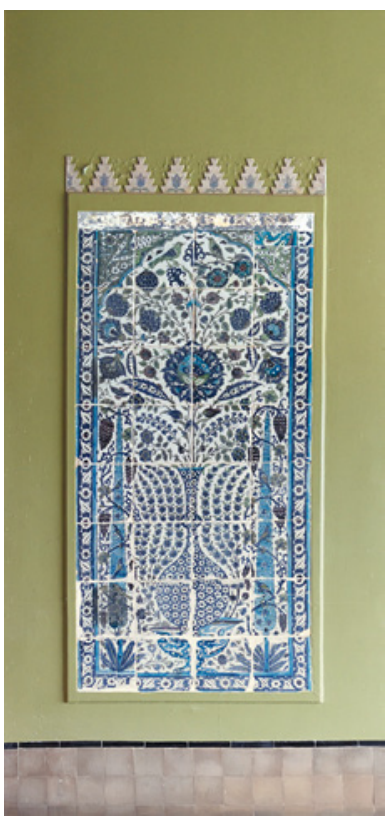

FIGURE 91 Damascene tile-panel in the front porch at Olana House, Hudson, Greenport, near Hudson, NY, USA

PHOTOGRAPH BY GERALD CARR, 2016

polychromatic interior decoration was legendary. ${ }^{12}$ All visitors to the "oldest city in the world," as the Syrian capital was then coined, ${ }^{13}$ concurred that "the chief glory of Damascus is in the splendor of its private houses." ${ }^{14}$ Reception chambers were either decorated with panels of marble revetment or colourful paste-work designs inlaid into stone,

12 John Dibblee Crace, "On the Ornamental Features of Arabic Architecture in Egypt and Syria," Sessional Papers of the RIBA (1870): 71-90.

13 Josias Leslie Porter, The Giant Cities of Bashan and Syria's Holy Places (New York: T. Nelson, 1867), 336. The same statement appears twice in Mark Twain, The Innocents Abroad, or The New Pilgrims' Progress ... With Two Hundred and Thirty-Four Illustrations (Hartford: American publishing company, 1869), 457, 651: 'Damascus, the 'Pearl of the East,' the pride of Syria, the fabled Garden of Eden, the home of princes and genii of the Arabian Nights, the oldest metropolis on earth...."

14 Josias Leslie Porter, Five Years in Damascus: Including an Account of the History, Topography, and Antiquities of that City; with Travels and Researches in Palmyra, Lebanon, and the Hauran (London, 1855), 33. or with elaborate painted woodwork. Recurrent themes were motifs from nature, such as flowerfilled vases and overflowing fruit bowls, all symbols of botanical opulence. This characteristic perfectly suited Frederic Church, a landscape artist who attached great value to nature and gardening. Olana was conceived with a central hall recalling the Damascene courtyard - the room was intended to be domed, but ultimately was not. (Fig. 92)

That Olana was recurrently deemed "Persian in style" at the time is only seemingly contradictory. ${ }^{15}$ At that point, "Persian-ness" in matters of art denoted a style, not a land or a country. Iznik tiles, produced in Turkey, were long deemed "Persian" because of their floral pattern - the Iznik provenance was a late recognition. Floral Damascene tiles were also labeled "Persian" along the same rationale. ${ }^{16}$ The comment made in 1870 by John Dibblee Crace (already quoted in Chapter 3 ) that the interior polychrome decoration in Damascus was "of essentially Persian character" meant, in a similar way, that it was primarily floral. ${ }^{17}$ Just as "Arab," by contrast, had come to symbolise geometry, 18 "Persian" was now equated with floral "Arabesque," that is, vegetal ornament. ${ }^{19} \mathrm{~A}$ "Persian room" (called as such in Damascus, i.e. 'ajamī) did not designate a room from or in Persia, but one

\footnotetext{
15 For a discussion, Volait, "Olana."

16 For the confusion between Persian, Rhodian, Damascus, and Iznik tiles, see Arthur Lane, "The Ottoman Pottery of Isnik," Ars Orientalis 2 (1957): 24781, and for a contemporary review of shifting attributions, Julian Raby, "Iznik, The European Perspective," in Nurhan Atasoy and Julian Raby, Iznik:The Pottery of Ottoman Turkey (London: Alexandria Press, 1989), 71-4. 17 Crace, "On the Ornamental Features."

18 As argued by French architect Eugène Viollet-le-Duc in his introduction to Jules Bourgoin's Les Arts arabes, Architecture, menuiserie, etc. avec une table descriptive et explicative et le trait general de l'art arabe (Paris: A. Morel, 1868-73), 6-9.

19 On changing understandings of ornament across time and geography and on cross-cultural fertilization, Gülru Necipoğlu and Alina Payne, eds., Histories of Ornament: From Global to Local (Princeton: Princeton University Press, 2016).
} 


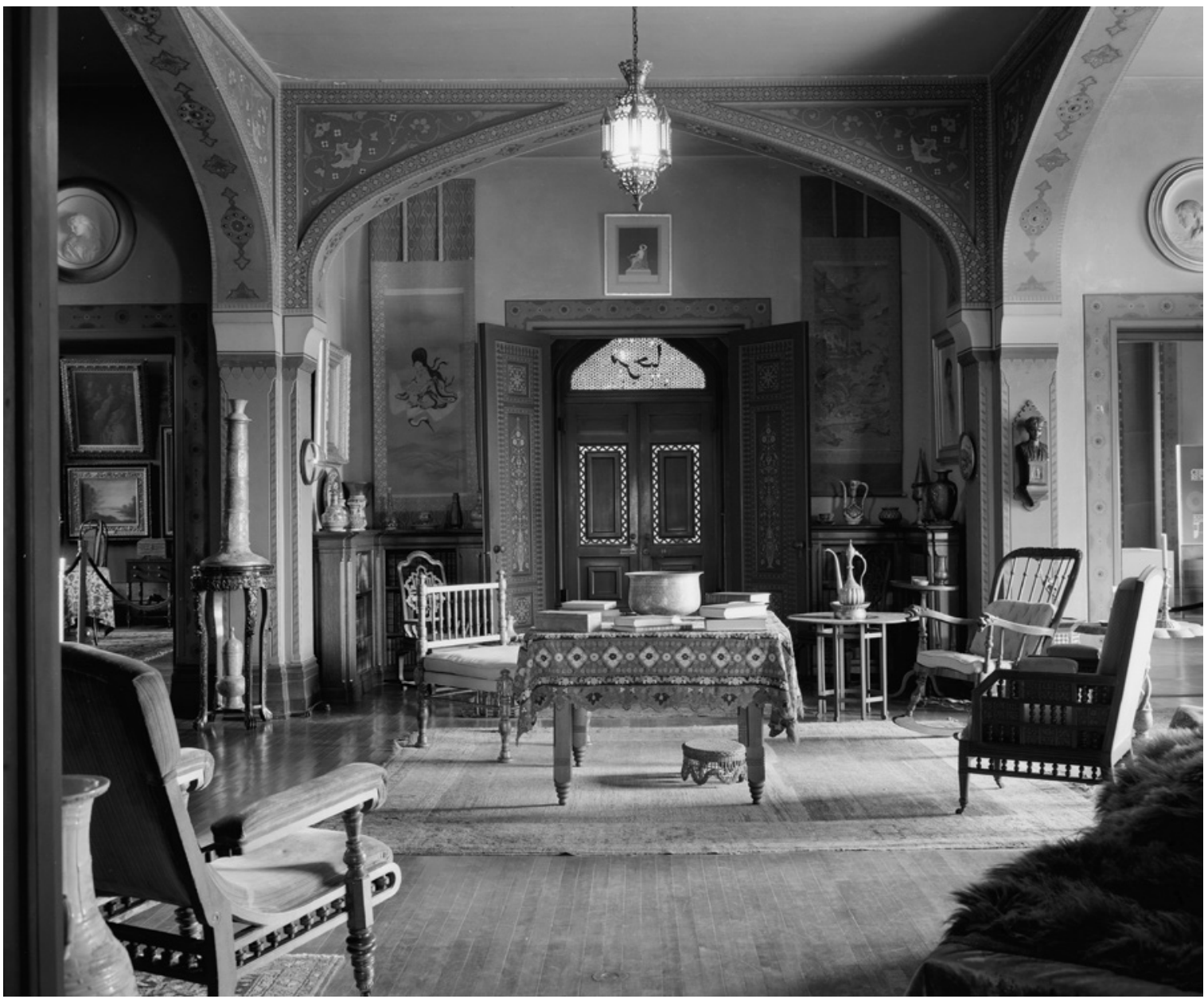

FIGURE 92 Cervin Robinson, Olana court hall looking toward the main entrance, 1969. From $10.16 \times 12.7 \mathrm{~cm}$ negative WASHINGTON, DC, LIBRARY OF CONGRESS, HISTORIC AMERICAN BUILDINGS SURVEY, NY-5501-12

ornamented in gesso relief with fruit and flower paintings. $^{20}$

What Church brought back from Syria and Palestine, more unexpectedly, were reminiscences of Eastern Christianity. The mantel over the fireplace in the sitting room bears an Arabic inscription taken from a biblical verse: "While I was musing, the fire burned" [عند لهبي اشتعلت النار, inda lahaji, ishtáalat al-nār] (Ps. 39:3). (Fig. 93) It is both a literal allusion to the flames beneath it

20 Anke Scharrahs, Damascene 'Ajami Rooms: Forgotten Jewels of Interior Design (London: Archetype Publications, 2013). and an indirect reference to the fragility and vanity of human life, recalled in the subsequent lines of the Psalm. The fragment resonates with Eastern Christianity as well as Western missionary work in the Levant. The circle of acquaintances of the Churches during their stay in the Holy Land was mainly composed of British, Irish, and American missionaries, ${ }^{21}$ including Dr. Cornelius Van Dyck

21 John Davis, "Frederic Church's late career," in Davis, The Landscape of History: Encountering the Holy Land in Nineteenth-Century American Art and Culture (Princeton, N.J.: Princeton University Press, 1996), 168-207. 


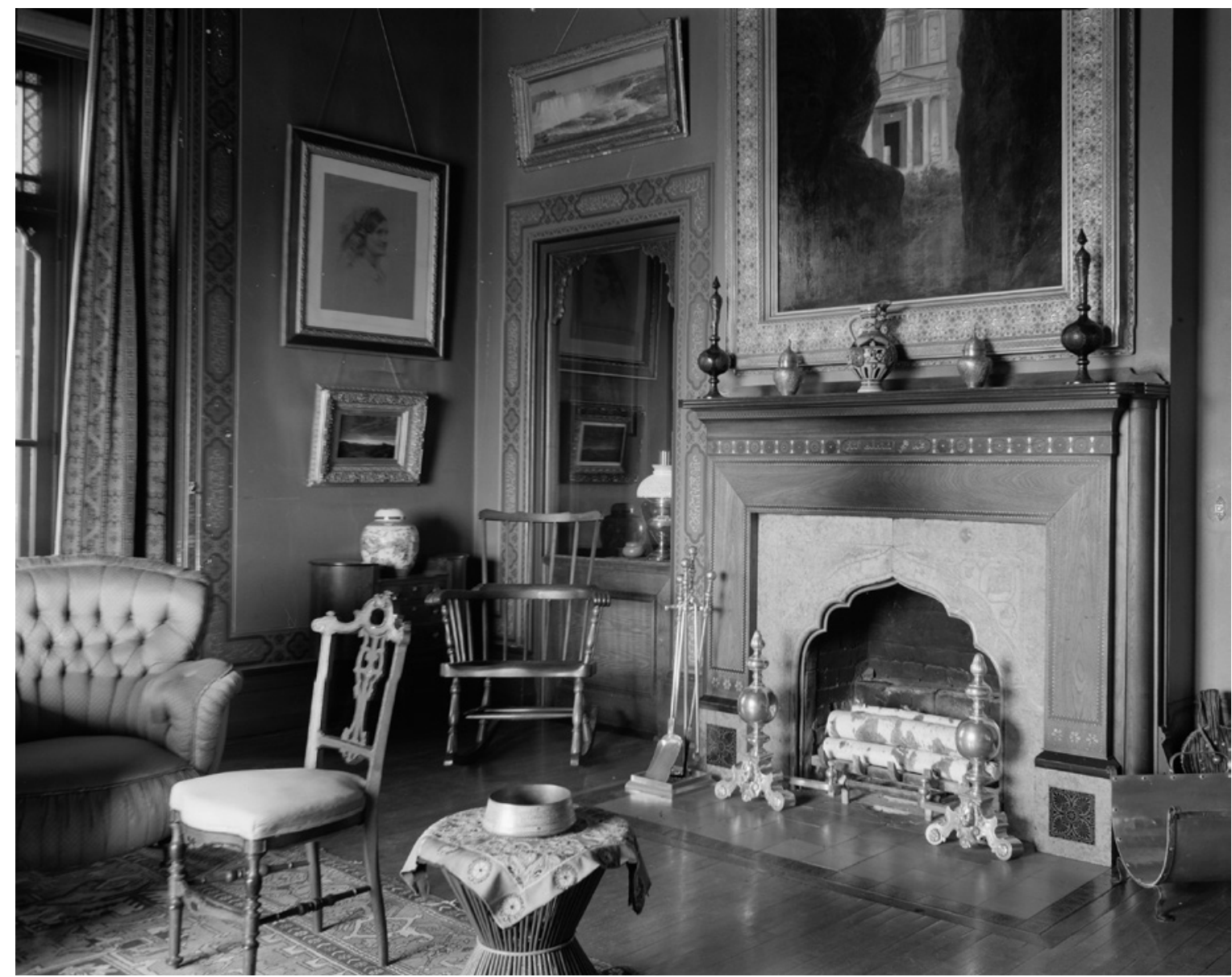

FIGURE 93 Cervin Robinson, Sitting room at Olana house, 1969. The fire-place bears an Arabic inscription. From $10.16 \times 12.7 \mathrm{~cm}$ negative

WASHINGTON, DC, LIBRARY OF CONGRESS, HISTORIC AMERICAN BUILDINGS SURVEY, NY-5501-16

(1818-95), the main force behind a new translation of the Bible into Arabic funded by the American Bible Society - "truly a noble work," in the very words of Church's wife. ${ }^{22}$ The couple would have heard of the July 1860 massacres in Damascus, in which about 2,00o Christian inhabitants of the city were killed and their houses burnt, as well as the school of the Presbyterian mission. Quoting from the Bible in Arabic was a way to connect to

22 New York Historical Society, Isabel Church diary, 1868; quoted in Karen Zukowsky, Historic Furnishings Report For Olana state Historic Site, A History of the Interiors, Thoughts on their Significance, and Recommendations for Their Restoration (Hudson, NY: Olana State Historic Site, 2001), 382 . early Christianity. For the stenciling on a doubledoor in the same room, Church chose a motif deriving from an Armenian church in Jerusalem, based on a plate by Jules Bourgoin, Porte de l'église de Saint-Jacques des Arméniens à Jérusalem. ${ }^{23}$ (Fig. 94) The large Greek crosses adorning the façades of the bell tower, as well as the doors of the east parlour, provide another direct visual link to Near Eastern Christianity. (Fig. 95) In contrast with the usual association of the Islamic Revival

23 Jules Bourgoin, Les Arts arabes, pl. 27. 


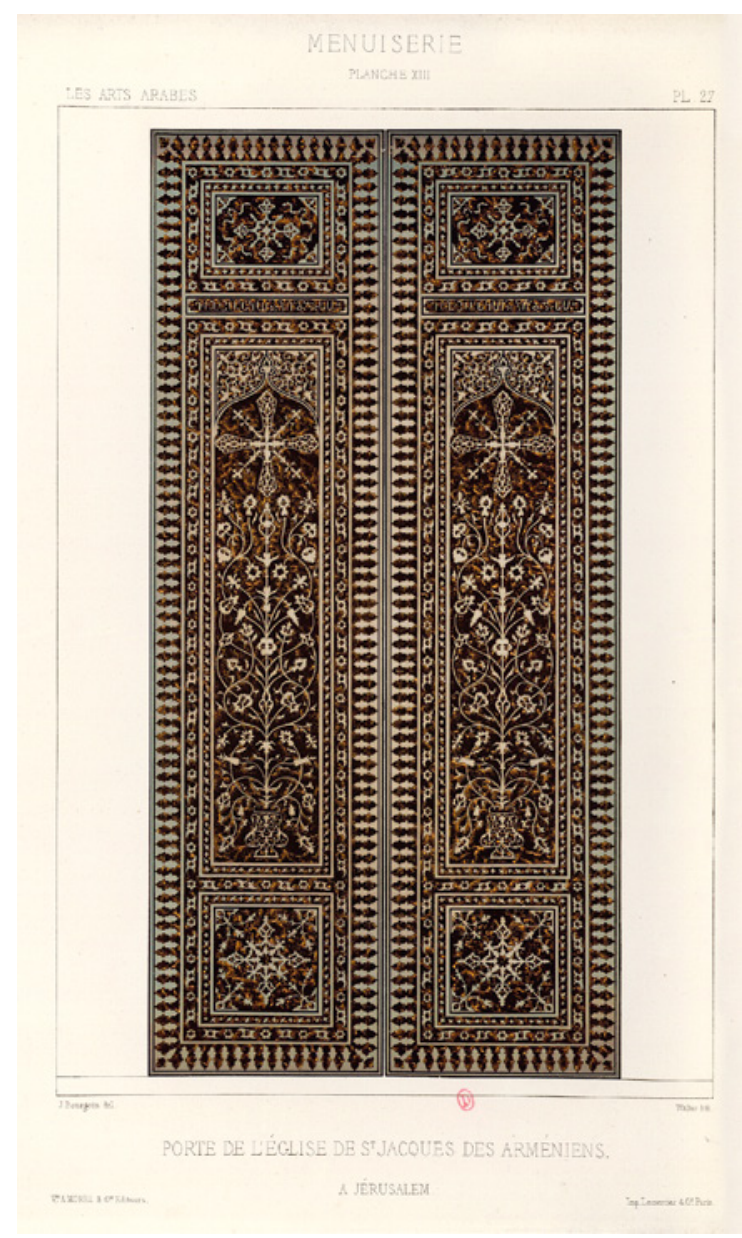

FIGURE 94 Jules Bourgoin, Porte de l'église de Saint-Jacques des Arméniens à Jérusalem. The drawing was emulated through a stenciled design for one of the doors at Olana House

LES ARTS ARABES, 1867-73: PL. 27

style with Islamophilia, ${ }^{24}$ Olana House highlights a connection to the region mediated by Christianity.

\section{$1.2 \quad$ Accommodating Christian Salvage in Cairo}

Local Christianity also surfaces in the ambitious "Modern Arab" house erected by Count Gaston de Saint-Maurice in Cairo's new quarters, while he was serving as Khedive Ismail's grand equerry

24 Rémi Labrusse, Islamophilies: l'Europe moderne et les arts de l'Islam (Paris: Somogy, 2011). from 1868 to 1878 . (Fig. 96 and 97) The man is known to have been a keen collector of Islamic artefacts. A large part of his collection was displayed in Paris at L'Égypte des Khalifes, the show he curated on the occasion of the Universal exposition of 1878 ; around 400 objects among the exhibits were ultimately purchased by the Victoria and Albert Museum. ${ }^{25}$ His Cairo's residence, facing the city's newly-built hippodrome, was meant to be a recreation of local historic architecture. In his very words dated 1882, the mansion was built:

Sur un plan ancien, avec des matériaux provenant des plus belles habitations des XIV ${ }^{\mathrm{e}}$, $\mathrm{XV}^{\mathrm{e}}$ et $\mathrm{XVI}^{\mathrm{e}}$ siècles. Plafonds sculptés peints et dorés, mosaïques de marbre et de nacre, portes de bronze et d'ivoire, faïences de Perse et du Caire, moucharabiehs, inscriptions, moulages, etc., etc. ${ }^{26}$

In other words, Saint-Maurice's approach consisted of fitting and repurposing period materials into a new construction, with the intention of emulating historic architecture. It was an exercise in reuse, in the accommodation of salvage. The house was depicted then as "an exemplary Arab restoration," for this is how "restoration" was understood at the time. ${ }^{27}$

25 Moya Carey and Mercedes Volait, "Framing 'Islamic Art' for Aesthetic Interiors: Revisiting the 1878 Paris Exhibition," International Journal of Islamic Architecture 9, no. 1 (2020): 31-59 [doi: 10.1386/ijia_oooo3_1]; a study of the collection by Moya Carey and myself is under preparation.

26 London, Victoria and Albert Archive, Gaston de Saint-Maurice Nominal file, MA/1/S18o, Gaston de Saint-Maurice to Philip Cunliffe-Owen, 24 October 1882: "built according to an ancient plan, with materials coming from the most beautiful houses of the 14th-, 15th- and 16th-century, [with] sculpted ceilings, painted and gilded, mosaics of marble and mother-ofpearl, doors in bronze and ivory, Persian and Cairene tiles, mashrabiyas, inscriptions, plaster casts, etc. etc." [My translation].

27 Gabriel Charmes, "Lart arabe au Caire," Journal des débats, 2, 3 and 4 August 1881, 54. 


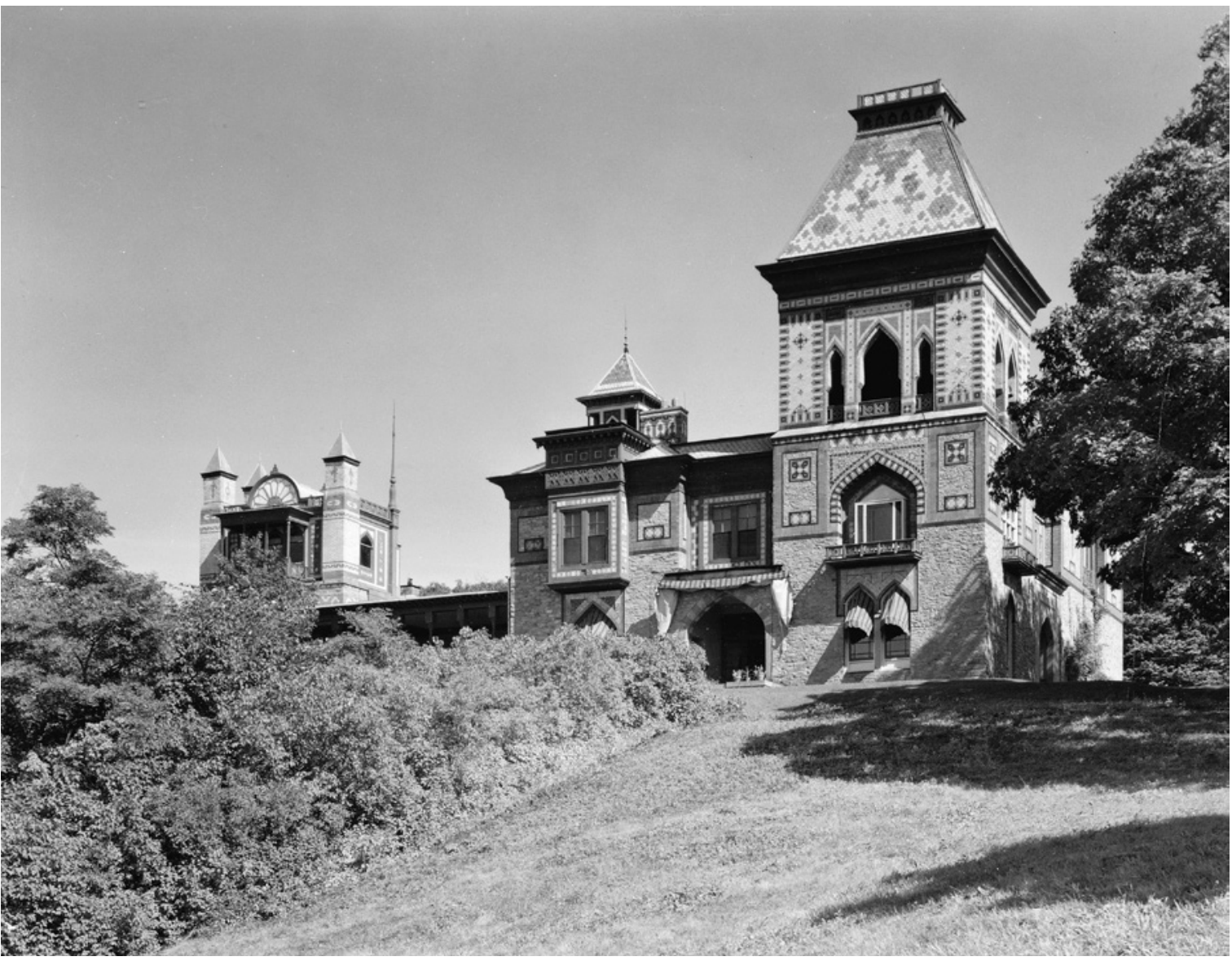

FIGURE 95 Cervin Robinson, General view of Olana House from south west, 1969 . From $10.16 \times 12.7 \mathrm{~cm}$ negative WASHINGTON, DC, LIBRARY OF CONGRESS, HISTORIC AMERICAN BUILDINGS SURVEY, HABS NY-5501-1

The endeavour took seven years to be completed. Like many high officials at the Khedivial court, the French aristocrat had been granted a land in suburban Cairo for his residence in 1872 ; the foundation inscription, penned in Arabic around the ceiling of the house's central hall, stated that it was finished in $1296 \mathrm{AH} / 1879 \mathrm{AD}{ }^{28}$ (See below Fig. 121) A few years later, the house was offered for sale and the premises were bought by the French Ministry of Foreign Affairs for diplomatic use.

28 For a history of its construction, Mercedes Volait, Maisons de France au Caire: le remploi de grands décors mamelouks et ottomans dans une architecture moderne (Cairo: Publications de l'Institut français d'archéologie orientale, 2012). The initial house stood on Sherif Street.
Although the house was ultimately dismantled in 1937, its interiors were partially salvaged a second time, on the recommendation of Gaston Wiet, who then headed Cairo's "Musée Arabe" (presently Museum of Islamic Art). While considering some rooms of dubious taste, Wiet reckoned that the building was one of the most popular in Cairo, and that part of what it contained was of true archaeological value. ${ }^{29}$ A number of the secondhand interiors were hence reinstalled, with some adjustment, in the new premises acquired for the French diplomatic mission in Giza. Therefore,

29 Nantes, Archives rapatriées des postes, Le Caire, Ambassade, 353PO/2/404, Assessment by Gaston Wiet dated 25 February 1935 . 


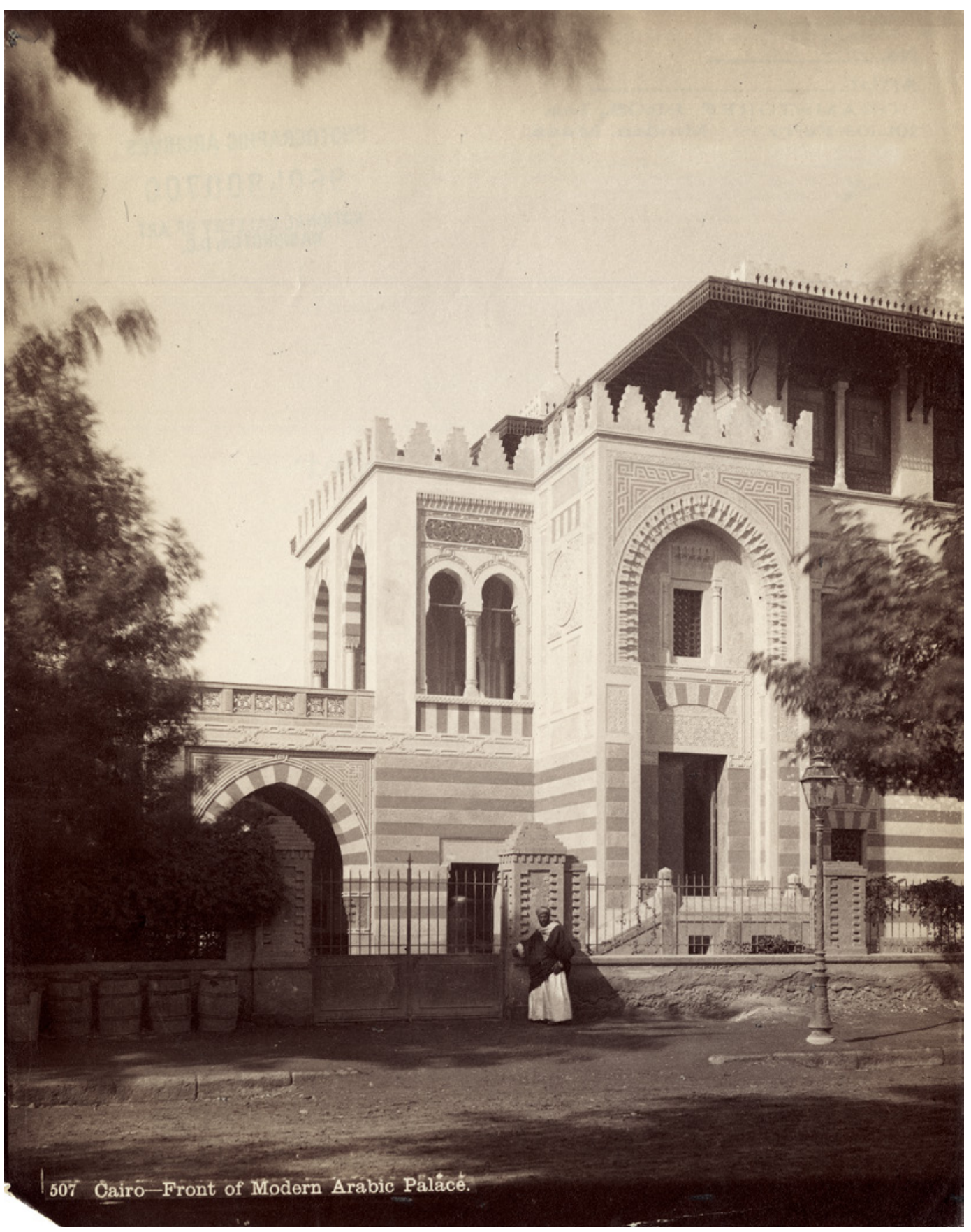

FIGURE 96 Edward Livingston Wilson, Front of Modern Arabic Palace. Cairo [Main entrance to the house of Gaston de Saint-Maurice in Cairo], 1882. Albumen print. $20 \times 25 \mathrm{~cm}$ WASHINGTON, DC, NATIONAL GALLERY OF ART PHOTOGRAPHIC ARCHIVES, GRAMSTORFF COLLECTION, 2512-A 


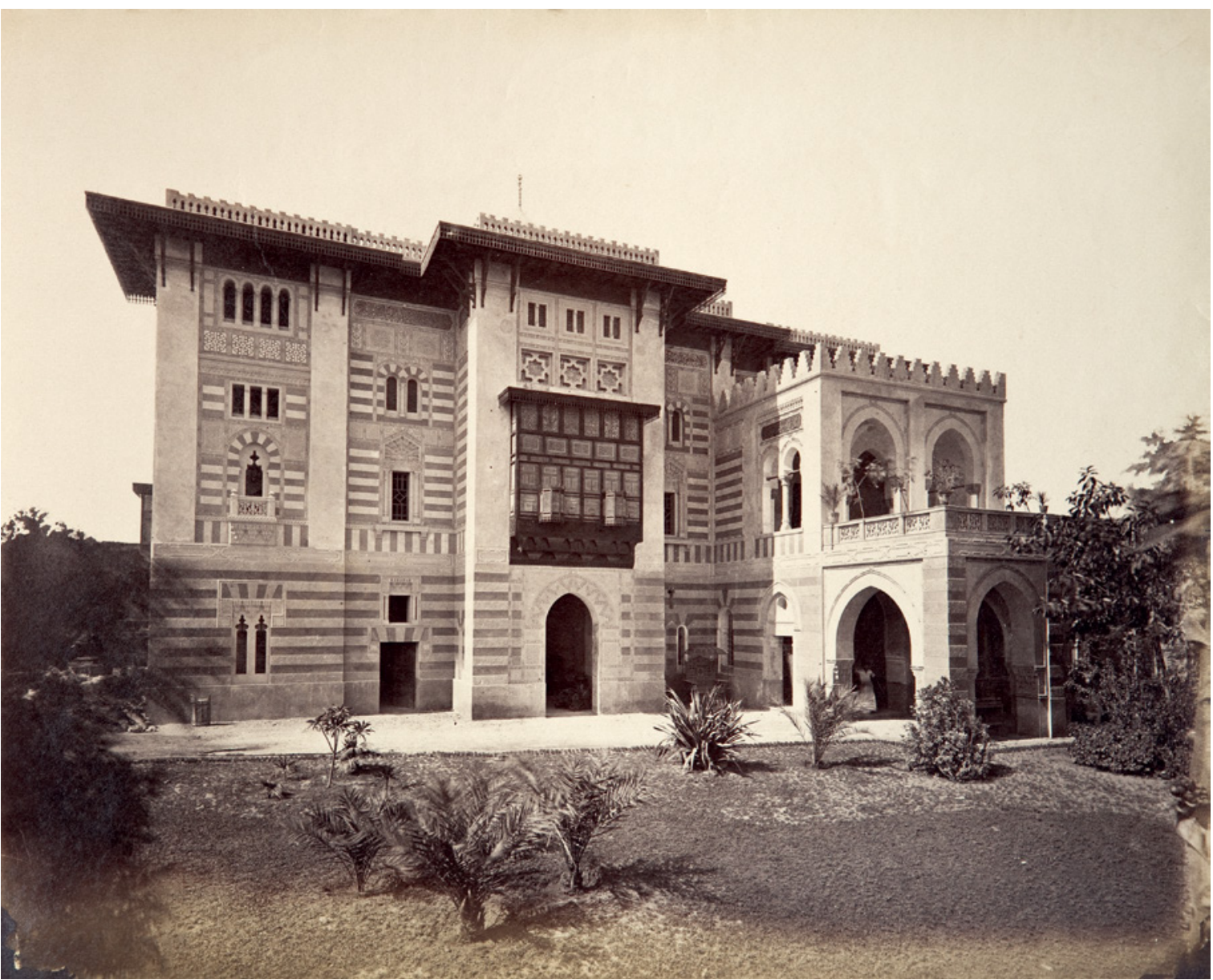

FIGURE 97 Beniamino Facchinelli, Casa del Conte Saint-Maurice costruita tutta in pezzi e modelli antichi sull'architettura araba (Cairo). Façade of the Saint-Maurice house from the garden. Mounted albumen print. $26 \times 20 \mathrm{~cm}$. Raccolta artistica di fotografie sull'architettura araba, ornati ecc. dal XII ${ }^{\circ}$ al XIII ${ }^{\circ}$ secolo fotografia italiana del Cav. B. Facchinelli, Cairo (Egitto), MDXXXLXXXVII [sic: XXX for CCC, soit 1887], f. 67 PARIS, BIBLIOTHÈQUE DE L'INHA, FOL PHOT 65

Saint-Maurice's achievement can still be partially observed first hand.

The pieces of salvage included a couple of prestigious bronze doors. The entrance door (Fig. 98) was recognised by epigraphist Max van Berchem (1863-1921) as coming from the madrasa founded by Baybars I in the heart of Historic Cairo. A second, smaller bronze door at the house can be ascribed to the same building. The madrasa was demolished in 1874 to make room for a new street. The salvaged door bore the name of the sultan, besides a date written in numerals, that van Berchem suspected was a later addition, possibly at the hands of the dealer who procured the door. ${ }^{30}$

The most iconic part of the house was the cruciform hall located on the first floor. Its plan was inspired by the typical $q \bar{a}^{c} a$ of Mamluk and Ottoman houses in Cairo, the reception room with

$30 \quad$ Max van Berchem, "Matériaux pour un corpus Inscriptionum Arabicarum, Égypte première partie," Mémoires publiés par les membres de la mission archéologique française XIX (1894): 120. 


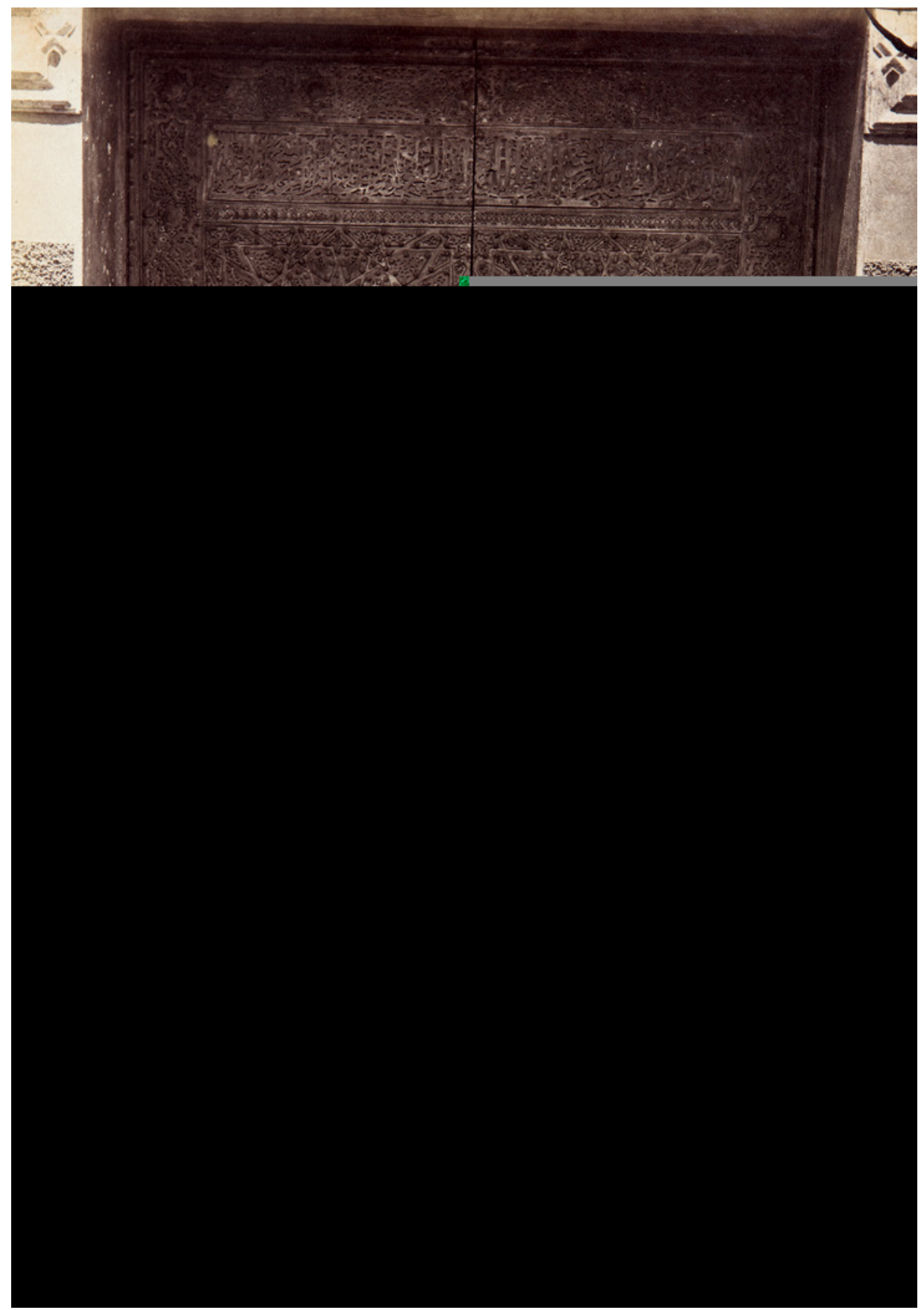

FIGURE 98 Beniamino Facchinelli, Porta in Bronzo (Cte St Mce). Historic bronze door at the entrance of Saint-Maurice house in Cairo; the date $661 \mathrm{H}$ (1262-63 AD) in numerals was added during its restoration. Mounted albumen print. $19 \times 26 \mathrm{~cm}$. Raccolta artistica di fotografie sull'architettura araba, ornati ecc. dal XII ${ }^{\circ}$ al XIII ${ }^{\circ}$ secolo fotografia italiana del Cav. B. Facchinelli, Cairo (Egitto), MDXXXLXXXVII [sic: XXX for CCC, soit 1887], f. 93 PARIS, BIBLIOTHÈQUE DE L'INHA, FOL PHOT 65 


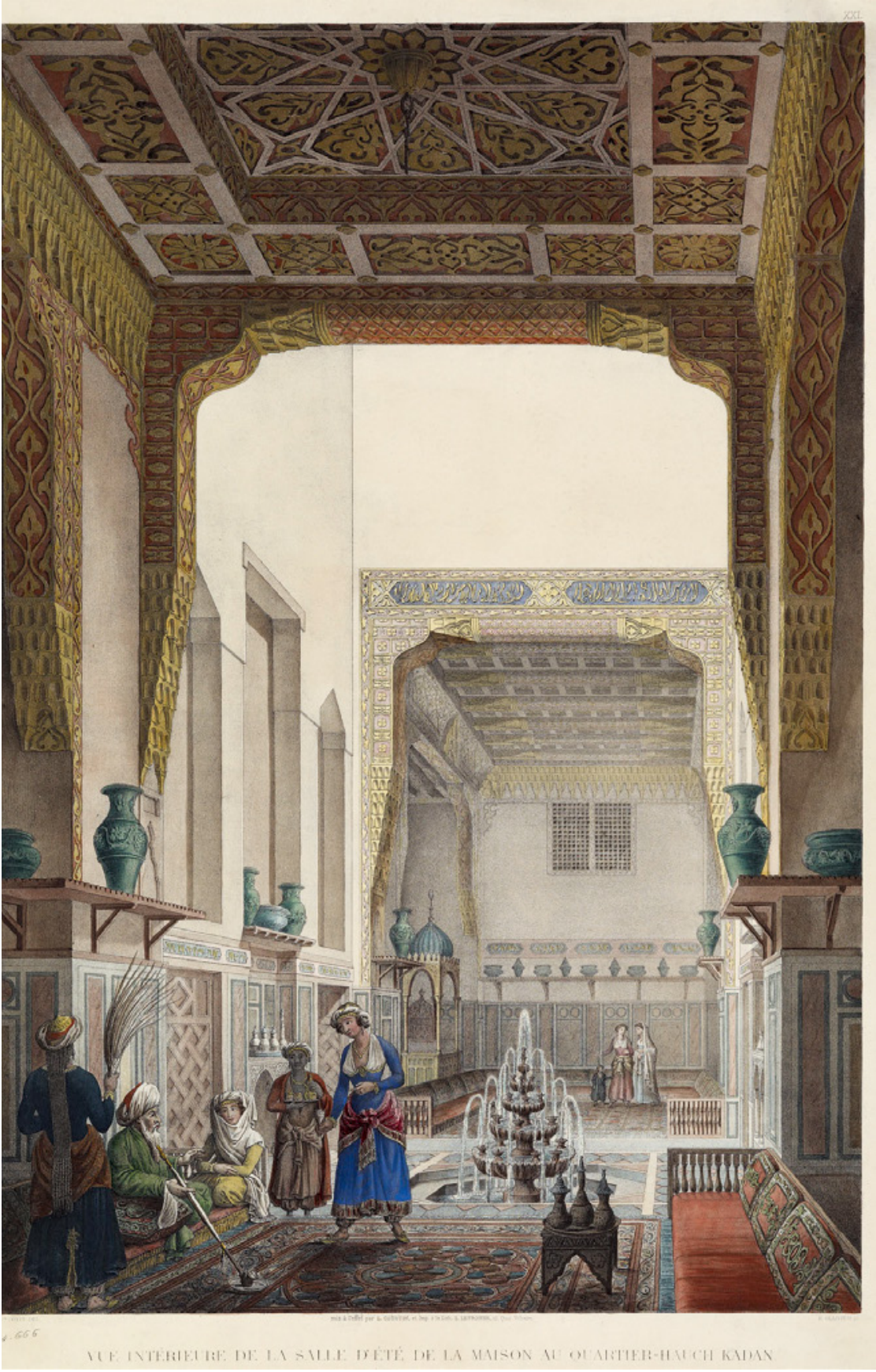

FIGURE 99

Pascal Coste, Vue intérieure de la salle d'été de la maison au quartier Hauch Kadan. Interior view of a $q \bar{a}^{c} a$ in Cairo, Chromolithograph published as pl. XXI in unidentified publication. $48.4 \times 31.7 \mathrm{~cm}$ CHARENTON-LE-PONT, MÉDIATHÈQUE DE L'ARCHITECTURE ET DU PATRIMOINE, APMFO114666

high ceilings, lit by a central lantern. These rooms captivated European travellers; they were seen as characteristic of Cairo. Detailed views of such spaces were produced during the French occupation of Egypt in 1798-1801. Later, architect Pascal Coste included an illustration in his own survey of
Cairene architecture. ${ }^{31}$ (Fig. 99) In Saint-Maurice's version, the recesses were given extra depth and

31 Pascal Coste, Architecture arabe, ou Monuments du Kaire, mesurés et dessinés, de 1818 à 1826 (Paris: FirminDidot, 1837-39), pl. XLVI. 
a large lattice window was installed in one of them to convey additional light. (Fig. 100 and 101) Significantly, the room incorporated the typical shelf placed at mid-height to display wares of various kinds; instead of them being showcased in a display cabinet, as was usual at the British and Austrian Rothschilds for instance, Saint-Maurice's collectibles were presented as objects of daily use. Each recess received an elaborate painted ceiling, distinct from one another in style and relief. The central ceiling exhibited a rich pattern based on an eight-pointed star, formed from overlaid squares and filled with intricate arabesques; they were grouped in modules of four, interlocking with crosses presenting arms of equal length and pointed ends. (Fig. 102) The floor and dados were made of polychromatic stone mosaic dateable to the seventeenth or eighteenth century. Some doors presented inlaid historic panels characteristic of the Mamluk period that were repurposed within modern frames. (Fig. 103)

Several features of the hall relate to Eastern Christianity. The most evident one is nestled up in an Arabic inscription circling one of the ceilings, about seven-metre height, which explains why it was only recently read. ${ }^{32}$ The inscription offers a variation of Psalm 150 (1-6), the final prayer in the Book of Psalms, known as the Musicians' Psalm, as it names nine types of musical instruments called to praise God. The verses are familiar to any Christian Egyptian because they are chanted during the Eucharist portion of the Coptic liturgy.33 The scripture also echoes the function of the reconstructed reception hall, for it was used initially as a place for musical entertainment. Similarly to the biblical verse that literally alludes to the chimney it adorns at Olana House, a psalm naming musical instruments decorated the cornice of a reception hall where music was occasionally performed, suggesting that inscribed texts were selected on purpose and have to be understood literally.

\footnotetext{
32 Mercedes Volait, Maisons de France, 200-02.

33 The psalm is known as the Communion Psalm, Abraam D. Sleman, St. Basil Liturgy, Reference book, 127.
}

The presence of biblical verses, used in the Coptic Orthodox liturgy, in Saint-Maurice's main hall suggests that at least one ceiling was salvaged from a Coptic building. Furthermore, a door in the same room bears a pattern of repeated crosses. (Fig. 104) Drawings by a French artist related to the Saint-Maurice house are annotated with the handwritten mention "Kasr Roumi" [qașrrūmī $],{ }^{34}$ which points again to a possibly Christian site. "Roumi" $[r \bar{m} m \bar{\imath}]$ is an adjective with ample semantic scope, as historian Cemal Kafadar has highlighted. ${ }^{35}$ The classical meaning is "Byzantine," and in principle designates all inhabitants of the central provinces of the Ottoman Empire, Anatolia and Rumelia. ${ }^{36}$ In the nineteenth century, the word was mainly used to identify Greeks, that is Orthodox Greeks, and by extension Europeans. Writing in the 188 os, engineer 'Ali Mubarak qualifies the new characteristics of modern construction in Egypt as rūmī, by which he seems to allude to imports from Europe and European master-builders, or alternatively Greek ones. ${ }^{37}$ However, in the context of French drawings captioned Kasr Roumi, the term has to be understood not from the point of view of an Arabic speaker, but from that of a French one. In other words, we are confronted again with the hybridised Arabic in use among European travellers who transferred what they picked up from colloquial language into their own tongue, where words could adopt slightly different meanings. In 1875 , a major French dictionary defines roumi as the name given by the Arabs to Christians, and by extension to Europeans. ${ }^{38}$ In short, "Kasr Roumi" can be translated either as "Greek Palace," "Christian/Orthodox Palace," or indeed "European

34 Paris, Collections des Beaux-arts de Paris, Fonds Jules Bourgoin, EBA 790o-0624 and o625.

35 Camel Kafadar, "A Rome of One's Own: Reflections on Cultural Geography and Identity in the Lands of Rum," Muqarnas: An Annual on the Visual Culture of the Islamic World XXIV (2007): 7-25.

36 Halil Inacik, "Rūmī," in The Encyclopaedia of Islam, eds. C.E. Bosworth et al. (Leiden: Brill, 1995), viII: 612. 'Ali Mubarak, Khitat, I: 214-16. Émile Littré, Dictionnaire de la langue française, supplément (Paris: Hachette, 1886), 302. 


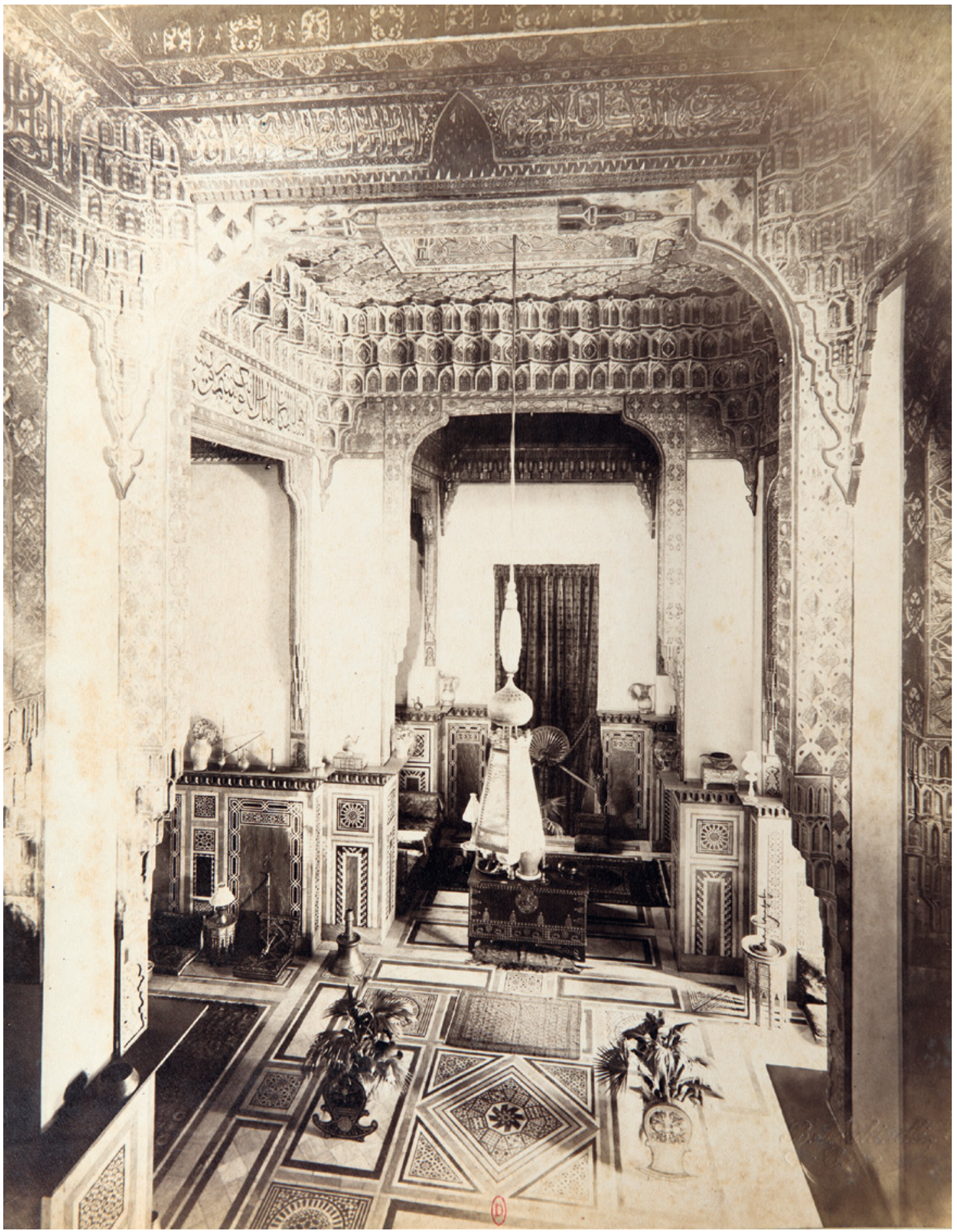

FIGURE 100 Beniamino Facchinelli, Salone (Casa Cte St Maurice). View of the grand parlour at the house of Saint-Maurice in Cairo photographed from the musicians' loggia. Mounted albumen print. $22 \times 28 \mathrm{~cm}$. Raccolta artistica di fotografie sull'architettura araba, ornati ecc. dal XII ${ }^{\circ}$ al XIII ${ }^{o}$ secolo fotografia italiana del Cav. B. Facchinelli, Cairo (Egitto), MDXXXLXXXVII [sic: XXX for CCC, soit 1887], f. 70

PARIS, BIBLIOTHÈQUE DE L'INHA, FOL PHOT 65 


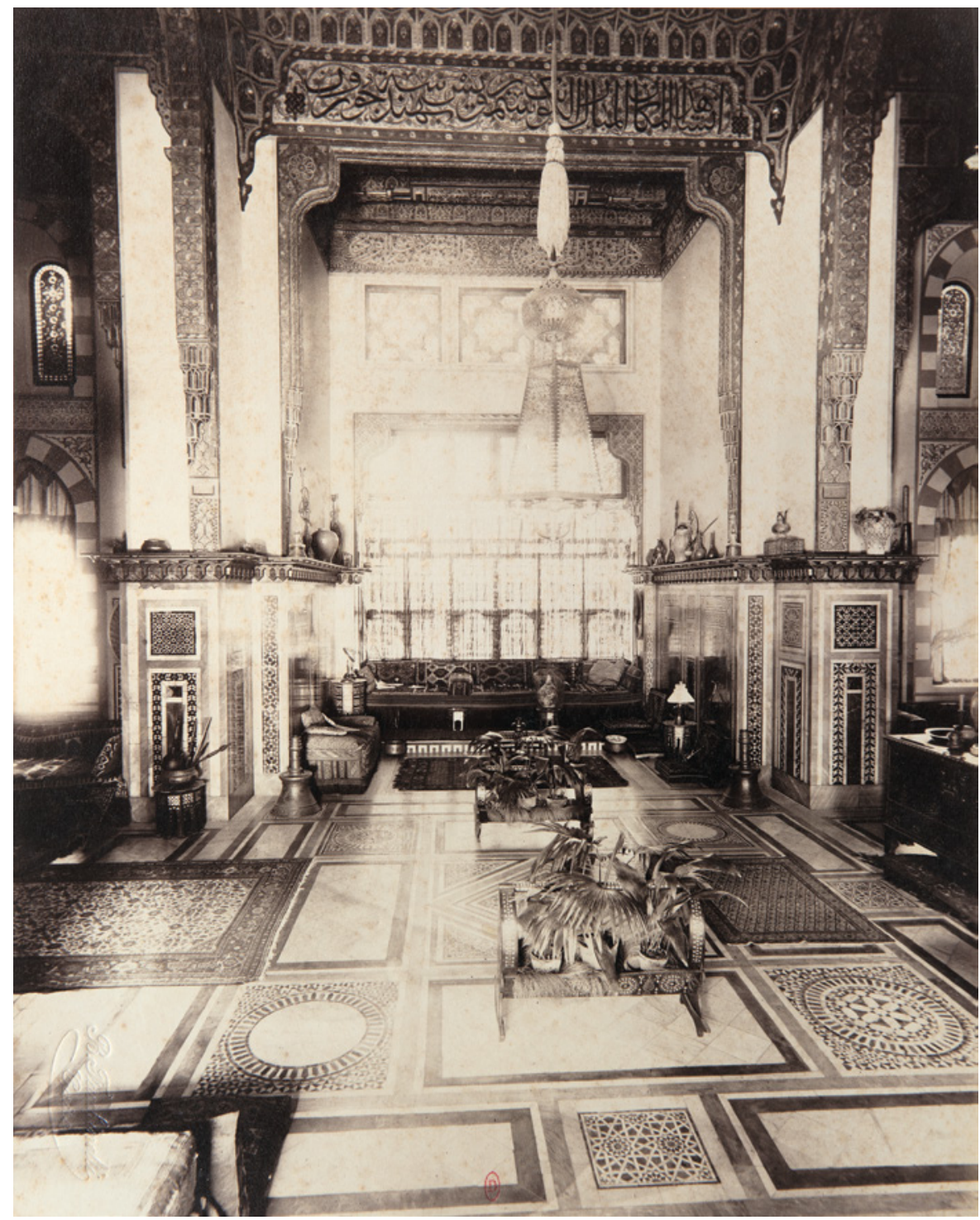

FIGURE 101 Beniamino Facchinelli, Interno Cte St Mce. The recess with mashrabiya lighting in the grand parlour of the Saint-Maurice house in Cairo. Mounted albumen print. $22 \times 27 \mathrm{~cm}$. Raccolta artistica di fotografie sull'architettura araba, ornati ecc. dal XII ${ }^{\circ}$ al XIII ${ }^{o}$ secolo fotografia italiana del Cav. B. Facchinelli, Cairo (Egitto), MDXXXLXXXVII [sic: XXX for CCC, soit 1887], f. 72 PARIS, BIBLIOTHÈQUE DE L'INHA, FOL PHOT 65

Palace." One place in Cairo could fit this description: the Palace of the Coptic Patriarchate where the British artist John Frederick Lewis lived for many years during the 1840 os. That palace (enlarged in 1781 , but disused by the Patriarch since the 1810s) was located in a street then known as Harat al-Rum [literally the street of the Christian(s)/Orthodox/ European(s)] in the heart of Historic Cairo; it adjoined one of its oldest Coptic churches. The house is no longer extant, and the street is now named Harat al-Zuwayla, but the ancient Church of the Virgin Mary still stands. ${ }^{39}$ If the hypothesis

39 Magdi Guirguis, "Nuṣūṣ jadīda hạla al-qalāyya al-bațiyarkiyya bi-Ḥārat al-Rūm," [New evidence on the Patriarchate Palace at Harat al-Rum], Annales 


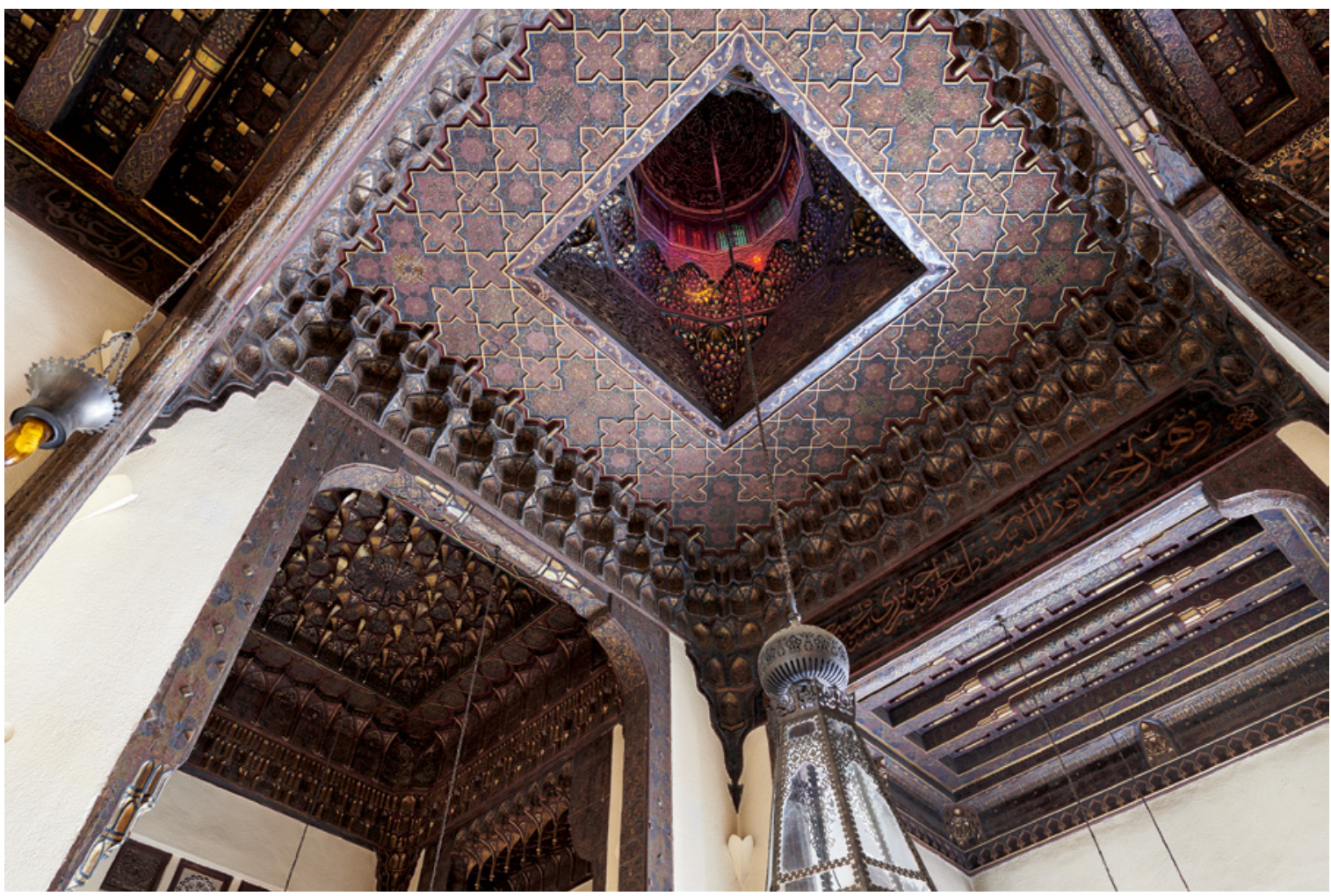

FIGURE 102 The central ceiling of the grand parlour of the Saint-Maurice house in its current state of reinstallation and colour scheme

PHOTOGRAPH BY MATJAZ KACICNIK, 2019

can be substantiated by written record, it means that parts of a Coptic Palace inhabited by a British artist started a new life in a French Arab-style house in the 1870s. Whatever the case, "Kasr Roumi" represents a further connection between the house of Saint-Maurice and Christianity.

The eight-pointed star module, interspersed with crosses, which provides the framework for the composition of the central ceiling in Saint-Maurice's reception hall, has Christian and Coptic connotations as well. (Fig. 105) Of course, the motif crossed cultures since Late Antiquity. In Norman Sicily, it famously decorated the coffered ceiling of the Capella Palatina (1140s); it can also be spotted on soffits at the Cathedral of

islamologiques 48/2, (2015): 191-215; Julien Auber de Lapierre, "Le Musée copte du Caire, une utopie architecturale," Annales islamologiques 5o (2016): 235-66.
Monreale (1170s). The motif then gave its shape to Persian lustre tiles from the Ilkhanid period (125os to 135 os). It features in many a drapery present in Italian painting. The patterned curtain behind the throne in the celebrated Rucellai Madonna by Duccio di Buoninsegna (1285) is one such example. The source for its motif of interlocking crosses with eight-pointed stars is believed to be a coeval Venetian silk. ${ }^{40}$ A seventeenth-century Qur'an from the Maghreb, reproduced by Prisse d'Avennes, bears the same motif. ${ }^{41}$ Going back in time, a number of Coptic textiles from the third to the sixth century already prominently exhibited

James H. Stubblebine, Duccio di Buoninsegna and his school (Princeton: Princeton University Press, 1979), I: 25 .

41 Émile Prisse d'Avennes, L'Art arabe, pl. 191. 


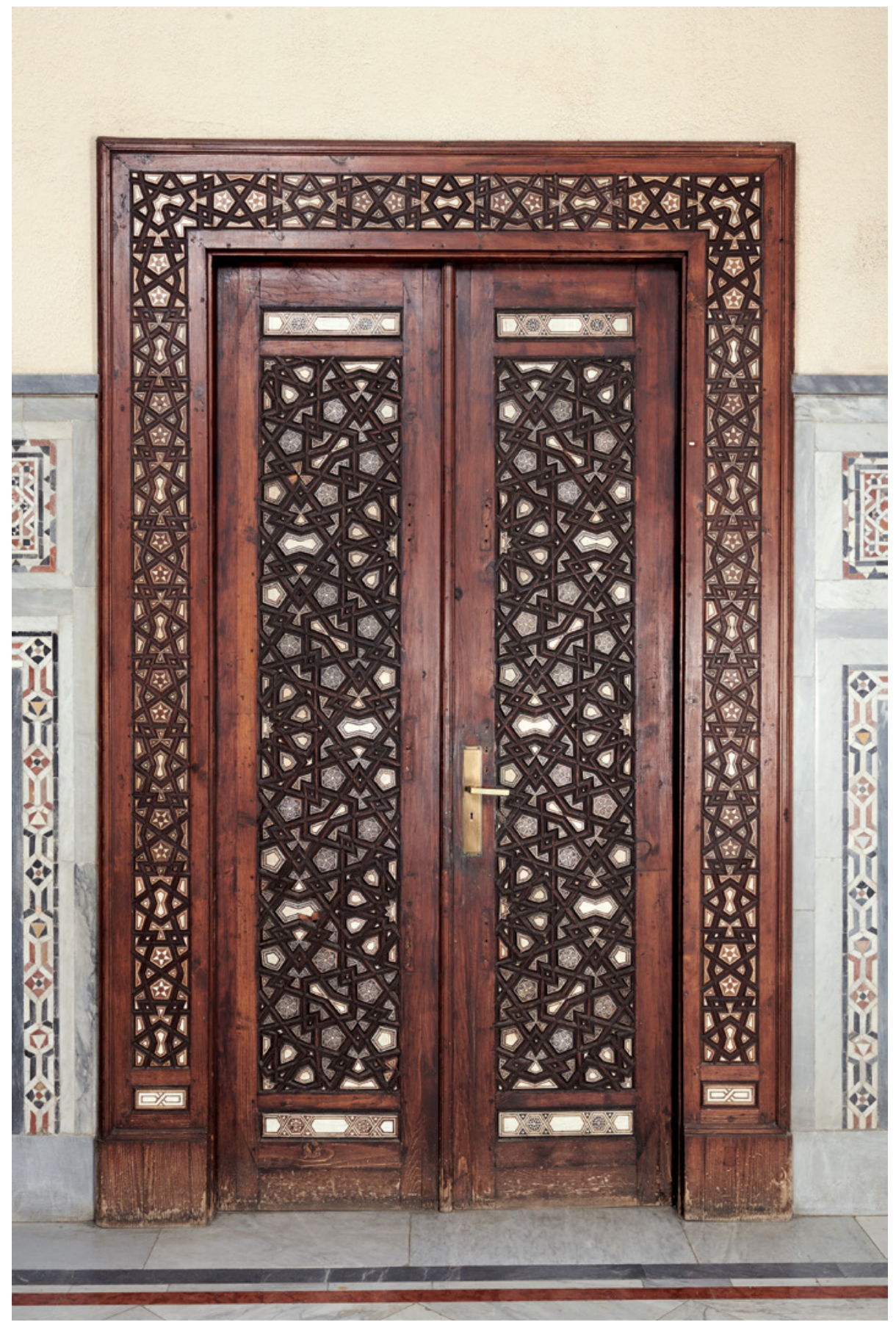

FIGURE 103

Fifteenth-century Mamluk door leaves from Saint-Maurice house in their current location

PHOTOGRAPH BY MATJAZ KACICNIK, 2019 


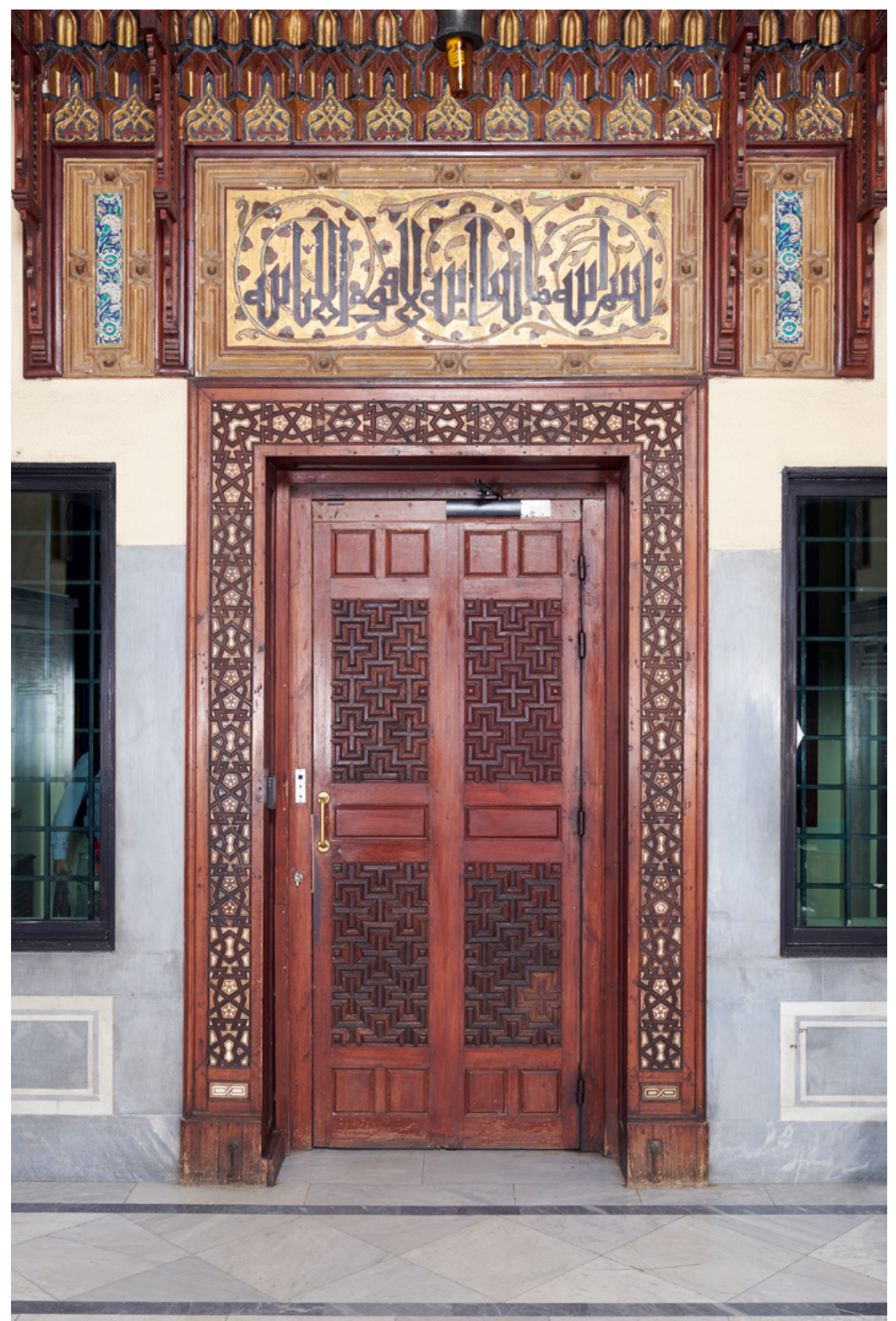

FIGURE 104

Door leaves with crosses from Saint-Maurice house in their current location PHOTOGRAPH BY MATJAZ KACICNIK, 2019 


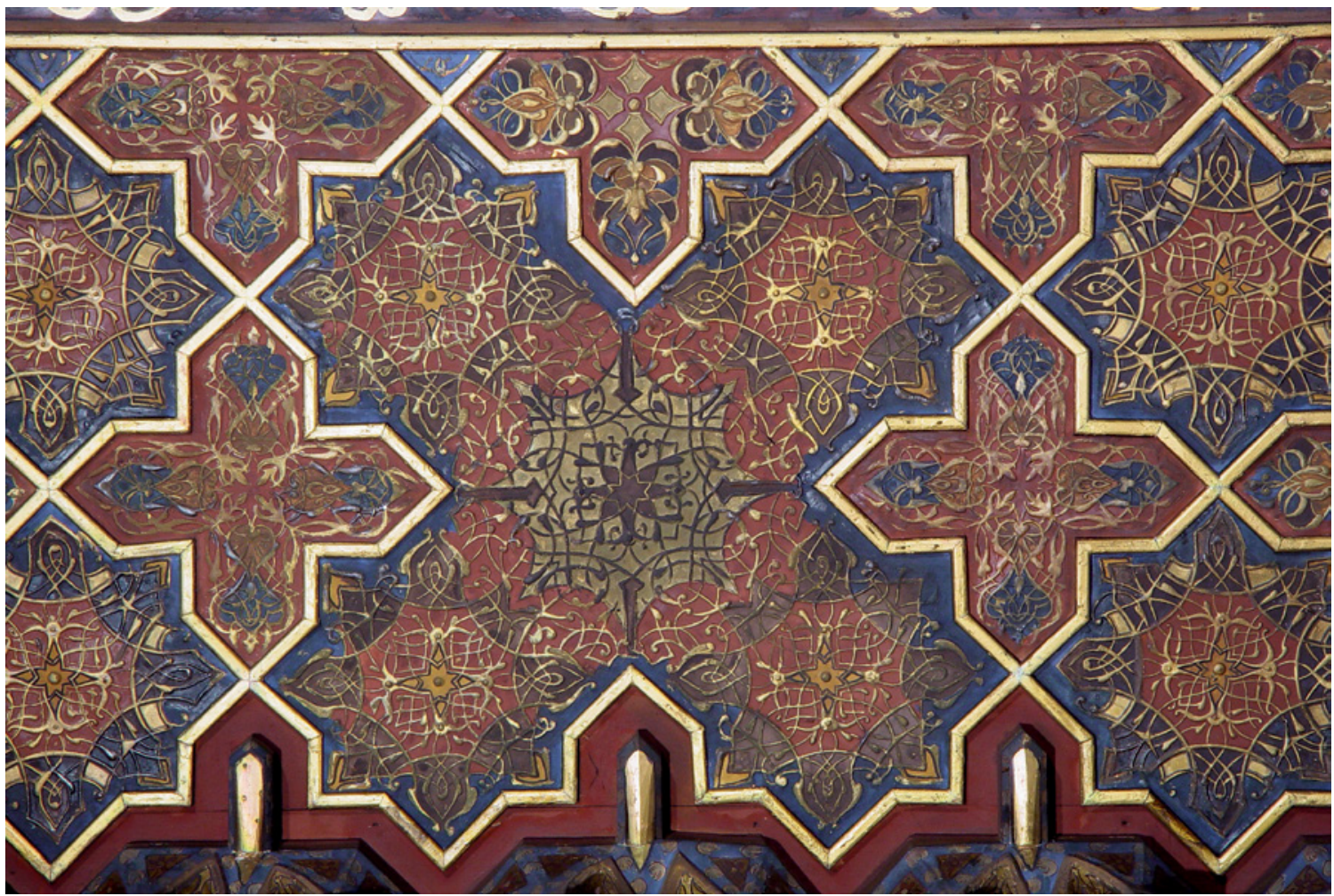

FIGURE 105 Detail of the central ceiling from the Saint- Maurice house in its current location PHOTOGRAPH BY DOMINIQUE ROUX, 2001

the eight-pointed star pattern. ${ }^{42}$ An example even closer to Saint-Maurice's decorative scheme, with the stars sharing a similarly intricate infilling, is to be found on the title page of an Arabic Gospel Book dated to the fourteenth century. (Fig. 106) The pattern faces a Byzantine style figurative illumination and the pair is viewed as illustrating how Coptic Egypt accommodated geometric arabesques, supposedly Islamic, by using them in conjunction with crosses. ${ }^{43}$ It has been even argued that the joint iconography symbolised the peaceful coexistence of Christian and Islamic civilisations in the

\footnotetext{
42 Several examples at the met.

43 Lucy-Ann Hunt, "An icon and a Gospel book: The Assimilation of Byzantine Art by Arab Christians in Mamluk Egypt and Syria," in Studies in Coptic Culture; Transmission and Interaction, ed. Mariam F. Ayad (Cairo: AUC Press, 2016), 93-116. The manuscript is MS Ahmet III 3519, currently kept at Topkapı Sarayı in Istanbul.
}

region. ${ }^{44}$ While the statement is anachronistic and questionable, the fact is that the eight-pointed star pattern with interlocking crosses enjoyed success in buildings designed by European architects for the Khedivial family during the 186os. The pattern appeared on ironwork at a fountain built in 1869 by architect Ciro Pantanelli for the Khedive's mother [sabill al-Walda], and it can also be spotted on the interior of the Khedive's pavilion at the Paris World's fair of 1867. (Fig. 2) Were all these connotations accessible to Saint-Maurice? What sustained the circulation of such a recognisable pattern from one building to another? No written sources allow a response to be offered. But it does consolidate the idea of the strong hold of Christian-connoted patterns, and Christianity more broadly, on

\footnotetext{
44 Jules Leroy, "Un évangéliaire arabe de la bibliothèque de Topqapi Sarayi à décor byzantin et islamique," Syria 44, no. 1-2 (1967): 119-3o (128).
} 


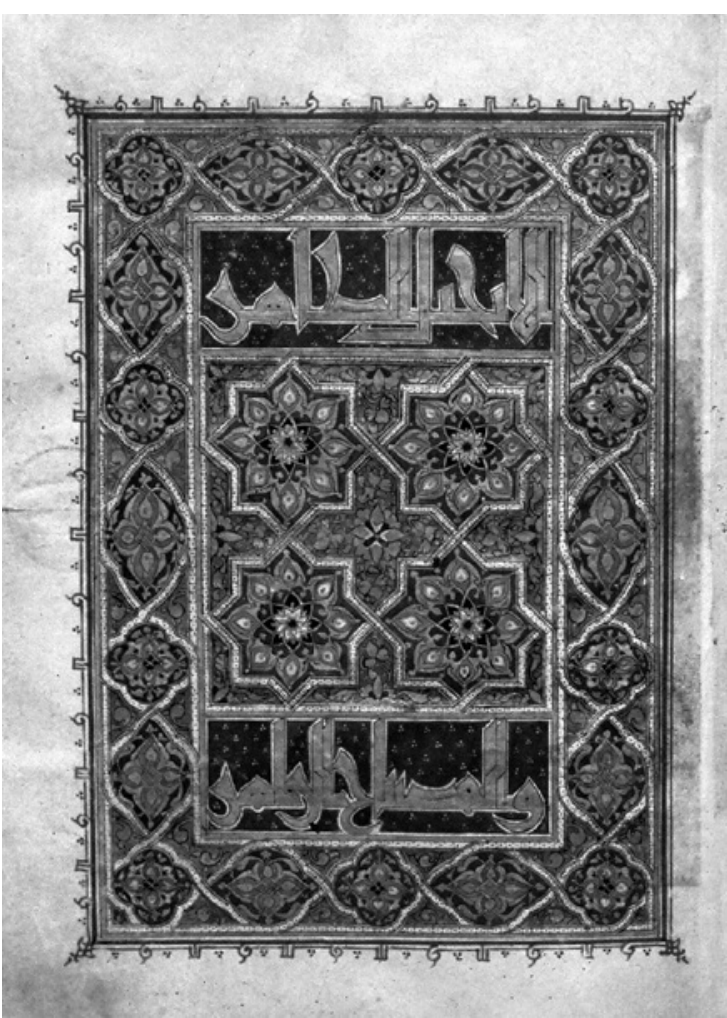

FIGURE 106 Title page of an Arabic Gospel in the collection of the Tokpaki Palace ISTANBUL TOPKAPI SARAYI MÜZESI LIBRARY, MS AHMET III 3519, IV

European and American enthusiasm for Cairene and Damascene art and architecture.

What can be further argued is that Christian houses had in general been more accessible to Westerners than Muslim ones. Most images of reception rooms produced by European artists during their visits to Egypt depict inhabited Christian homes. Abandoned or disused Muslim ones represented the other prime resource available to artists. An early illustration of the former type is provided in a wonderful watercolour by the Swiss artist Charles Gleyre (1806-74), dated January 1835. (Fig. 107) The Madonna with Child at the far end of the room leaves little doubt as to the Christian identity of the house's inhabitants. As just mentioned above, John Frederick Lewis spent many years in Cairo renting the Palace of the Coptic Patriarchate. During the 183 os Émile Prisse
d'Avennes, and later in the 1870 os the photographer Gustave Le Gray, both also rented their historic houses from Christian owners. ${ }^{45}$ Another often sketched room during the nineteenth century was the old mandara of the Mufti's house - the very one that the religious official refused to sell to the South Kensington Museum in 1890-91 despite not using it, as seen in Chapter 3. It had long been opened to artists, judging from the number of drawings, paintings, photographs and engravings depicting the place since 1848. (Fig. 108) Al-Musafirkhana, belonging to the Khedivial family, was also an empty house that was occasionally let to travellers, as its very name indicated. In retrospect, the openness to artists of Manzil al-Sadat, discussed in Chapter 3, appears in fact rather extraordinary.

A black and white photograph of the main ceiling of Saint-Maurice's reception room, taken in the 189os, shows that at the time, each eight-pointed star bore at its centre a cross with branches of equal length painted in a light colour or with gild. (Fig. 109) All indications are, hence, that the decorative scheme was perceptibly Christian at first sight, even though the crosses are no longer distinguishable. They were probably painted over, after the room was dismantled and migrated in 1937, in a way that rendered them indiscernible. In addition, the name of Allah was added two times on the wall of one of the recesses. (Fig. 110) The French authorities, or their architect, probably judged it more appropriate to add the name of the Muslim God at a time when their politics of influence were shifting towards more interaction with Islam, following the Protectorate in Morocco in particular. It is no accident that the new Legation in Giza was constructed in 1937 to resemble modern Moroccan architecture; the colonial style was now seen by the French ambassador as the quintessential Arab

45 Mercedes Volait, "Figuration et fortune artistique des intérieurs du Caire au XIX ${ }^{\mathrm{e}}$ siècle," in The Myth of the Orient: Architecture and Ornament in the Age of Orientalism, eds. Francine Giese and Ariane Varela Braga (Bern: Peter Lang, 2016), 17-33. 


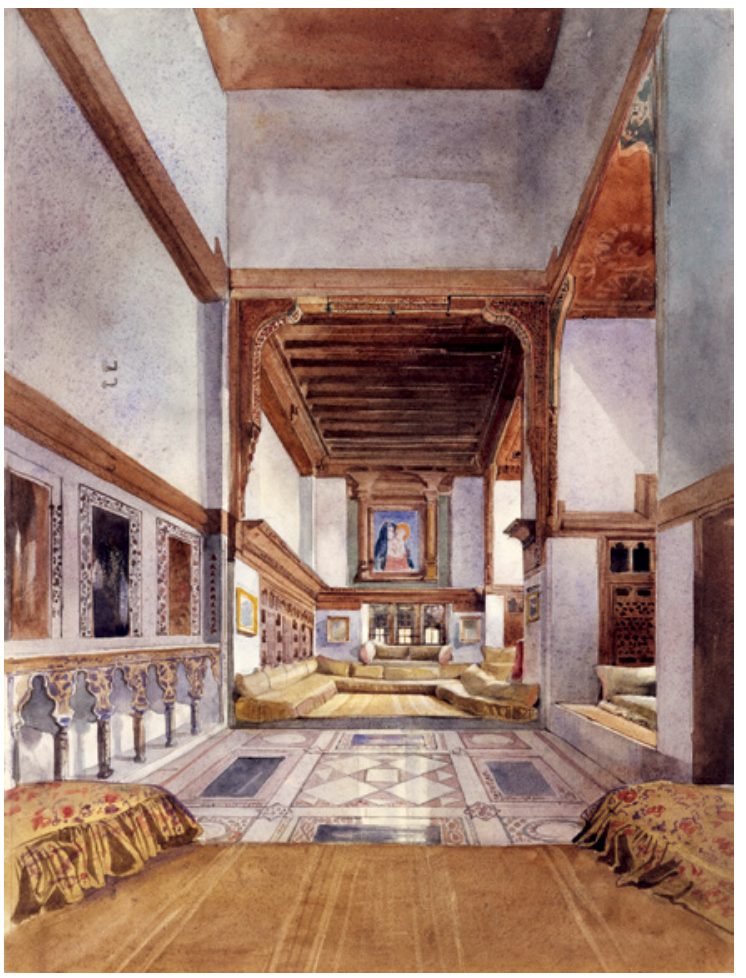

FIGURE 107 Charles Gleyre, Intérieur de

maison chrétienne en Égypte,

Janvier 1835. Watercolour and pencil on

paper. $33.1 \times 25.1 \mathrm{~cm}$

BOSTON, MA, THE LOWELL INSTITUTE, ON LOAN TO MUSEUM OF FINE ARTS, BOSTON, 137.49

modern style in architecture, in contrast with the type of Islamic Revival that had developed in Egypt and that he judged over ornate and of terrible taste. In his very words:

[La nouvelle chancellerie] est conçue dans ce style marocain sobre et dépouillé où se retrouvent toutes les traditions de l'art arabe, de Damas à Grenade, et dont l'adaptation aux besoins administratifs n'est pas la moindre gloire du Maréchal Lyautey. ${ }^{46}$

46 "[Our new agency] is conceived in the sober and bare Moroccan style where all traditions of Arab art, from Damascus to Granada, melt and which adaptation to public buildings is the not inconsiderable achievement
The master bedroom of Saint-Maurice house's displayed more reused woodwork, together with what records described as an "Arab bed" in rosewood, inlaid with glass and ivory, from the Hijaz. ${ }^{47}$ (Fig. 111) Rugs, tabouret-tables and a large trunk completed the furniture. The latter belonged to a group of objects known as "Arab chests." ${ }^{48}$ These portable items were mainly manufactured in India, and incorporated stylistic influences traceable to the Dutch and the Portuguese. Arab chests were highly prized by diplomats, colonial administrators and other expatriates posted in the region in the eighteenth and nineteenth century. Another specimen is significantly mentioned in the inventory of Saint-Maurice's belongings as a coffer "retour des Indes" [Returning from India]. ${ }^{49}$ It is not known if Saint-Maurice procured the chest in Cairo or elsewhere.

In addition to salvage, plaster casts of historic ornaments contributed to surface ornamentation. The walls of the large terrace adjoining the reception hall were covered with a series of replicas of Mamluk stonework that can be traced to specific details in the mosques of al-Sultan Hasan (mid-fourteenth century) and Qaytbay at Qal'at al-Kabsh (late fifteenth century). A large panel was obtained by the duplication of a pattern based on a stuccoed niche in the Mosque of al-Mu'ayyad Shaykh (fifteenth century). (Fig. 112) Saint-Maurice's house represents an early instance

of Marshall Lyautey." [My translation]. Nantes, Archives rapatriées des postes, Le Caire Ambassade, 353PO/2/406, Letter of ambassador Pierre de Witasse to the Ministry of Foreign affairs, 19 July 1937 where he also mentions "la complication 'pâtissière' de l'architecture officielle d'Égypte." In the same file a French article dated 12 November 1937 mentions again the contrast of modern Arab architecture in Morocco with "l'architecture locale si pesamment ornée" [the local architecture so heavily ornate] of Egypt. Nantes, Archives rapatriées des postes, Le Caire Ambassade, 353PO/2/407, Inventaire de la maison G. de Saint-Maurice au Caire, June 1884.

48 Sheila Unwin, The Arab Chest (London: Arabian Publishing, 2006), 105.

49 Volait, Maisons de France, 89. 


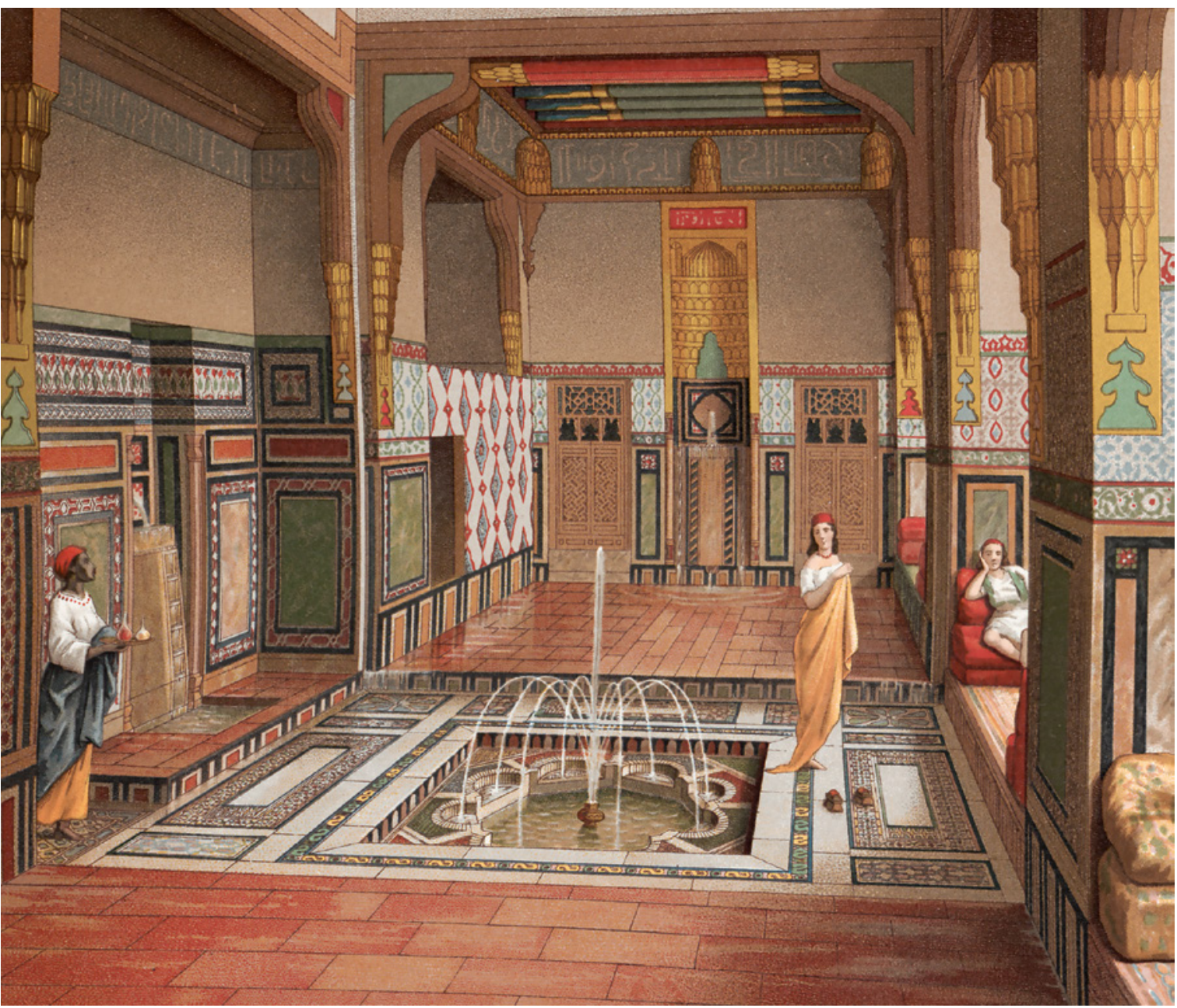

FIGURE 108 Stéphane Baron, Untitled. The painted partition closing one of the recesses on the far left end exemplifies a common refurbishing device, already encountered at Manzil al-Sadat. Chromolithograph based on a photograph AUGUSTE RACINET, LE COSTUME HISTORIQUE ..., 1876-88, III: PL. 166

where the mechanical reproduction of historic ornament featured so boldly. The movement had been launched at the Exposition universelle of 1867 in Paris by an International convention advocating plaster copies as a mass medium for the dissemination of historic architecture; from there it developed fast until it was discovered that casting damaged the originals. ${ }^{50}$

$50 \quad$ "Convention for promoting universally reproductions of works of art for the benefit of museums of all countries," Mari Lending, Plaster Monuments: Architecture
One decorative fixture of the terrace was a tile panel very similar to the one brought back from Syria by Frederic Church. (Fig. 113) While made of twenty-four tiles instead of thirty-two, the panel possessed a colour scheme and motifs identical to the one located at Olana House. This is one of several indications relating, unpredictably, Saint-Maurice's house to Damascus.

Another is a contract signed on 16 April 1875 with a carpenter from Damascus, named Salah Ibn 'Ali

and the Power of Reproduction (Princeton: Princeton University Press, 2017). 


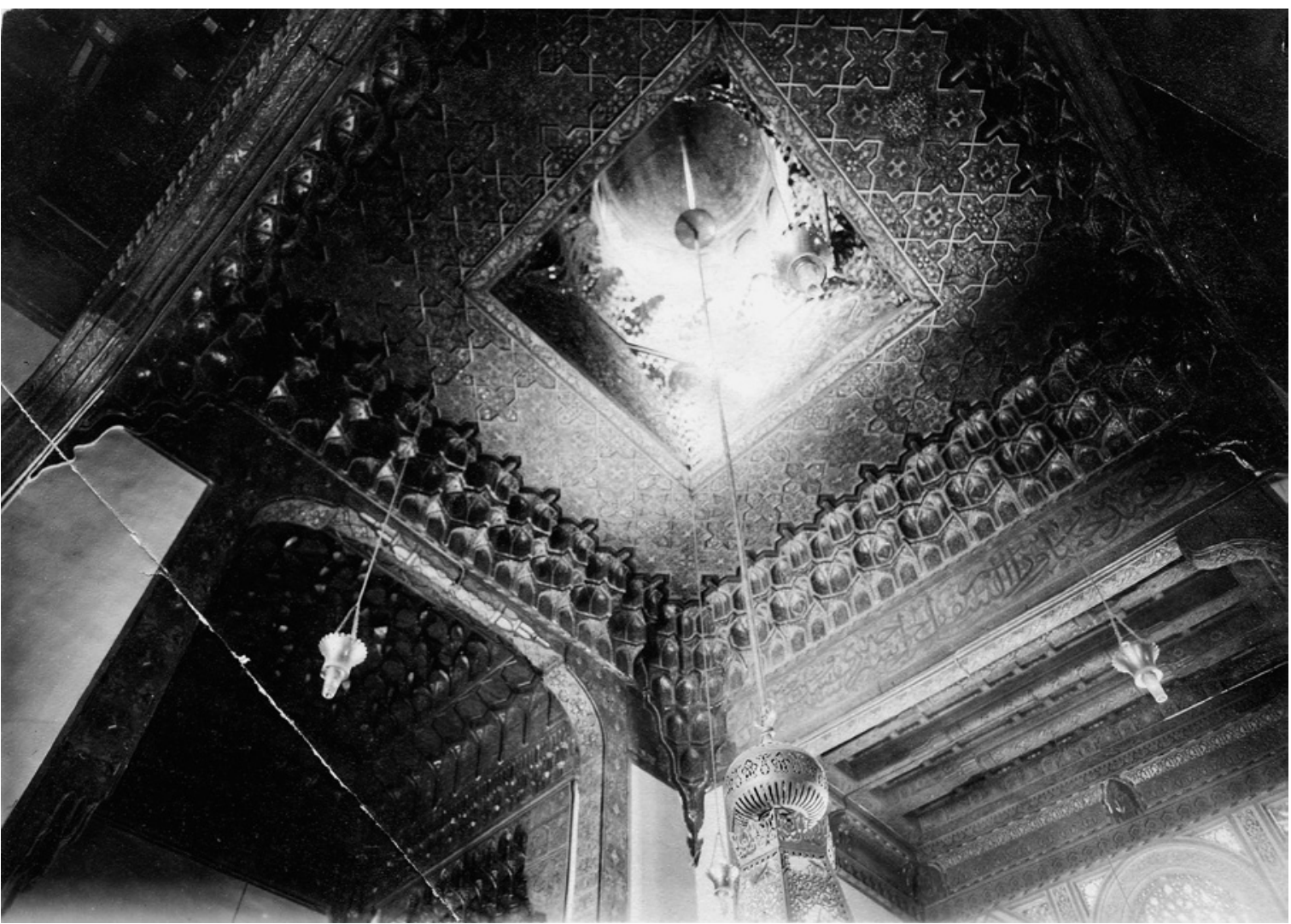

FIGURE 109 Anonymous, The central ceiling of the grand parlour at the Saint-Maurice house in Cairo. Undated. Albumen print. No dimensions provided

CAIRO, MARKAZ AL-DIRĀSĀT AL-ATARIYYA [THE CENTER FOR HERITAGE STUDIES]

Abu Lahaf, al-najjāral-shāmīmin tumnal-Qanawāt [the Syrian carpenter from al-Qanawāt, a suburb southwest of Damascus]. The contract stipulated that the artisan was to work for Saint-Maurice in Cairo for a full year, on an exclusive basis. The hiring document was endorsed by French architect Jules Bourgoin, acting in Damascus as a representative of Saint-Maurice. The text does not detail the work assigned to the carpenter; it only stated that he had to accomplish any task commissioned by Saint-Maurice. ${ }^{51}$ This might have included the production of tabouret tables; a photograph depicts a substantial set of them in Saint-Maurice's front yard. (Fig. 116) Salah might have worked

51 Paris, Bibliothèque de l'ınha, Archives o67 (Jules Bourgoin Papers). on the composite doors, made of historic panels inserted into modern frames and exhibited by Saint-Maurice in Paris in 1878 , or on the cupboard made for the same show. ${ }^{52}$ He might have also been entrusted with making adjustments to items of salvage from Damascus. At the exact time of his hiring, Bourgoin was negotiating, as already mentioned, the potential purchase of three old ceilings that were in "good condition" and could be obtained at a reasonable price if their replacement with "painted canvases in the Frankish manner" was provided for. ${ }^{53}$ It is not clear if these pieces of salvage were ultimately incorporated at

$5^{2}$ London, v\&A museum, 889-1884.

53 "Plafond en toile peinte ou peinturlurée à la franque;" Pierrefitte-sur-Seine (France), Archives nationales, 


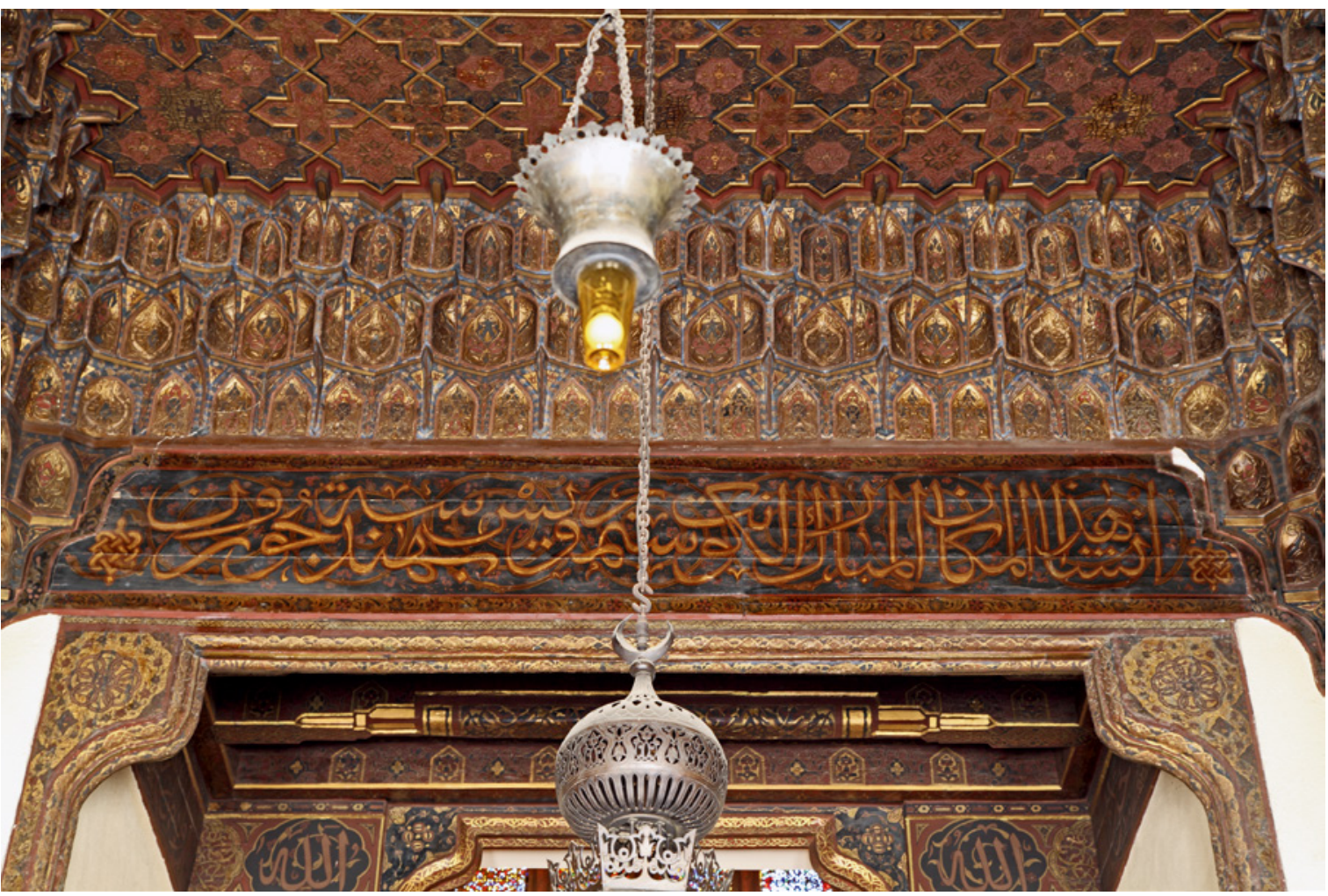

FIGURE 110 The first part of the Saint-Maurice house's foundational inscription. The name of God in Arabic can be identified within the left and right cartouches in the background

PHOTOGRAPH BY BLAS GIMENO RIBELLES, 2012

Saint-Maurice's, but the drawing of one of them (fig. 114) is captioned in several sources either as a ceiling coming from Damascus or as an element at Saint-Maurice's or indeed as a ceiling in Cairo. ${ }^{54}$ Finally, the house included among its metal objects an eight-lobed doorknocker that is typical of a type of production attributed to late Ottoman Damascus. ${ }^{55}$ (Fig. 115)

$\mathrm{F}^{17} 2941$ (36), item no. 26, Jules Bourgoin's mission to Damascus 1874-75.

54 Maryse Bideault and Bassam Dayoub, "Une saison damascène, 1874-1875," in De l'Orient à la mathématique de l'ornement. Jules Bourgoin (1838-1908), eds. Maryse Bideault et al. (Paris: Publications de l'inha, 2015) [https://books.openedition.org/inha/7021].

55 An almost identical specimen was auctioned at Sotheby's London on 2 May 1977; Stefan Heidemann, "Late Ottoman Doorknockers from Syria," in Facts and Artefacts, Art in the Islamic World, eds. Annette
In sum, Olana House in upstate New York and Count Saint-Maurice's residence in Cairo, while thousands of miles apart, shared identical features: references to Damascene visual and material culture, Syrian salvage, inscriptions as a decorative scheme and with connections to Eastern Christianity in the guise of Biblical verses reproduced in Arabic. Their aesthetic interiors were the product of a very specific and ephemeral moment: the encounter at the end of the 186os with the commodification of late Ottoman architecture and design, particularly Christian, by Westerners interested in the Near Eastern roots of their religious persuasion. They illustrate forms of intermediacy: the transfer from the medium of manuscript and printed illustrations onto that

Hagedorn and Avinoam Shalem (Leiden: Brill, 2007), $153-84$. 


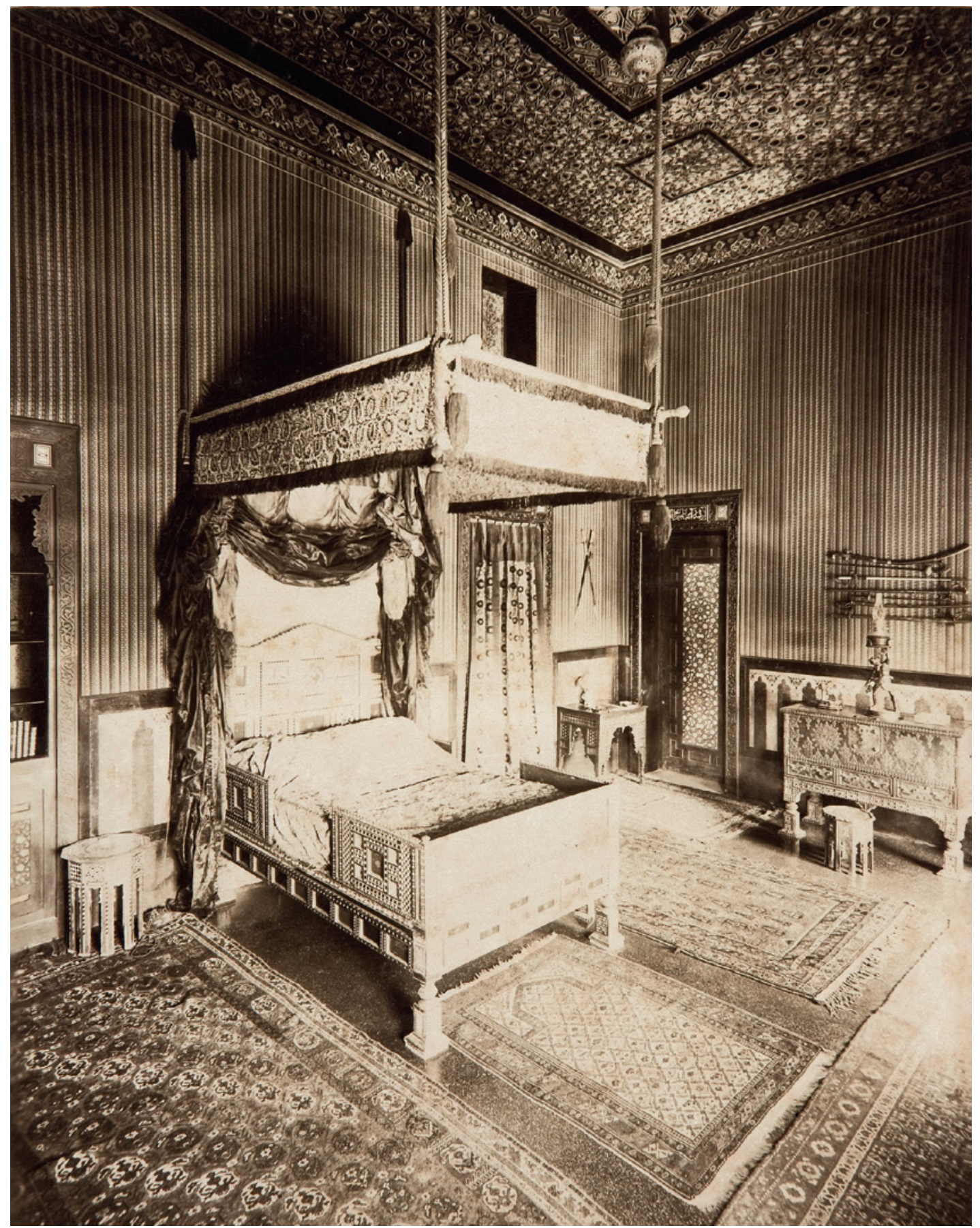

FIGURE 111

Beniamino Facchinelli, Stanza da letto (Cte St Mce). Saint-Maurice's bedroom with a bed believed to be from the Hijaz. Mounted albumen print. $22 \times 28 \mathrm{~cm}$. Raccolta artistica di fotografie sull'architettura araba, ornati ecc. dal XII ${ }^{\circ}$ al XIII ${ }^{\circ}$ secolo fotografia italiana del Cav. B. Facchinelli, Cairo (Egitto),

MDXXXLXXXVII [sic: XXX for CCC, 1887], f. 83

PARIS, BIBLIOTHÈQUE DE L'INHA, FOL PHOT 065 


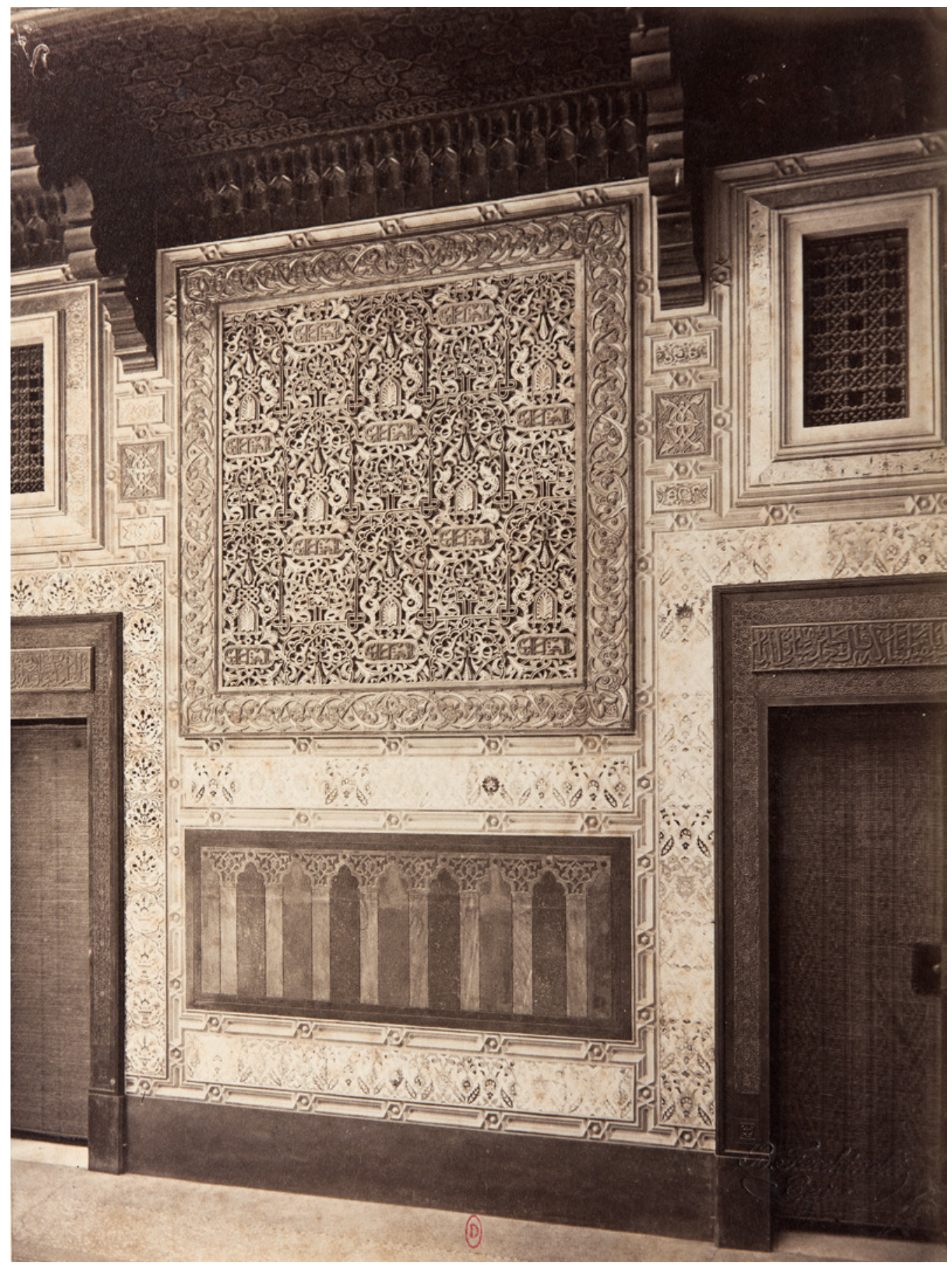

FIGURE 112

Beniamino Facchinelli, Dettagli e Ornati della Terrazza (Cte St Mce). The panel was made after a pattern inspired by stucco work in the Mosque of al-Mu'ayyad Shaykh. Mounted albumen print. $20 \times 26 \mathrm{~cm}$. Raccolta artistica di fotografie sull'architettura araba, ornati ecc. dal XII ${ }^{\circ}$ al XIII ${ }^{o}$ secolo fotografia italiana del Cav. B. Facchinelli, Cairo (Egitto), MDXXXLXXXviI [sic: XXx for CCC, 1887], f. 78

PARIS, BIBLIOTHÈQUE DE L'INHA, FOL PHOT 065 


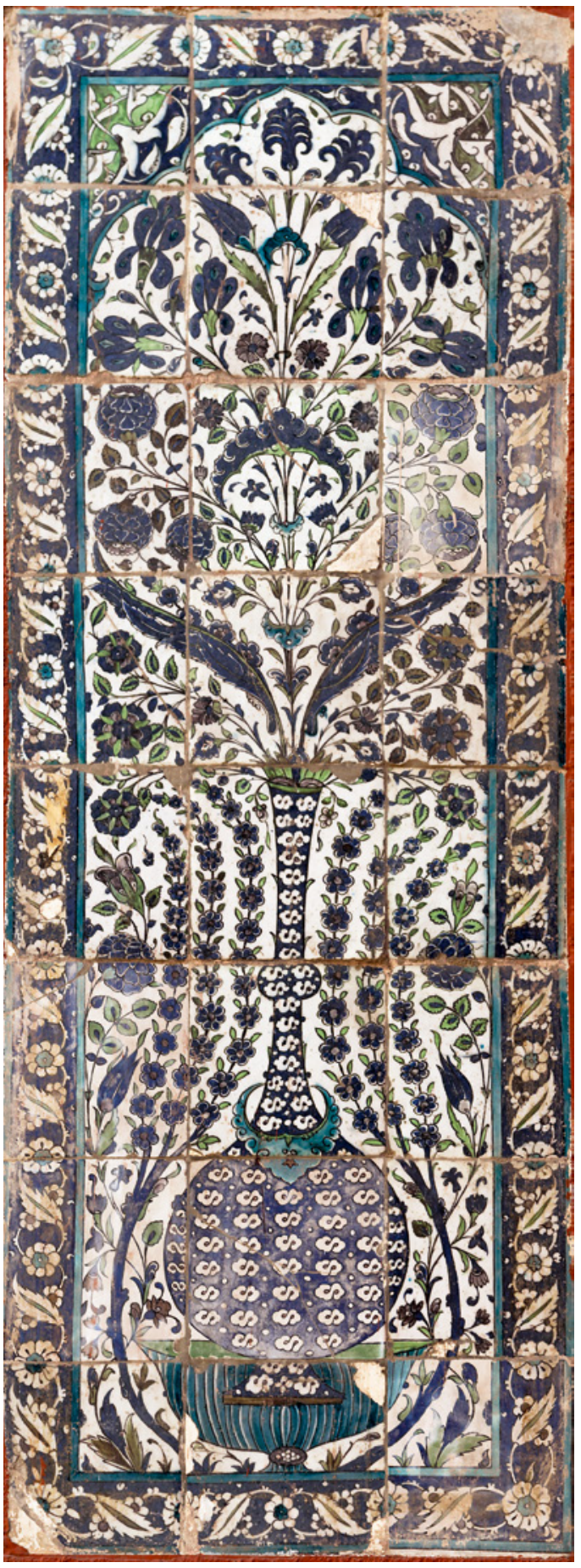

FIGURE 113
Tile-panel of Damascene provenance from the house of Saint-Maurice in Cairo in its current location PHOTOGRAPH BY PASCAL MORA, 2019 of painted decoration. The formal contrasts of Church's American "Eden" and Saint-Maurice's French "Alhambra," to refer to coeval expressions used to depict them, cannot be explained only by their distinct authorship. They are affected too by their distance from the ruins and the measure of architectural reuse: from a few fragments at Olana to full ceilings, dados and floors at Saint-Maurice's. That the French aristocrat turned to Damascus for craftsmanship and craftwork, together possibly with salvage, is indeed worthy of note. It means that reuse and recreation were not the mere result of pragmatism or availability, due to the sheer amount of rubble then existing in Cairo. They were the outcome of intention. It was a conscious and deliberate scheme that spared no energy to achieve its goal. The fact that Saint-Maurice's accomplishment was copied elsewhere, such as in "Arab rooms" created by a German aristocrat in Stuttgart in ${ }^{1895}-98,{ }^{56}$ reinforces the point: collectors could expend considerable effort to realise their historicist visions, whatever it cost in time, effort or money. The German reach of Saint-Maurice's interiors suggests in turn that the aesthetic mood could cross national boundaries, while firmly rooted in a specific French formula of historicism, as we shall see now.

\subsection{An "Arab Cluny"}

A third case study provides further leads in helping to situate Islamic Revival interiors within broader cultural dynamics. While of unparalleled scale, Saint-Maurice's mansion was not an isolated enterprise in Cairo. It relates to a group of houses all created during the same decade by French expatriates attached to the Khedivial court, all of whom were Islamic art collectors. The first built belonged to Alphonse Delort de Gléon, the man behind the creation of the Islamic section at the Musée du Louvre thanks to the donation of his

56 Francine Giese, "International fashion and personal taste: Neo-Islamic style rooms and orientalizing scenographies in private museums", in Giese et al., À l'orientale, 92-108. 


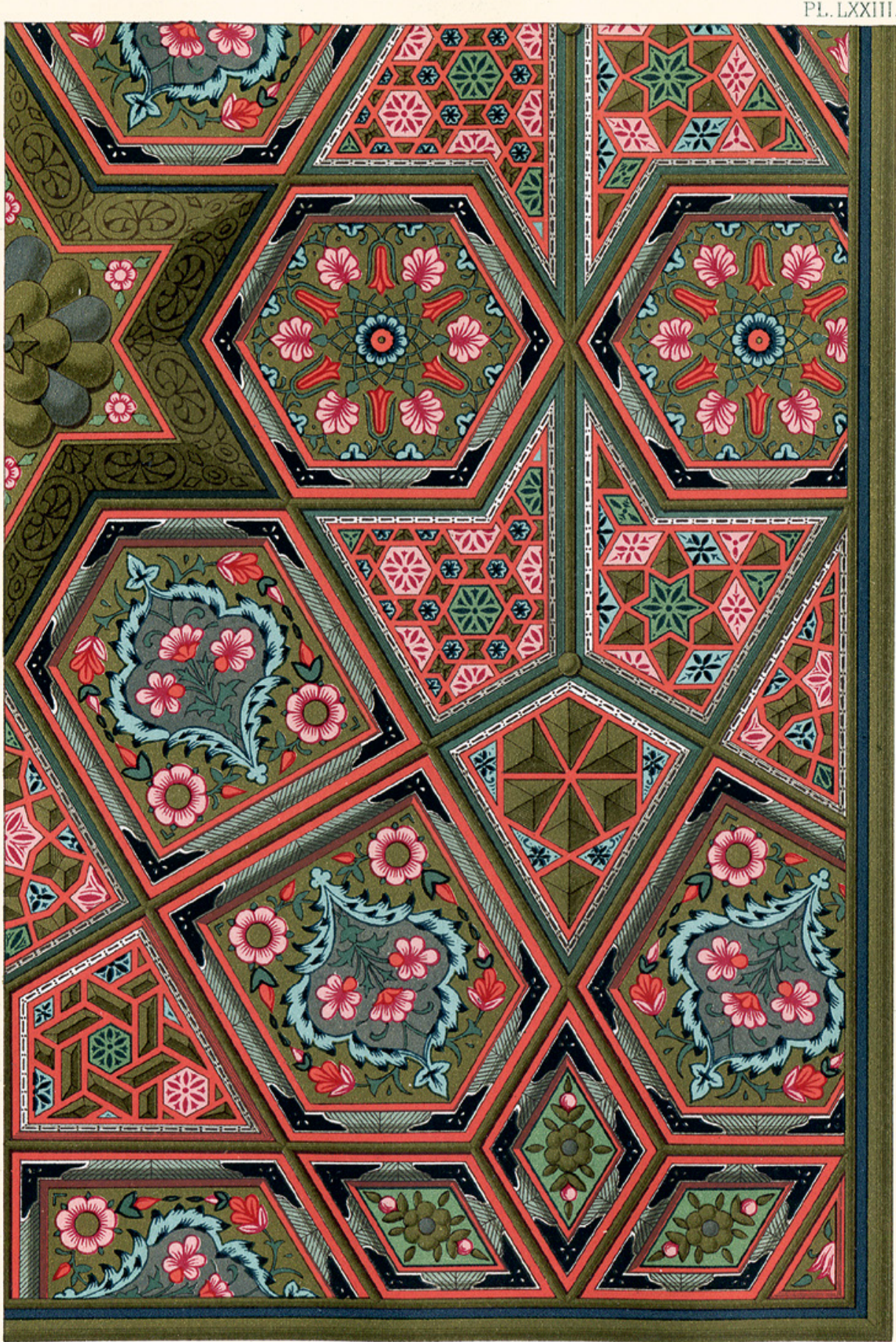

Bourgoin del.

Schnidt lith.

FIGURE 114 Jules Bourgoin, Plafond d'une maison de Damas du XVIII e siècle. The eighteenth-century ceiling from Damascus was offered to Jules Bourgoin as salvage in 1875. Chromolithograph ERNEST BOSC, DICTIONNAIRE RAISONNÉ DE L'ARCHITECTURE ET DES SCIENCES ET DES ARTS QUI $S$ 'Y RATTACHENT 1879, III: PL. LXXIII 


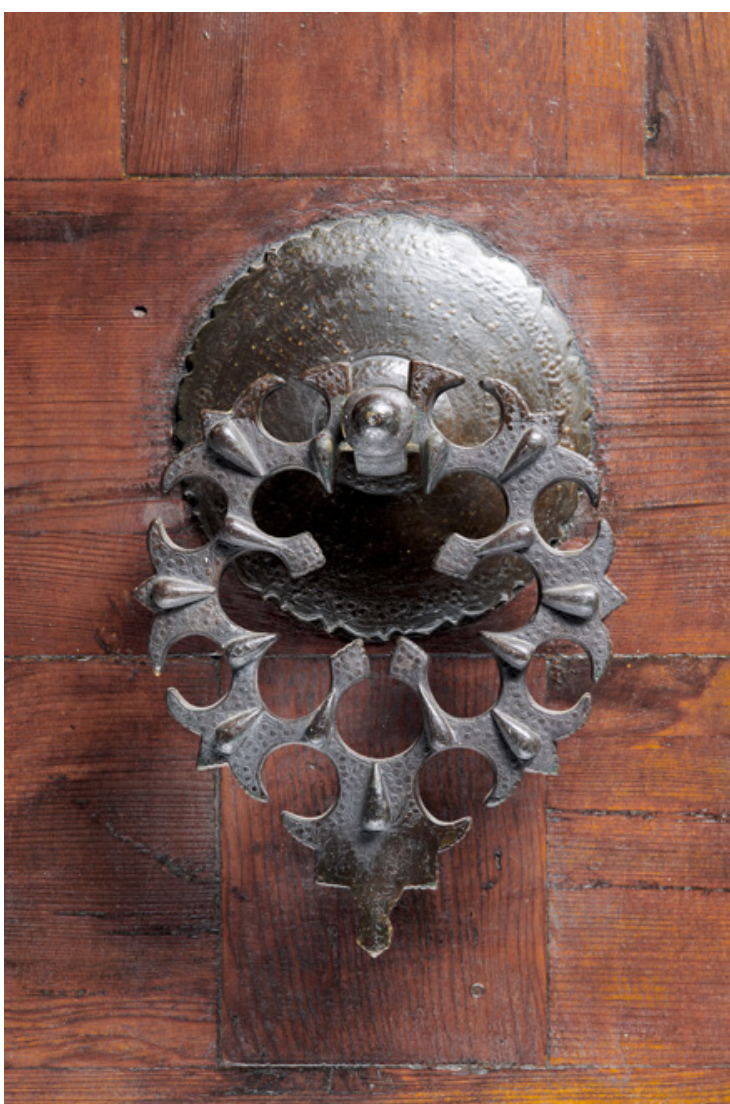

FIGURE 115 Doorknocker from Saint-Maurice's house, attributed to late Ottoman Syria, in its current location

PHOTOGRAPH BY MATJAZ KACICNIK, 2019 in 1855 , when he was barely seventeen years old, after asking his brother for books on Antiquity:

parce que j'ai soif d'instruction et que l'étude de l'Antiquité est très instructive et très amusante. Avec une pièce, je reconstruis un règne, je vois l'empereur. J'apprends quelles sont ses habitudes, ce qu'il a fait, etc. Avec le secours de l'imagination, je reconstruis un passé depuis longtemps évanoui et les moments que je passe en cette occupation me procurent un plaisir infini. ${ }^{58}$

Living in Cairo from 1871 to 1886 , after having supervised the construction of the Paris Opera under the guidance of his mentor Charles Garnier, Baudry managed to assemble an exceptional collection of 279 Iznik tiles, besides pieces of Fatimid, Mamluk and Ottoman metalwork and woodwork, including a dated Coptic arch made out of reused Ancient Egyptian carved wood, reputedly found at a church in Asyut (Upper Egypt). ${ }^{59}$ (Fig. 117 and 118) The tiles ${ }^{60}$ and part of the woodwork entered the Louvre in 1898, while further woodwork joined the Metropolitan Museum of Art in 1907 (Fig. 119); the remaining pieces were dispersed over the years, and ultimately auctioned off in Paris in 1999 and $2000 .^{61}$

58 Private collection, France, Letter of Ambroise Baudry to his brother Paul, 14 April 1855: "because I have a thirst for education and because the study of Antiquity is very instructive and entertaining. With a coin, I reconstruct a reign, I see the emperor. I learn what his habits were, what he did, etc. With the recourse of imagination, I reconstruct a past long since vanished and the moments I spend in this occupation bring me infinite pleasure." [My translation].

59 Currently at the Louvre, E 32578 , on show in the Baouit Rooms.

6o Catalogued as OA $4047 / 1$ to 258 , these tiles are searchable on the online portal of the Musée du Louvre's collections, released in 2021.

61 Crosnier Leconte and Volait, L'Égypte d'un architecte, 134-47; Arts d'Orient, Drouot Montaigne, Paris, 7 June 1999, lots 76 to 147 and Arts d'Orient, Drouot-Richelieu, Paris, 11 December 20oo, lots 98 to $120 ; 172$ to 195 .

57 Crosnier Leconte and Volait, L'Égypte d'un architecte. 


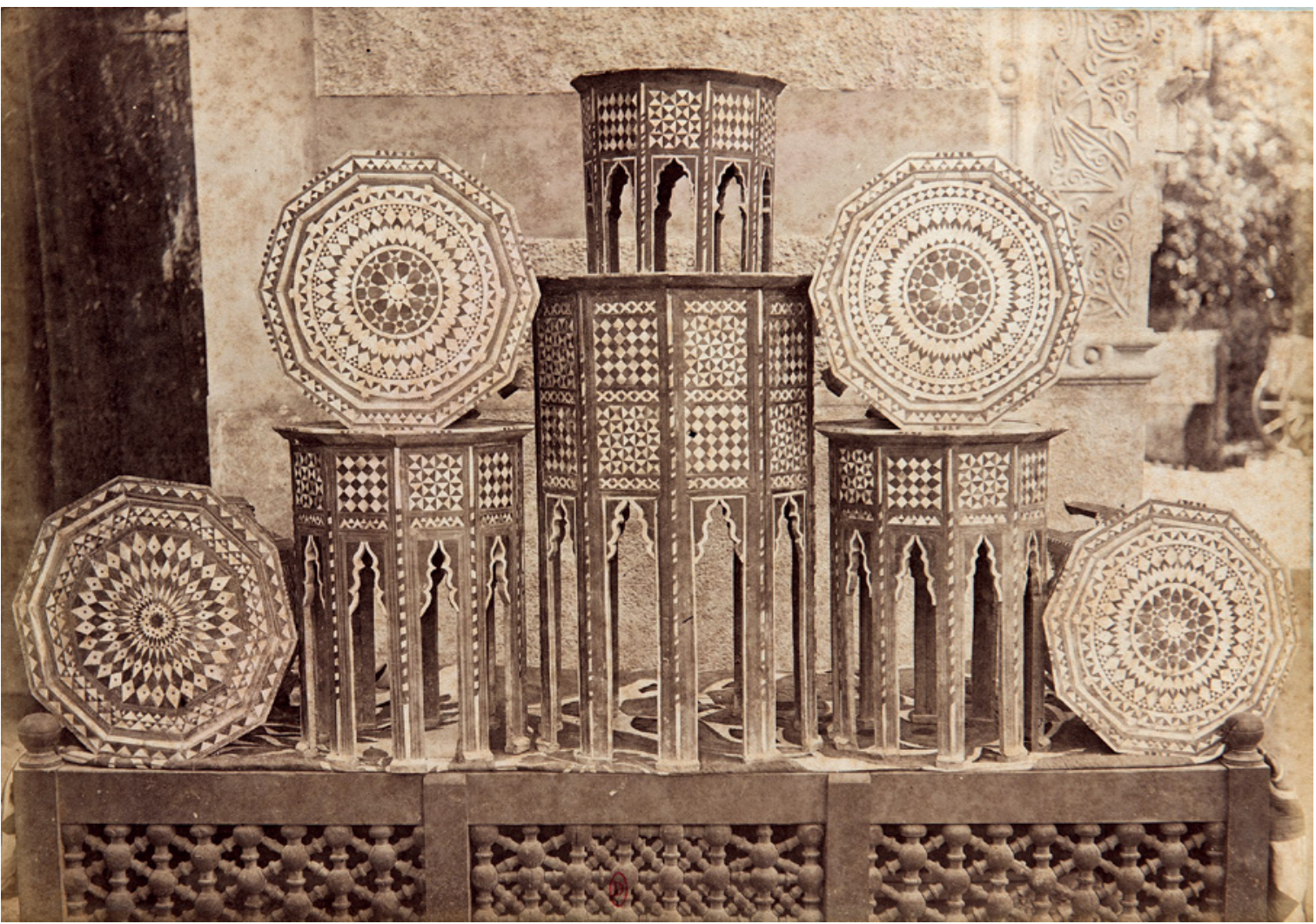

FIGURE 116 Beniamino Facchinelli, Ornati e tabourets (Cairo). Tabouret tables displayed in the front yard of Saint-Maurice's house. Mounted albumen print. $25 \times 18 \mathrm{~cm}$. Raccolta artistica di fotografie sull'architettura araba, ornati ecc. dal XII ${ }^{\circ}$ al XIII ${ }^{\circ}$ secolo fotografia italiana del Cav. B. Facchinelli, Cairo (Egitto), MDXXXLXXXVII [sic: XXX for CCC, 1887], f. 166 PARIS, BIBLIOTHÈQUE DE L'INHA, FOL PHOT 065

The Delort de Gleon villa, meanwhile, is still extant though in very poor condition, ${ }^{62}$ and represents Baudry's first attempt to come to terms with the Islamic Revival style while remaining as faithful as possible to historic sources. There was some plaster-casting involved, but above all new historicist design. Baudry created wooden panels for the doors and marble mosaics for the dados, based most probably on specific originals. ${ }^{63}$ (Fig. 120) The architect was then involved in the designing of Saint-Maurice's house, although only the name of

62 Located at 30 'Abd al-Khaliq Tharwat Street.

63 Some of his drawings for the Villa Delort de Gléon entered the Musée d'Orsay in 2000, as mentioned in the introduction. his two assistants, Charles Guimbard and Marcel Gouron-Boisvert, were recorded in its foundational inscription (Fig. 121); he probably contributed preliminary ideas. He subsequently worked on his own residence in Cairo, a highly original achievement, carried out in $1875^{-76}$. The facades were plainer than the ones at Delort de Gléon's or Saint-Maurice's, while the interiors displayed a subtle assemblage of material, pattern and colour, unfortunately lost to the present beholder as the composition is mainly known today through black and white photography. The sitting-room was designed to accommodate a large salvaged ceiling, possibly from the seventeenth or eighteenth century; many doors had old inlaid and carved panels repurposed in modern frames. (Fig. 122 and 


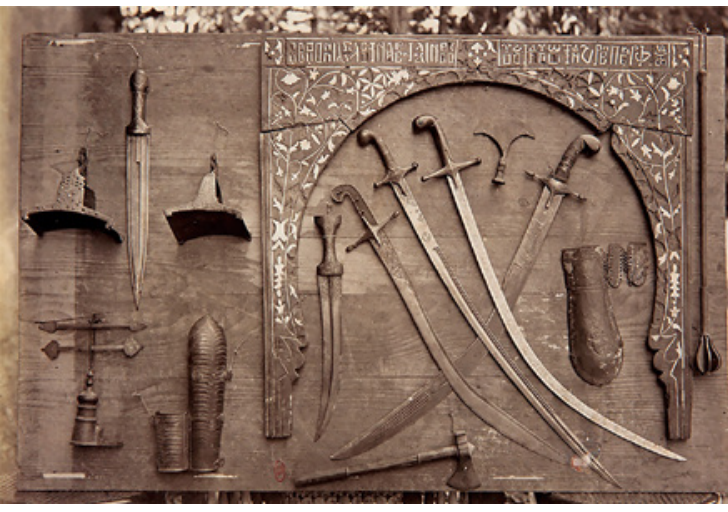

FIGURE 117

Beniamino Facchinelli, Armi antiche (Cairo). Arms from Ambroise Baudry Collection together with a dated Coptic arch made of Ancient Egyptian reused carved wood. Arch is Louvre E 32578. Mounted albumen print. $24 \times 16 \mathrm{~cm}$. Raccolta artistica di fotografie sull'architettura araba, ornati ecc. dal XII ${ }^{\circ}$ alXIII ${ }^{\circ}$ secolo fotografia italiana del Cav. B. Facchinelli, Cairo (Egitto), MDXXXLXXXVII [sic: XXX for CCC, 1887], f. 149 PARIS, BIBLIOTHÈQUE DE L'INHA, FOL PHOT 065

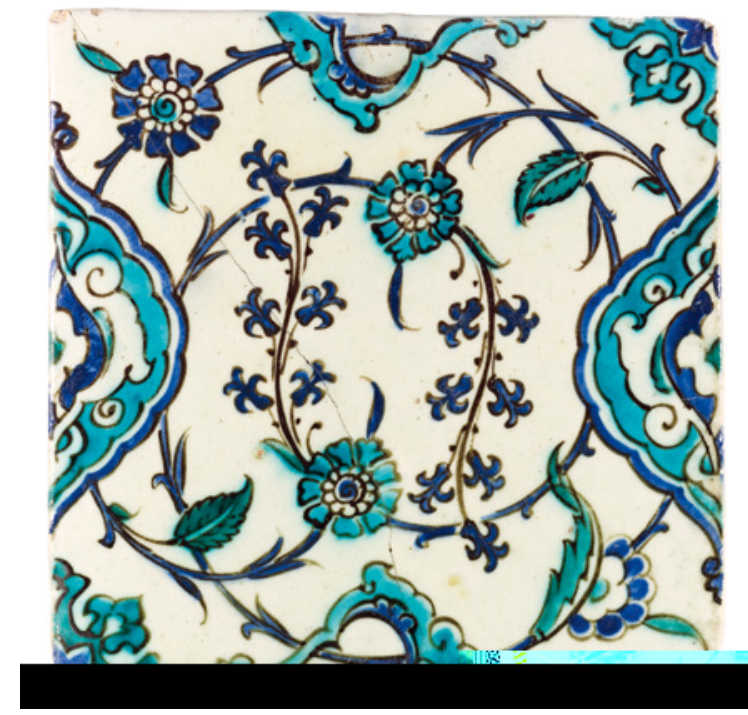

FIGURE 118 An Iznik tile from the large collection of specimens from Cairo, Rashid and Damascus assembled by Ambroise Baudry between 1871 and 1886 . Fritware, underglaze painting. $25.1 \times 25.1 \mathrm{~cm}$ PARIS, MUSÉE DU LOUVRE, DÉPARTEMENT DES ARTS DE L'ISLAM, ANCIENNE COLLECTION AMBROISE BAUDRY, OA 4047/66

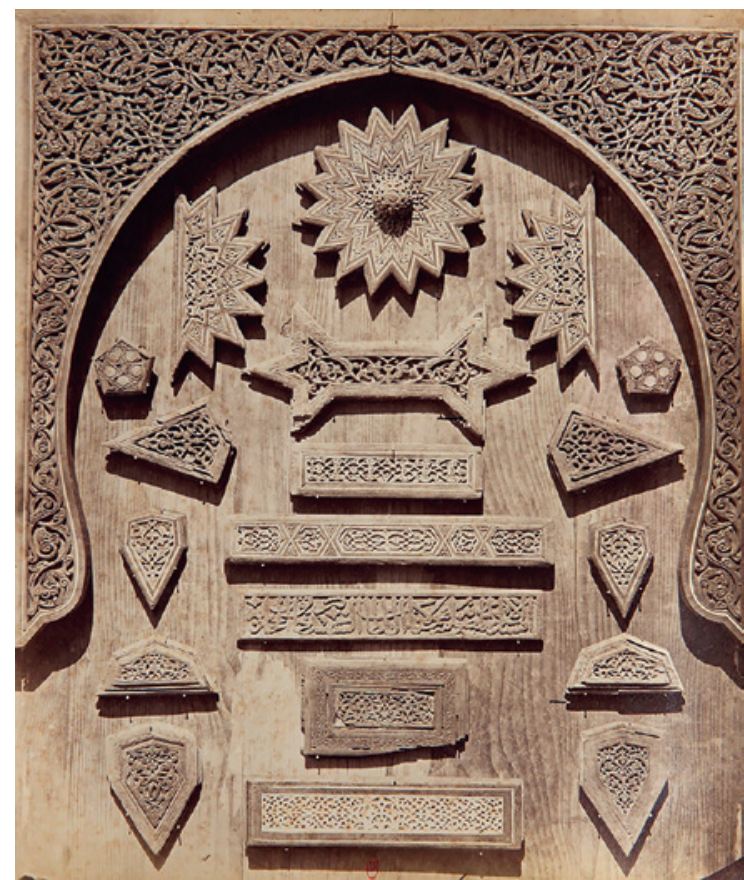

FIGURE 119

Beniamino Facchinelli, Ornato e tabourets (Cairo). Carved panels from the collection of Ambroise Baudry, some of which are currently in the collection of the Metropolitan Museum of Art in New York. Mounted albumen print. $21 \times 24 \mathrm{~cm}$. Raccolta artistica difotografie sull'architettura araba, ornati ecc. dal XII ${ }^{\circ}$ al XIII ${ }^{\circ}$ secolo fotografia italiana del Cav. B. Facchinelli, Cairo (Egitto), MDXXXLXXXVII [sic: XXX for CCC, 1887], f. 165 PARIS, BIBLIOTHÈQUE DE L'INHA, FOL PHOT 065

123) Some walls were covered with a combination of coloured plaster casts and bi-chromatic woodwork. Doors were framed with a row of Iznik tiles, elegantly fixed with discrete clips, and harmoniously mixing cobalt, turquoise and green tones, with some yellow and spots of brownish red.

Baudry designed most of the furniture, which in many cases incorporated historic fragments. Like Saint-Maurice, Baudry had a carpenter working with him at his house. In this case, it was a craftsman of Maltese origin, a Peppe Gliveu, who later established his own business in "Arabesque style furniture" [entrepreneur de travaux de menuiserie en style arabesque in French, or sina baladī in 


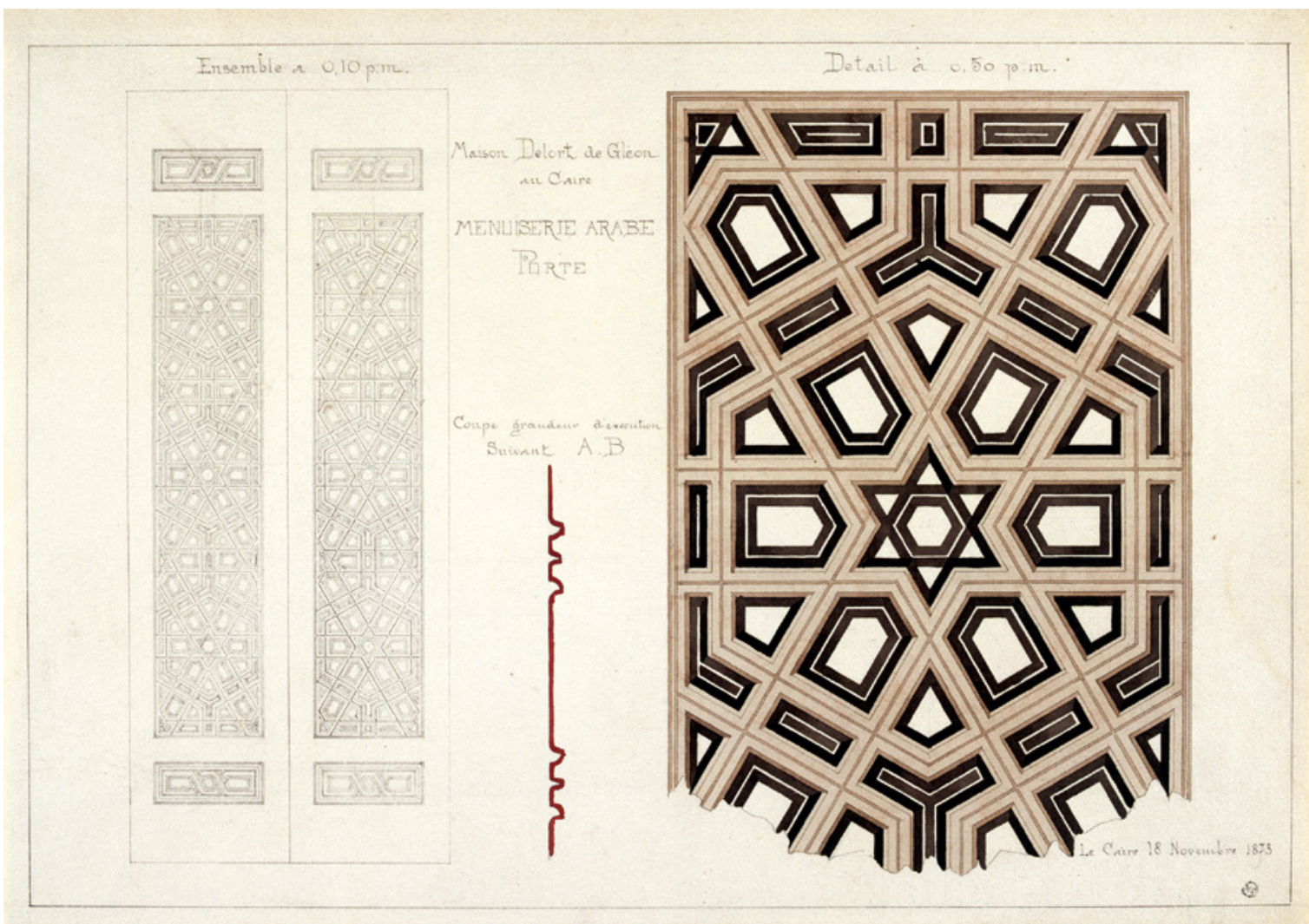

FIGURE 120 Ambroise Baudry, Maison Delort de Gléon au Caire, menuiserie arabe, porte, 18 novembre 1873. ['Arab' woodwork for the house of Delort de Gléon in Cairo]. Watercolour, red ink and pencil on paper. $32 \times 44 \mathrm{~cm}$ PARIS, MUSÉE D'ORSAY, ARO2000-381 (PHOTOGRAPH BY HERVÉ LEWANDOWSKI)

Arabic, literally native craftsmanship] ${ }^{64}$ Of particular notice, is an overmantel characterised by an upper pair of two arcaded openings topped by a crenellation, historic carved wood and inlaid ivory, and Arabic inscribed plaques. The two symmetrical inscriptions, possibly modern copies, name the fourteenth-century Sultan Barquq, while the central one is Qu'ran 22:77, the penultimate verse of sūrat al-Hajj:

64 The "master of cultured restoration", as Baudry nicknamed him, appears in several letters, e.g. Letter of Ambroise Baudry to Ernest de Blignières, 22 May 1883 (Private collection, correspondance Baudry); Cairo, Institut français d'archéologie orientale, Archives administratives, Invoice of Peppe Gliveu, dated 22 February 1898.

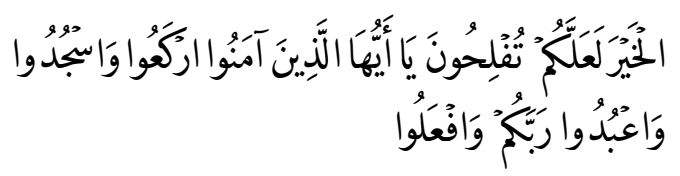

O men, bow you down and prostrate yourselves, and serve your Lord, and do good; haply so you shall prosper.

The piece stood on top of a chimney in an adjacent recess of the house's main sitting-room. (Fig. 124)

A comment made by his brother Paul, after discovering the house during a visit to Cairo in 1876 , offers crucial evidence to critically locate the artistic genre and rationale of Baudry's design:

La maison d'Ambroise est un bijou. Nous serions riches si l'immeuble était situé dans 


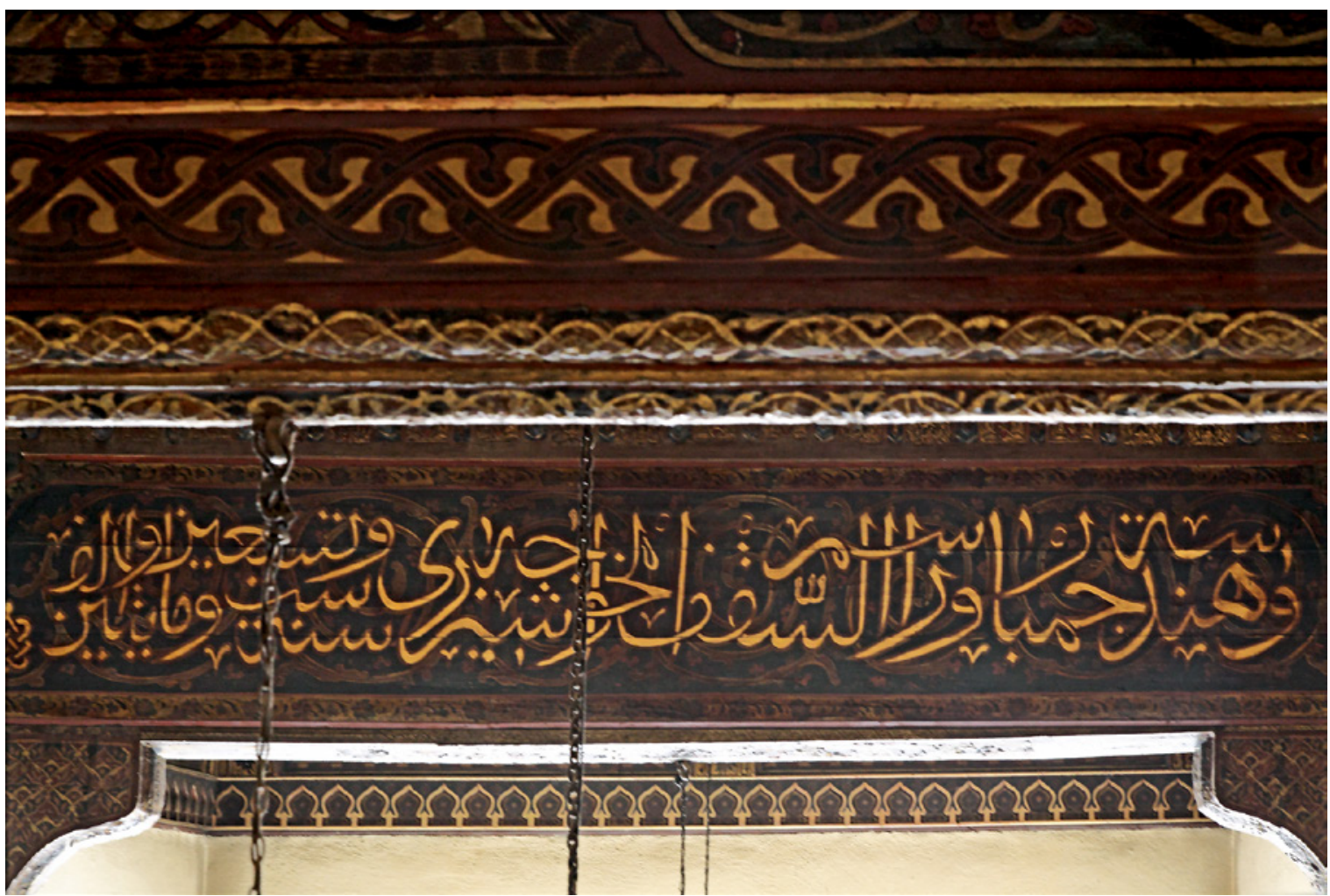

FIGURE 121 Second part of the foundation inscription bearing the name of the artist who designed the ceiling of Saint-Maurice's house

PHOTOGRAPH BY BLAS GIMENO RIBELLES, 2012

les environs du boulevard St Germain, ou simplement aux Batignolles, les portes et les plafonds, les marbres et les faïences viennent des palais du 16ème siècle, c'est un Cluny arabe. ${ }^{65}$

The phrase "an Arab Cluny" leaves no doubt as to the matrix from which Baudry's architectural recreation proceeded: it explicitly echoed the restoration and refurnishing, from 1839 onwards,

65 Paris, Bibliothèque de l'École des Beaux-arts, Correspondance entre Charles et Louise Garnier et Paul Baudry, 2d part, 1873-1885, Mss 742, pièce 97, Letter of Paul Baudry to Louise Garnier, 22 December 1876: "Ambroise's house is a gem. We would be rich if the building stood in the surroundings of boulevard SaintGermain, or simply at the Batignolles; the doors and ceilings, the marbles and tiles, come from 16th century palaces, it is an Arab Cluny." [My translation] of the Abbey of Cluny (later Musée de Cluny), one of the very few medieval mansions that were left in Paris, already mentioned in Chapter 2. It inscribes Baudry's Cairene dwelling into manifestations of the French "fever of analogy," a movement that aimed to make the (medieval) past live again. The craze reached its apogee in the "living museums" displayed at Universal expositions with animations by costumed performers, and live recreations of past entertainments and activities. ${ }^{66}$ An initially exclusive pursuit soon transformed into a most popular one.

66 Elisabeth Emery and Laura Morowitz, "From the living room to the museum and back again: The collection and display of medieval art in the fin de siècle," Journal of the History of Collections 16, no. 2 (November 2004): 285-309. 


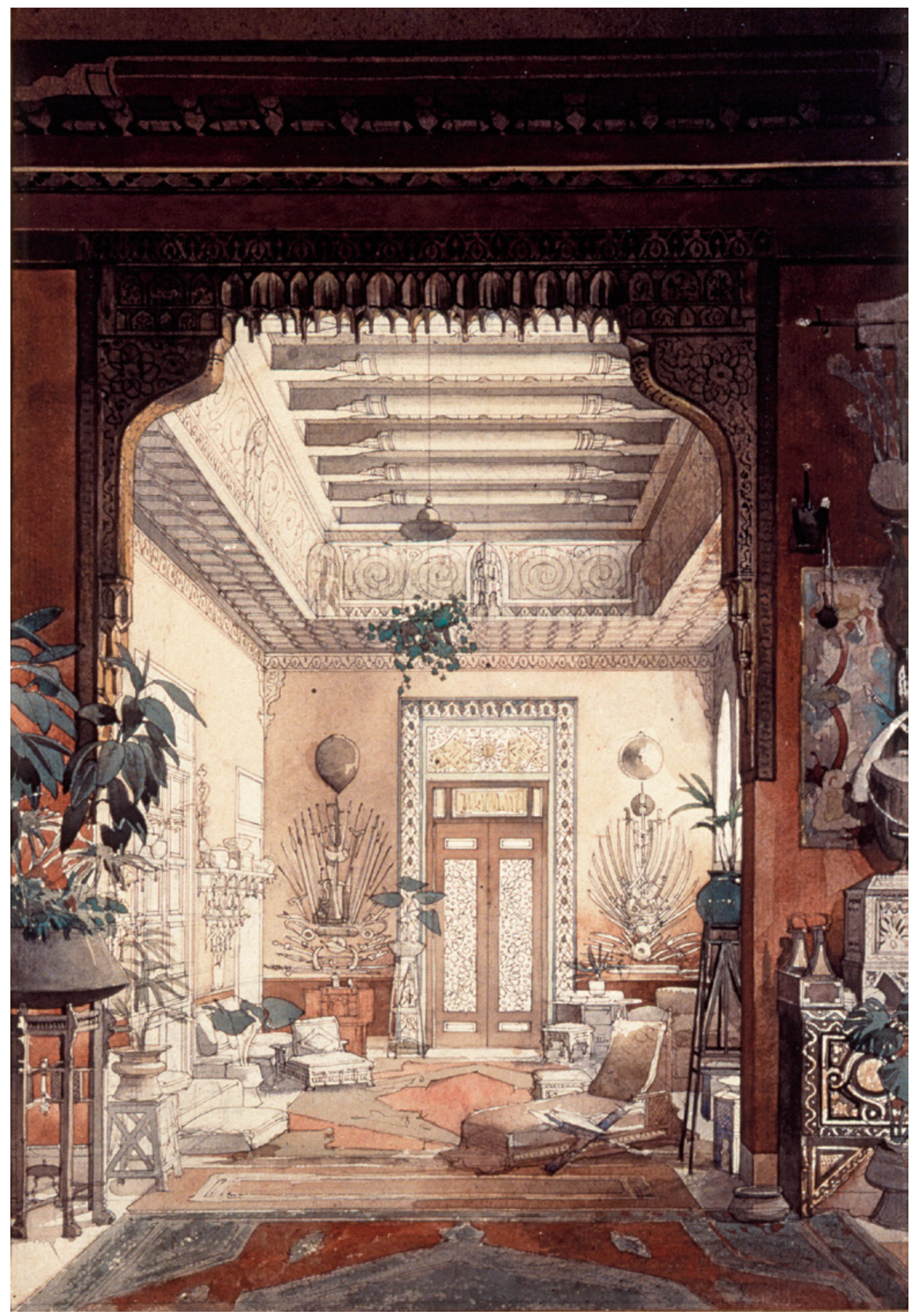

FIGURE 122

Ambroise Baudry, Untitled [Grand parlour of his house in Cairo], undated [after 1876].

Watercolour and pencil on paper. $39 \times 33 \mathrm{~cm}$

CURRENT LOCATION UNKNOWN 


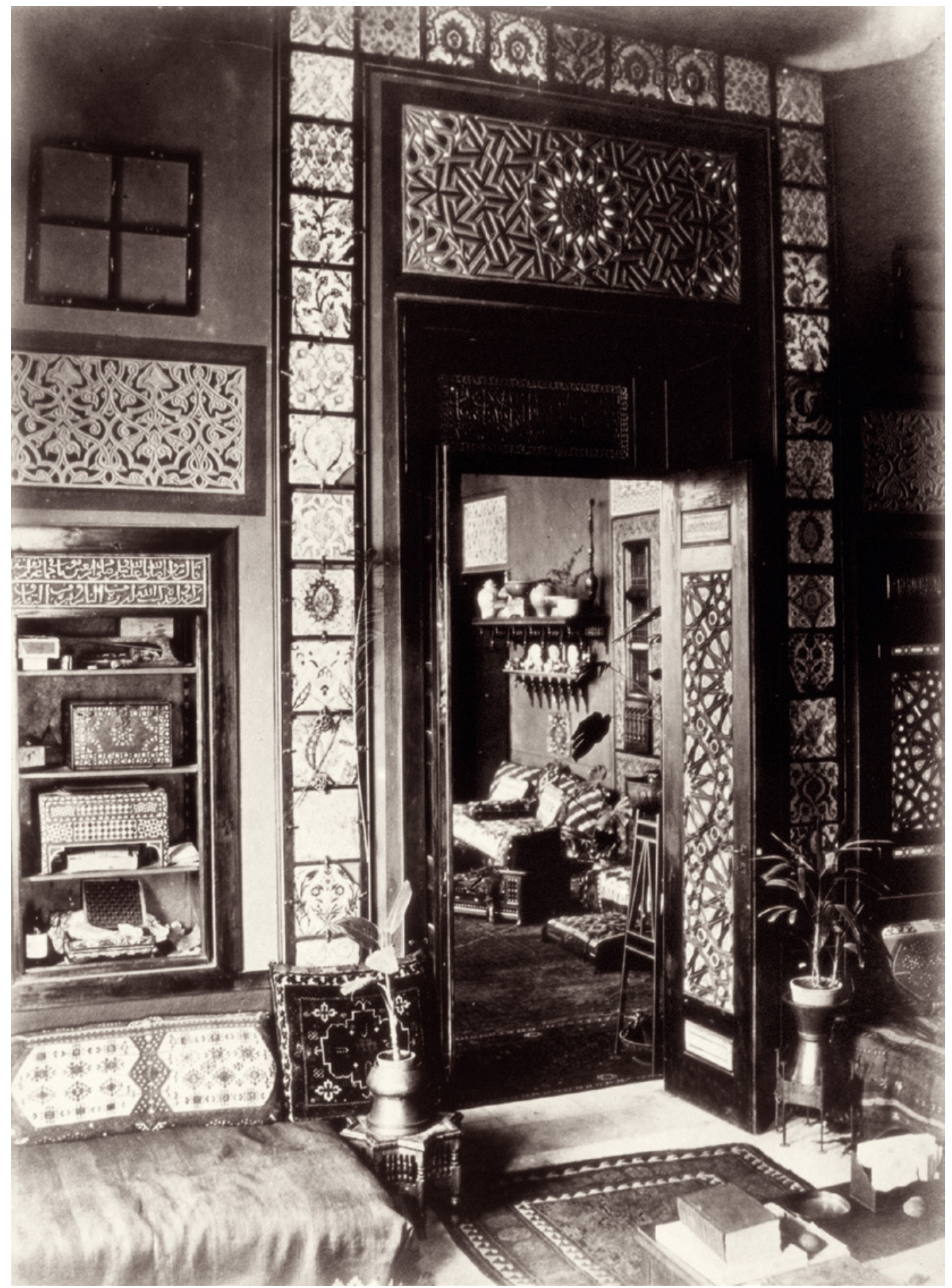

FIGURE 123 Anonymous, Untitled [A corner of Baudry's studio at his house in Cairo], undated [after 1876] AUCTIONED AT PARIS-DROUOT MONTAIGNE, ARTS D'ORIENT, PARIS, 7 JUNE 1999, LOT 145. CURRENT LOCATION UNKNOWN 


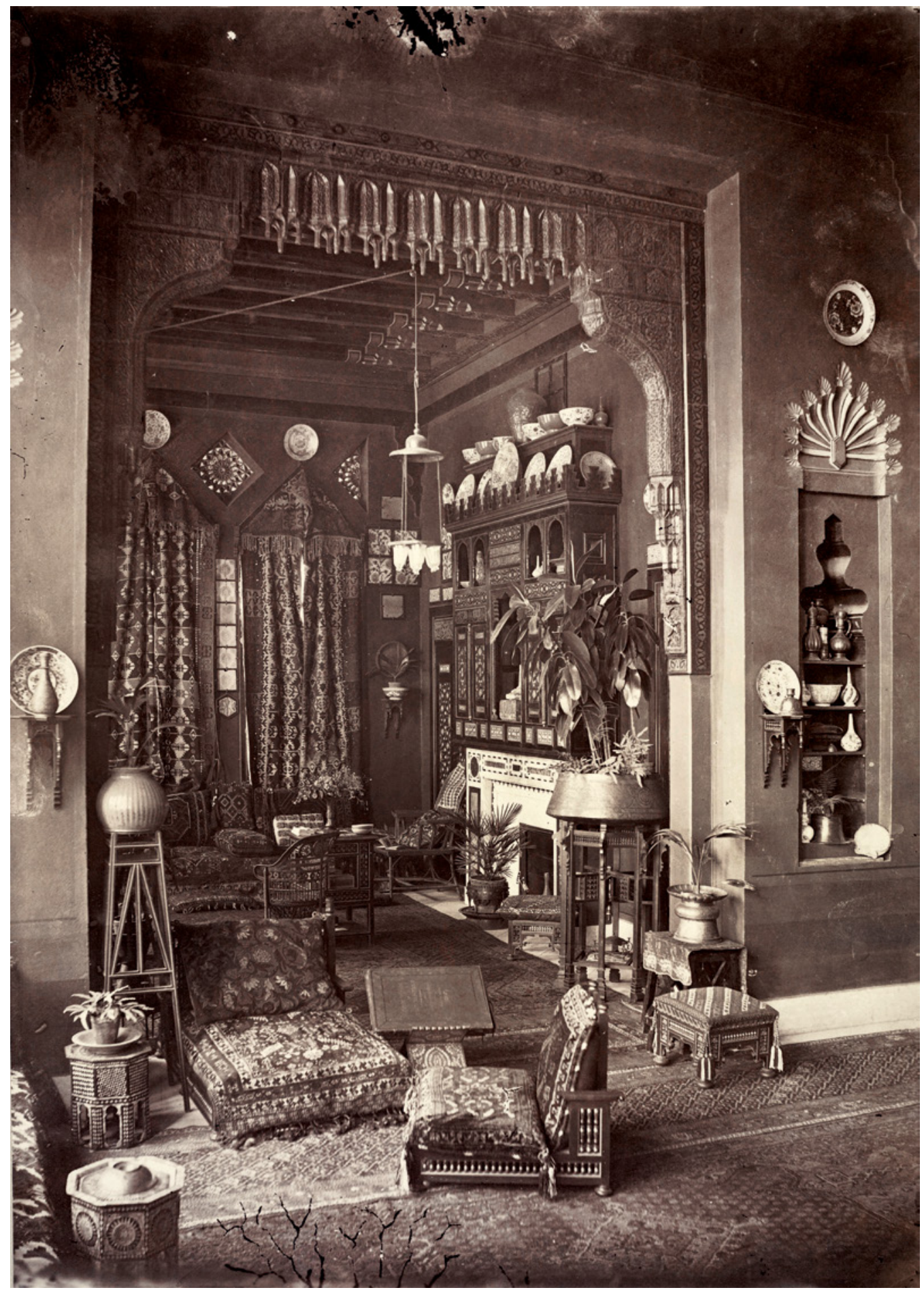

FIGURE 124 Anonymous. Cairo. Egyptian home (interior). [A recess at Ambroise Baudry's house in Cairo]. The overmantel with Mamluk carved panels features in the far centre of the photograph. Albumen print. $40.5 \times 28 \mathrm{~cm}$ CORNELL UNIVERSITY LIBRARY, ANDREW DICKSON WHITE ARCHITECTURAL PHOTOGRAPHS, 15/5/3090.01492 


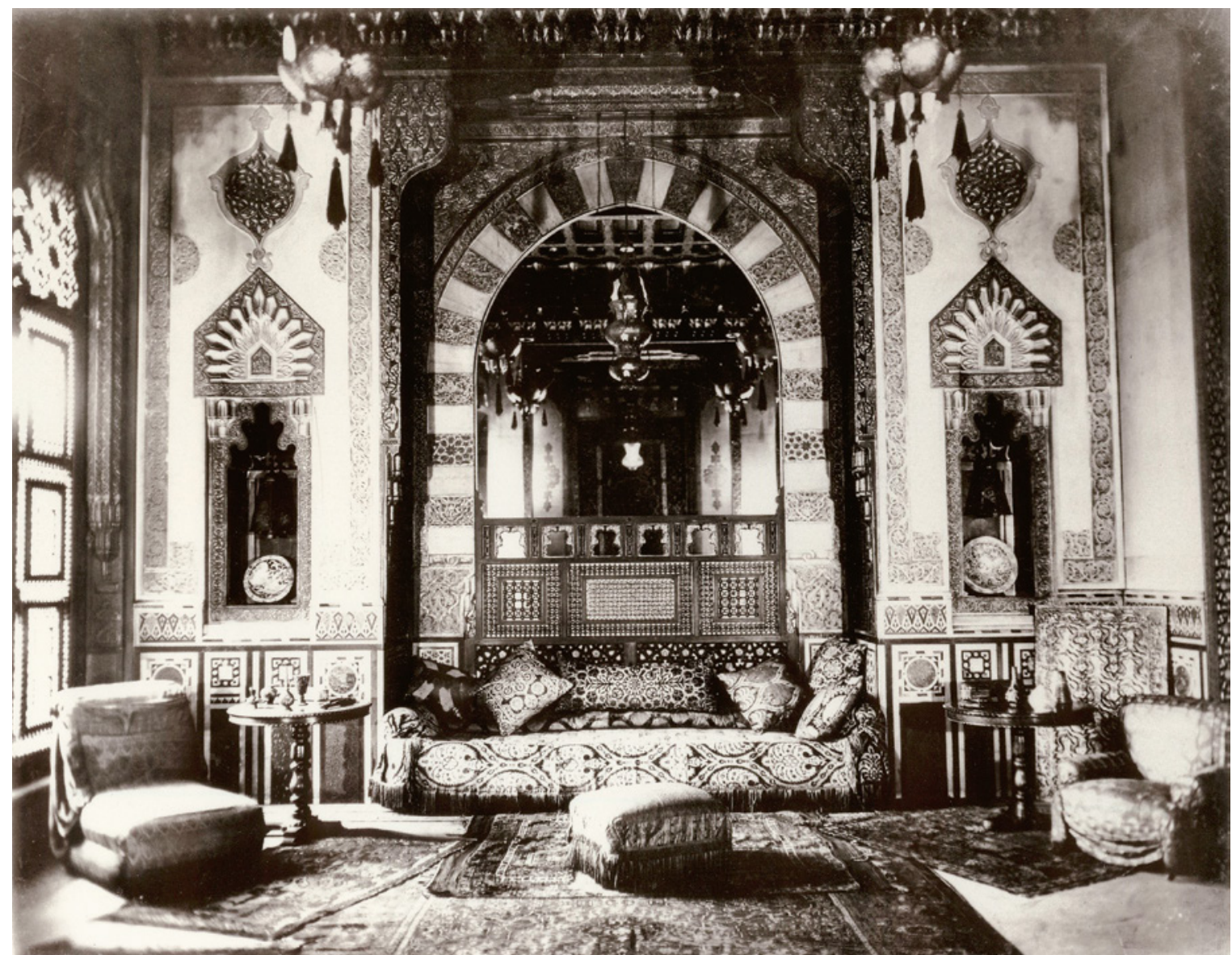

FIGURE 125 Anonymous, Untitled [Edmond de Rothschild's smoking room in Paris], designed by Ambroise Baudry in 1889-93. The room is no longer extant.

WADDESDON MANOR ARCHIVES

Historical recreation became Baudry's specialty. He arranged similar interiors for his friend Ernest de Blignières in Cairo (in 1880) and in Brittany (1882). From 1889-92 he worked on a sophisticated Mamluk style smoking room for Islamic art collector Edmond de Rothschild (1854-1934) in Paris. (Fig 125 and 126) In this instance, the architect furthermore provided his client with "ancient Arab ivory panels" at a cost of 25,000 francs, possibly inserted in the panel behind the central sofa. ${ }^{67} \mathrm{In}$ 1892, Baudry extended the technique of accommodating salvage into new constructions in France. For instance, he reinstalled seventeenth-century

67 Private collection, Baudry's accounts' ledger, 53. gilded and sculpted French panelling in a modern mansion he designed in the vicinity of Le Mans. ${ }^{68}$ Historic salvage brought pedigree to interiors, together with exclusivity. It was not an effortless pursuit, nor one reserved for exotic settings and recreations. It was a specific architectural genre, which developed into a successful industry from the 19oos onwards, particularly in the United States, in the hands of French decorators such as Georges Hoentschel (1855-1915), but

68 Crosnier Leconte and Volait, L'Égypte d'un architecte, 113-14. 


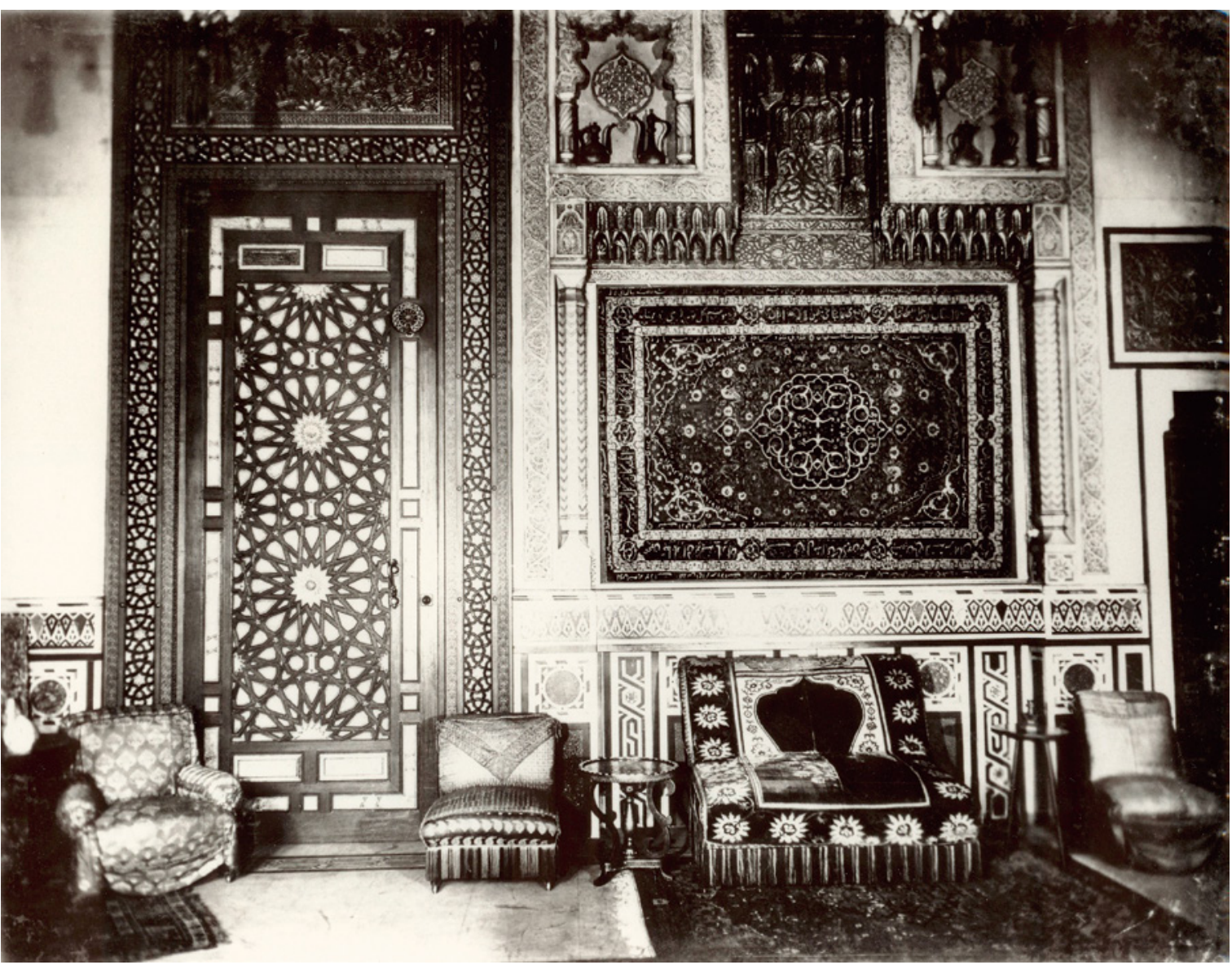

FIGURE 126 Anonymous, Untitled [Edmond de Rothschild's smoking room in Paris], designed by Ambroise Baudry in 1889-93. Of note is the display of rugs on the wall.

WADDESDON MANOR ARCHIVES

also American designers, starting with architect Stanford White (1853-19o6) ${ }^{69}$

\section{The Living Culture of Reuse in Egypt}

The reuse of salvage in architecture, or its insertion into modern furniture, is at odds with current preservation principles promulgated at

69 Daniëlle Kisluk-Grosheide et al., eds., Salvaging the Past: Georges Hoentschel and French Decorative Arts from the Metropolitan Museum of Art (New York: Bard Graduate Center, 2013); Wayne Craven, Stanford White: Decorator in Opulence and Dealer in Antiquities (New York: Columbia University Press, 2005). an international level by multilateral organisations such as UNESCO. Preservation specialists and activists tend to forget that the tradition of reuse and the recycling of historic fragments are centuries-old practices that cut across most cultures and times. The repurposing of historic material enjoyed remarkable momentum in Medieval and Early Modern Europe. ${ }^{70}$ In more recent times, it has inspired art worldwide throughout the past century; lately the celebrated Chinese artist $\mathrm{Ai}$ Weiwei (b. 1957) has experimented with it in the

70 Pierre Toubert \& Pierre Moret, eds., Remploi, citation, plagiat: Conduites et pratiques médiévales (Madrid: Casa de Velázquez, 20o9). 
utmost provocative manner. ${ }^{71}$ Second-hand reuse, labelled "upcycling" in the fashion industry, is nowadays being promoted for ecological concerns.

Nor was the concept of salvage alien to Egypt. Indeed, its Egyptian history is extended and substantial. Reuse has been widely practiced since Antiquity; and it continued to be after the rise of Islam. Its driving forces were adornment, apotropaia, or simple construction, e.g. foundation filling. ${ }^{72}$ It is still a living tradition, although its contemporary manifestations have never been properly studied. In any event, aesthetic interiors made out of salvage in Cairo from the $1870 \mathrm{~s}$ onward cannot be comprehended only within the Cluny craze; they need to be considered along the grain of this Egyptian cultural background as well.

\subsection{Life Cycles of Salvage}

The local afterlife of Baudry's work in Cairo is a first indication that they fit into a domestic pattern of reuse. The various fates of what he designed in architecture and furniture offer a significant measure. The overmantel he created for his Cairene residence is currently displayed in the galleries devoted to the Mamluk dynasties in the Museum of Islamic Art in Cairo. (Fig. 127) When it was catalogued for the reopening of the Museum in 2010, the furniture was deemed a "cupboard" but its form caused some perplexity, as "nothing similar [had] ever been found."73 The given provenance in the guidebook of the Museum is the collection of Prince Yusuf Kamal (1882-1967). As a matter of fact, the portable piece adorned one of the rooms at his palace in Matariyya, as a late 1930 s

71 Ai Weiwei et al., Ai Weiwei: Dropping the Urn: Ceramic Works, 5000 BCE-2010 CE (Glenside, Pa.: Arcadia University Art Gallery, 2010), exhibition catalog.

72

For an overview and a case study, Iman R. Abdulfattah, "Theft, plunder, and loot: An examination of the rich diversity of material reuse in the Complex of Qalāwūn in Cairo," Mamlūk Studies Review 20 (2017): 93-132. Cairo: Museum of Islamic Art: 23767; Bernard O'Kane, ed., The Illustrated Guide to the Museum of Islamic Art in Cairo, with contributions by Mohamed Abbas and Imam R. Abdulfattah (Cairo: The American University in Cairo Press, 2012), 134. photograph reveals. ${ }^{74}$ (Fig. 128) The Mamluk style room where it was placed represented a later addition to a building that had been erected in 1908-21 on designs by Slovenian architect Anton Lasciac. ${ }^{75}$ As Baudry's house was demolished in 1935 or 1936, after its purchase by the famous antique dealer Kevork Ispenian, who had stores in Cairo and Istanbul, ${ }^{76}$ it can be safely assumed that Yusuf Kamal bought the salvaged piece of furniture from Ispenian for his new room. In the process, its crenellations were lost. The transfer to the Museum of Islamic Art took place after the Prince's death. He had bequeathed his collections to the Museum during his life time, while reserving the right to continue using them; ${ }^{77}$ they reverted to the Museum on his death in 1967. Consequently, his Mamluk style room was emptied, and the unique cupboard went to the Museum. The full history of Baudry's piece was by then lost, which explains its misplacement. Hopefully, the artwork will at some point benefit from, and indeed contribute to, the current reconsideration of the boundaries of Islamic art and architecture. There is a recognised need among Islamic art scholars for enlarging the temporal extension of the canon in order to accommodate nineteenth-century art and architecture. ${ }^{78}$ Mamluk Revival specimens, ${ }^{79}$ and within that genre the sub-category represented by modern pieces incorporating historic salvage,

74 Roma, Library of Accademia di San Luca, Album Architetto Antonio Lasciac. Cairo-Egitto [n.d., given in 1939], 86 plates, 1688bis, pl. 33 .

75 Volait, Fous du Caire, 216.

76 Nantes (France), Archives rapatriées des postes, Le Caire, Ambassade, 353Po/2/406, G.D. [Gabriel Dardaud?], "Trois vieilles maisons du Caire," La Bourse égyptienne, 15 April 1937 (clipping).

77 Gaston Wiet, "Le musée national de l'art arabe," L’Art vivant $\mathrm{v}$ (15 January 1929): 53-7.

78 Barry Flood \& Gülru Necipoğlu, "Frameworks of Islamic Art and Architectural History: Concepts, Approaches, and Historiographies," in A Companion to Islamic Art and Architecture, eds. Flood \& Necipoğlu (Hoboken, NJ: Wiley Blackwell, 2017), I: 2-56.

79 Marcus Millwright, "Reviving the Past and Confronting the Present: Crafts in Syria and Egypt, c. 1875-1925," The Journal of Modern Craft 13 (2020): 7-21. 


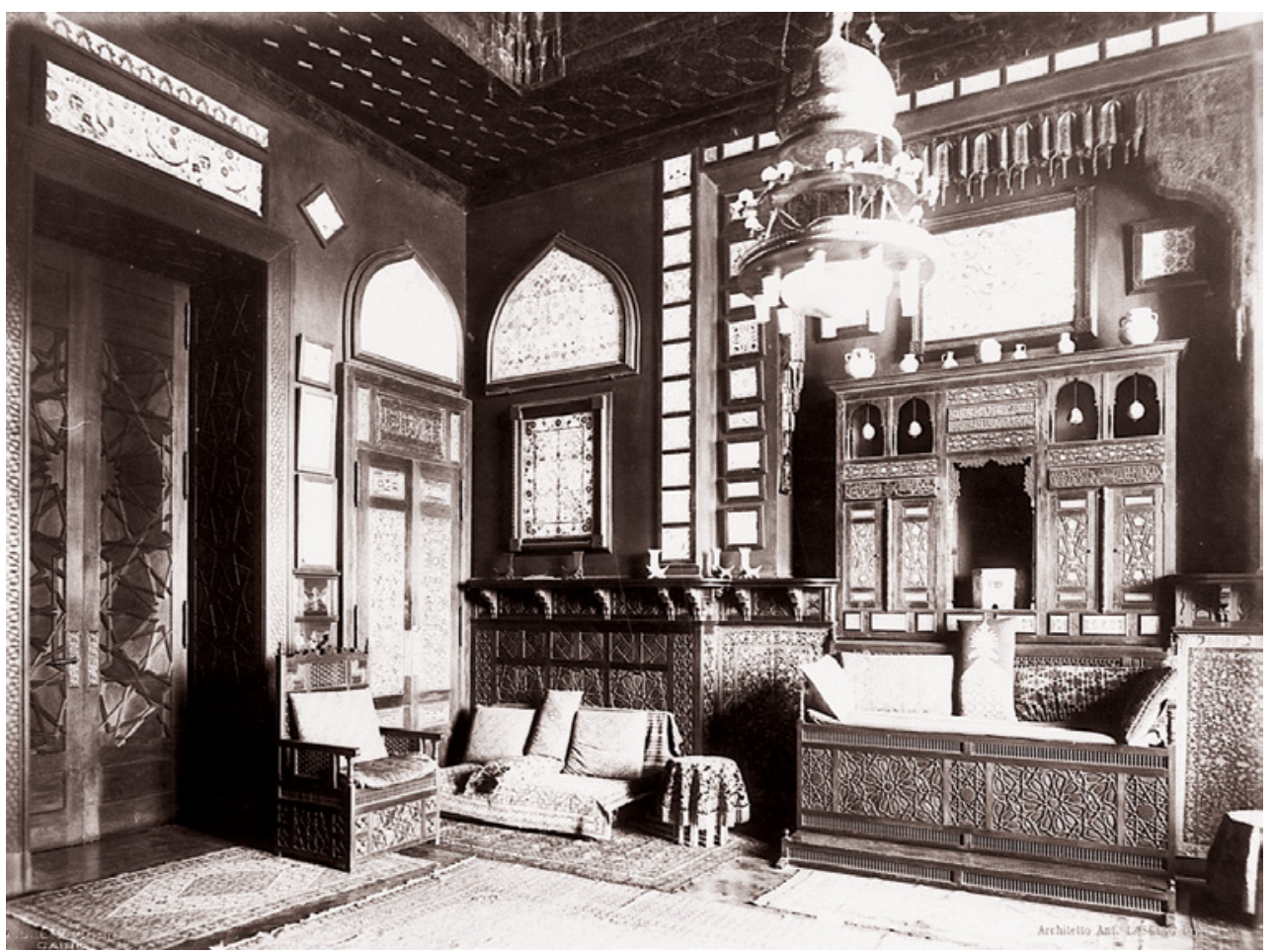

FIGURE 127

A. Del Vecchio, Untitled [Room at Yusuf Kamal's palace in Matariyya, designed by Anton Lasciac], c. 1935-36. Mounted albumen print. No dimensions provided. Album Architetto Antonio Lasciac. Cairo-Egitto

ROME, LIBRARY OF ACCADEMIA DI SAN LUCA, 1688BIS, F. 34

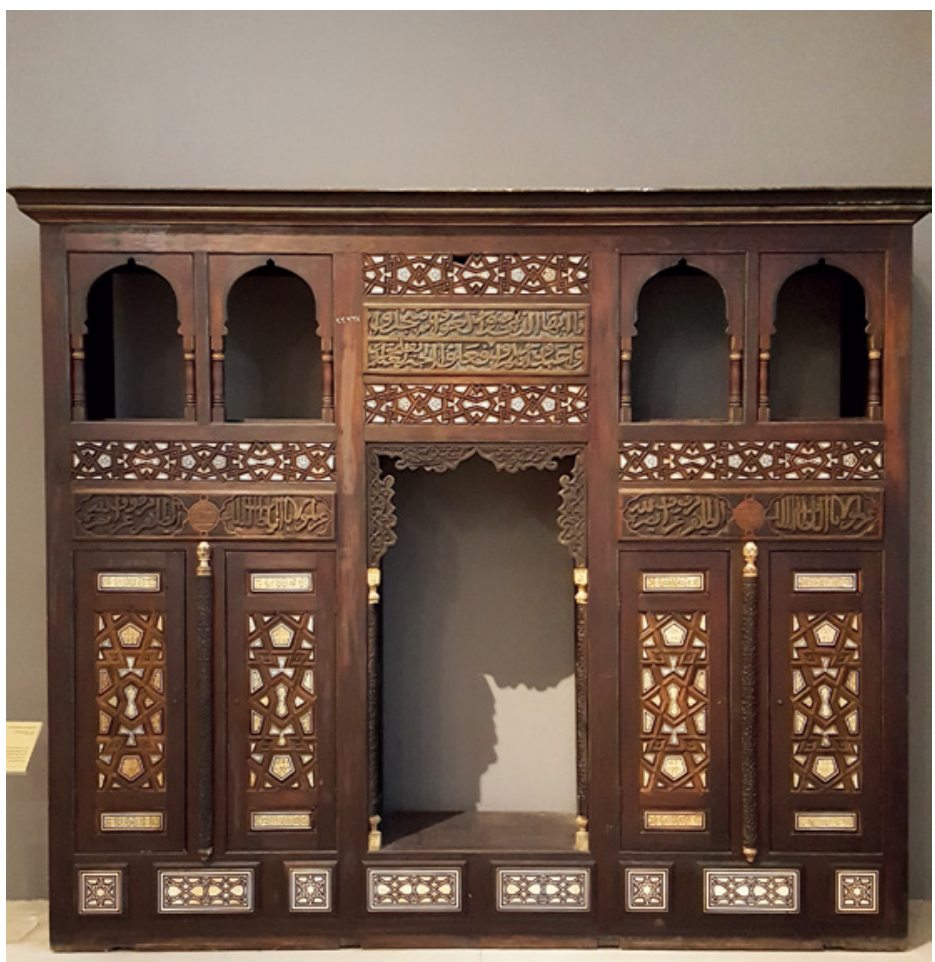

FIGURE 128

Overmantel designed by Ambroise Baudry in $1875^{-76}$ with fourteenth-century carved polygons, currently on view in the Mamluk galleries of the Museum of Islamic Art in Cairo (23767) PHOTOGRAPH BY THE AUTHOR, 2017 
are perfect candidates. These might be considered composite, but what art is not in some way? In any case, Mamluk art repurposed in modern artefacts created a very significant line of production, particularly in Egypt. It led to fine pieces. Beyond their historical and artistic values, the intercultural nature of such mixed-period artworks is worth museological attention.

To this day, these pieces have seldom attracted such consideration. Other nineteenth-century examples of modern woodwork incorporating Mamluk panels and inscriptions are experiencing a fate similar to the afterlife of Baudry's overmantel: their modern history is being erased. This is the case of a couple of doors that were auctioned in London in $2016 .{ }^{80}$ They had been made for another French expatriate in Cairo from 1879 to 1900, the lawyer Octave Borelli (1849-1911), a close acquaintance of Delort de Gléon, who will be encountered again in the following chapter. The mixed-period doors were installed in his house in Cairo's new quarters. Upon his return home, Borelli mounted the doors in an Orientalising parlour at the large residence he had built in the heights of the summer resort of Saint-Tropez in southern France. The doors were bought by the Islamic Arts Museum Malaysia in Kuala Lumpur at the London sale, and loaned as Mamluk doors for the new British Museum's Islamic galleries funded by the Malaysian Albukhary foundation. Their current labels make no references to their repurposing and reframing, which is again puzzling to the viewer for the nineteenth-century Gothic style framing of the two leaves is quite prominent. ${ }^{81}$

Larger pieces from Baudry's house survived too. His Cairene residence provided the Ottoman ceiling that Prince Yusuf Kamal had installed in his own Arab Room at Matariyya. A second ceiling went, together with one of the facades and a large wooden balcony, to the villa that the antique

\footnotetext{
8o Arts of the Islamic World, Sotheby's London, 2o April 2016, lots 84 and 86.

81 IAMM 2016.12.1, in 2020 on show in room 43a at the British Museum in London (lot 84 of Sotheby's sale L16220, 20 April 2016).
}

dealer Kevork Ispenian was building in 1936 at 29 Pyramids Road. ${ }^{82}$ Together with the other historic pieces in the house, all duly registered in the inventories of the Museum of Islamic Art in Cairo, the architectural salvage from Baudry's house was ultimately looted in 2011, and consequently embarked on a new journey. ${ }^{83}$ Baudry's salvage and work thus continued to live since the 193 os within a world of dealers and patrons; their motion recently resumed. The prime change was, and is, that they now circulate into a local, or possibly regional, eco-system. Ultimately, one piece reached museum status in Cairo, albeit due to a misunderstanding.

Part of Saint-Maurice's salvage survived as well, but in a radically different context. As mentioned already, much of it was specifically reinstalled in a building designed to incorporate it in the new French diplomatic premises at Giza. Villa Delort de Gléon is the only one still standing in its initial location on 30 'Abd al-Khaliq Tharwat Street, though made almost invisible today by the many encroachments that happened over the years upon its original surrounding garden. After Delort de Gléon's return to France, the property passed to Muhammad al-Shawarbi, the heir of a large landowning family in the province of Qalyubiyya; ${ }^{84}$ it was made a waqf in 1908.85 An Islamic style house, designed for a European bachelor, thus came into the hands of an affluent Egyptian household. It is not clear if and when the house was used by the family. As a member of the Legislative Council, Muhammad al-Shawarbi may have occupied it as his pied-à-terre in Cairo. He might also have invested in the property for renting purposes. In

\footnotetext{
82 Mercedes Volait, Fous du Caire, 217-20.

83 Omar El Adl, "Systematic ruin of Egypt's antiquities in Haram," Daily News Egypt, 3 January 2013; [https:// cairobserver.com/post/42575456931/destruction-alertvilla-ispenian], accessed 25 May 2020.

84 The Al-Shawarbi family originated from the Hijaz and had emigrated to Egypt in the thirteenth century; Raouf Abbas and Assem El-Dessouky, The Large Landowning Class and the Peasantry in Egypt (1837-1952) (Cairo: AUC Press, 2012), 70.

85 Personal communication from Maître Saad Fakhry Abdel Nour, 1998.
} 


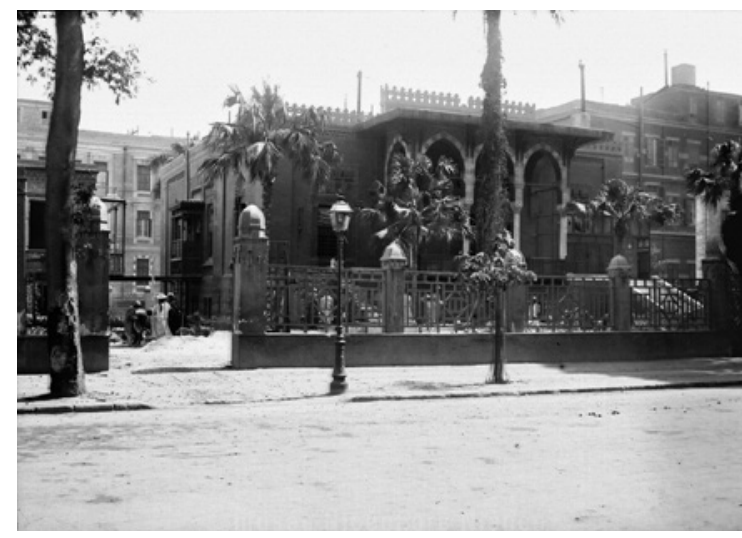

FIGURE 129 Georges Blanchard, L'Agence d'Italie au Caire, 1908. [Villa Delort de Gléon in Cairo while rented by the Italian Embassy, 19o8]. Glass plate. $13 \times 18 \mathrm{~cm}$ CHÂLON-SUR-SAONE, MUSÉE NICÉPHORE NIÉPCE, 96.33.310/308

the early 190os, the building housed the Italian Consulate. (Fig. 129) In the 1920s, it served as premises for the journal al-Siyāsa [The Politics], the main media outlet of the Constitutional Liberals, one of the parties that defended a moderate nationalist line. The house seems to have been abandoned in the 196os. It was refurbished in 1995 and since then serves as a warehouse for trading companies. Interestingly enough, the marble mosaics designed in 1871 by Baudry for surface decoration of the main reception room were then offered as salvage to be bought. ${ }^{86}$ Baudry-designed Mamluk style dados are now adorning a completely different building somewhere in Cairo or in the region. Their life cycle in one place lasted some 120 years; another phase started unfolding some twenty years ago.

\subsection{A Centuries-Old Tradition}

Another way of identifying possible interplays between Baudry's work (and other like it) and local realities is to position them within currents of reuse culture in Egypt. In turn, this implies a better understanding of the history of this culture, for none has been written so far in

86 They were offered for purchase to the author by the administrator of the house. a comprehensive way, encompassing the longue durée. But many instances of Islamic reuse are known. For example, during the first three Islamic centuries, grave stones often move from one tomb to another; it was sufficient to engrave the name of the deceased on the reverse of the slab. This is continuous practice to this day in abandoned cemeteries, such as the Catholic and Jewish cemeteries at Port-Said, or in out-of-use funerary chapels, as is the case at the Terra Santa graveyard in Cairo, where Catholics were buried. ${ }^{87}$ Funerary headstones were also frequently incorporated into monuments or the city walls: "cemeteries served as quarries for construction in town." 88 A threshold stone bearing hieroglyphs welcomes visitors at the khanqā [convent] of Baybars al-Gashankir (1309), as it does in many other Mamluk and Ottoman mosques in the city. The practice was less ideological than talismanic: Ancient Egyptian inscribed stones protected against the evil eye and satanic influences. ${ }^{89}$ Roman and Byzantine buildings in Egypt, and indeed in Palestine, provided a number of mosques in Cairo with stones, engraved or not. A survey conducted on 137 pre-Ottoman monuments in Cairo concluded that in half of them the polychromatic marble mosaics of their dados and floors were Late Antique spolia. ${ }^{90}$ The capitals of the Fatimid Mosque of al-Azhar, consecrated in 972, are all pre-Islamic: some crosses were even left visible to symbolise the victory over Christianity. All display a Corinthian order; the spolia was not

87 Long-neglected graves and their trappings are redistributed to new applicants, personal observation, March 2017.

88 Yusuf Raghib, "Les pierres du souvenir: stèles du Caire de la conquête arabe à la chute des Fatimides," Annales islamologiques 35 (2001): 321-83.

89 Richard Brilliant and Dale Kinney, eds., Reuse Value: Spolia and Appropriation in Art and Architecture from Constantine to Sherrie Levine (Farnham, UK: Ashgate, 2012), 86.

90 James A. Harrell et al., "Reuse of Roman ornamental stones in Medieval Cairo, Egypt," in ASMOSIA VI, Interdisciplinary Studies on Ancient Stone, Proceedings of the Sixth International Conference of the Association for the Study of Marble and Other Stones in Antiquity, Venice, 15-18 June 200o, ed. L. Lazzarini (Padova: Aldo Ausilio - Bottega d'Erasmon 2002), 89-96. 
only ideological, but indeed aesthetic.91 Muslim victories over the Crusaders favoured the despoliation of Christian architecture in the Holy Land from the late thirteenth century onwards. One famous example is the portal from the cathedral of the Holy Cross in Acre that was taken after the capitulation of the town in 1291 and installed ten years later in the Madrasa of Sultan al-Nasir Muhammad in Cairo. Another is the carved corner stones displaying in miniature the Dome of the Rock, the Church of the Holy Sepulchre and the Residence of the Royal Court in Jerusalem, which were placed at the entrance of the Mosque of Sultan Hasan. ${ }^{92}$

Spolia did not only work across confessions: based on the medieval chronicler al-Maqrizi, Wiet links the disappearance of the Fatimid Palaces of Cairo to the Mamluk reuse of their stones. Fatimid figurative woodwork was also appropriated for Mamluk buildings, famously at the Bimaristan of Qalawun in 1284, and five centuries later, at the Mosque of al-Fakahani, which was fully rebuilt in 1736 using Fatimid remnants. The doors at al-Fakahani not only imitate Fatimid woodcarving; they incorporated authentic Fatimid panels, despite (or because of?) its association to Shiism. ${ }^{93}$ Mamluk Sultans moved artefacts from one monument to another: the elaborate monumental bronze door of the Madrasa of Sultan Hasan was famously transferred to the Madrasa of al-Mu'ayyad Shaykh in the early $1400{ }^{94}{ }^{94}$ Several waves of the Black Death, in particular between 1403 and 1405 , increased the ruins in the city, and

$91 \quad$ Marianne Barrucand, "Les chapiteaux de remploi de la mosquée al-Azhar et l'émergence d'un type de chapiteau médiéval en Égypte," Annales Islamologiques 36 (2002): 37-76.

92 Lucy-Ann Hunt, Byzantium, Eastern Christendom and Islam, Art at the Cross Roads of the Medieval Mediterranean (London: The Pindar Press, 1998), I: 337.

93 Jonathan M Bloom, "The 'Fatimid' doors of the Fakahani Mosque in Cairo," Muqarnas: An Annual on the Visual Culture of the Islamic World Xxv (2008): 231-42.

94 Doris Behrens-Abouseif, Cairo of the Mameluks: a History of the Architecture and its Culture (London: I.B. Tauris, 2007), 231. with them, further opportunities for reuse. ${ }^{95}$ But in fact the practice had never stopped: the khanq $\bar{a}$ of Baybars al-Gashankir was famously built in 1309 with materials purchased from three old houses. ${ }^{96}$

Less familiar are instances from the late Ottoman period. An ancestor of the young Sheikh al-Sadat encountered in Chapter 3, Sheikh Shams al-Din, demolished an old maq'ad graced with arches and a marble column at his family's residence, to replace it with an open oratory. A column, with Corinthian capital, features in the courtyard of the house and might be the one reused. He also had a new pavilion built in the 1810s, and placed a marble column at its centre. ${ }^{97}$ What it was intended for is a mystery. One might speculate that the display of a precious ancient object projected wealth and the taste for art. The stone may have been blessed with apotropaic powers. However, displays of ancient pieces were probably common. They recurrently appear in the topographical imagery of modern Egypt. In 1818, a sketch by Pascal Coste depicts a rotunda in the gardens of Omar Bey Baffi, an Italian chemist, whose estate was located in the vicinity of Giza.98 (Fig. 130) In the middle of the circle, stands a column with a Corinthian capital, like a miniature of Pompey's Pillar in Alexandria. Other capitals mark the outer circle and were possibly used as seats. Was it a way to relate to Antiquity? To the Greco-Roman past of Egypt? To a land of layered cultures? Or did they represented a reference to the follies so typical of eighteenth-century British and French landscaping, as suggested by the vegetal pavilion in the background? It was possibly a mix of all of these. What is sure is that ancient stones represented a common sight in city and countryside alike.

95 Julien Loiseau, Reconstruire la maison du sultan, 13501450: ruine et recomposition de l'ordre urbain au Caire (Cairo: Publications de l'Institut français d'archéologie orientale, 2010), I: 119-21.

96 Loiseau, Reconstruire, I: 131.

97 'Abd al-Rahman al-Gabarti, 'Aga'ib al-atar, IV: 190.

98 Baffi was Pascal Coste's first patron. He was made Umar bey by Mehmed Ali, and headed a battalion of French soldiers who had remained in Egypt after the French had left and had passed to the service of Mehmed Ali. Pascal Coste, Mémoires d'un artiste: notes et souvenirs de voyage (1817-1877) (Marseilles: Cayer, 1878), I: 9-19. 


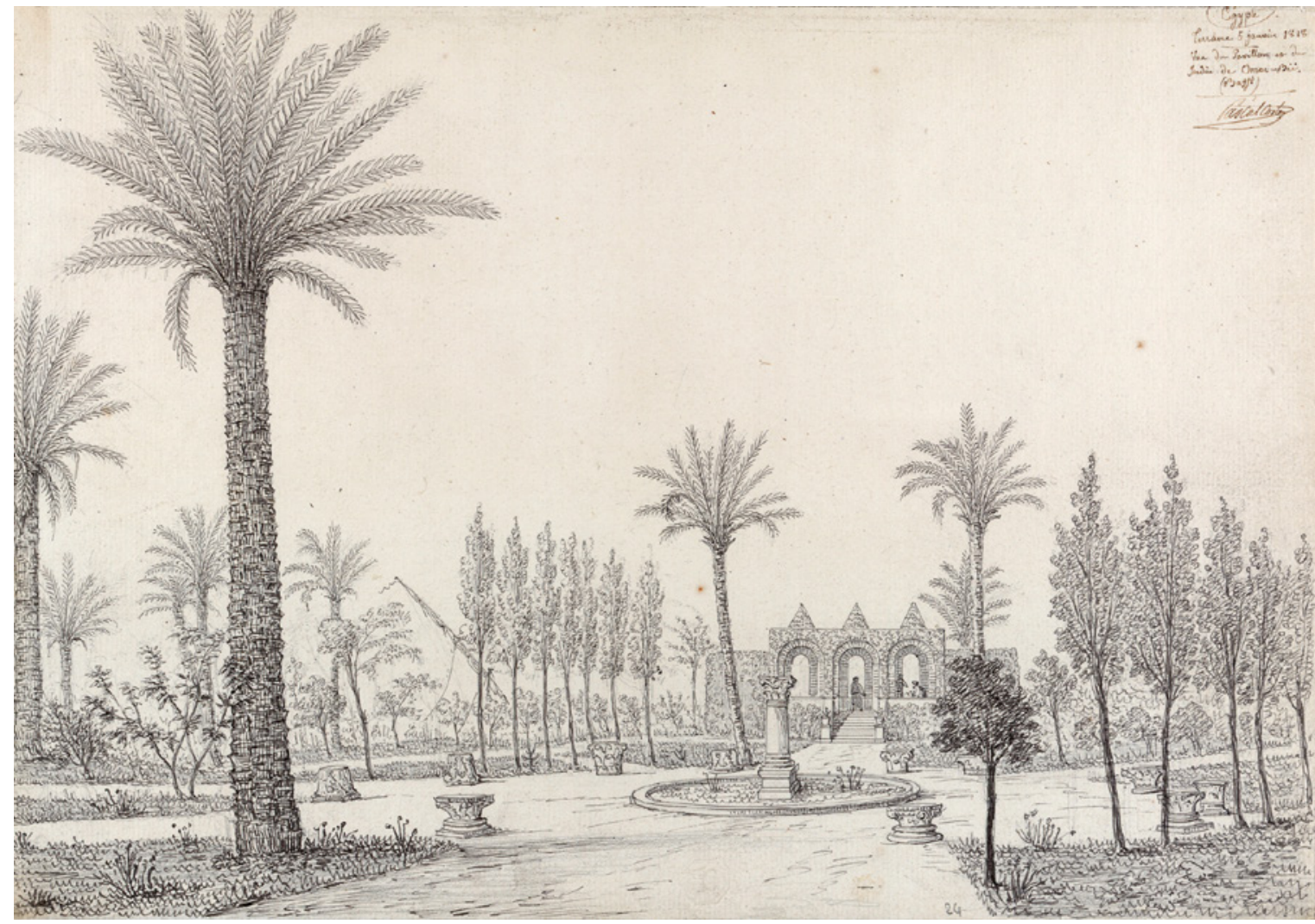

FIGURE 130 Pascal Coste. Vue du pavillon et du jardin d'Omar bey(Baffi) à Terrane, 5 janvier 1818. Anticomania at Omar Bey's estate near Giza. Pencil on paper

MARSEILLES, BIBLIOTHÈQUE DE L'ALCAZAR, MS 1311, F. 24

Ancient Egyptian spolia also had a modern history. Having visited a palace being built in Cairo in 1828, Jean-François Champollion reported that the owner, a minister of Mehmed Ali, had low-reliefs from Saqqara, depicting offerings givers incorporated in a hallway. In other words, the high official displayed the figurative art of the civilisation of the Ancient Egyptians at his house. This would be commonly considered absolute sacrilege today because of preservation concerns. Nor is it in line with the Islamic aniconism we might expect from such a figure. For the young Egyptologist, such appropriation, coming from a man known for opposing Mehmed Ali's reforms, was quite remarkable and encouraging. ${ }^{99}$ It manifested a

99 "C'est un pas fort remarquable, fait par un ministre du Pacha, le plus renommé pour son opposition à la réforme," in Lettres et journaux de Champollion, ed. Hélène Hartleben (Paris: Ernest Leroux, 1909), taste for the Antique and an acceptance of figurative imagery that Champollion equated with progress. The comment offers useful information on local mind-sets and attitudes. Furthermore, it coincides perfectly with current re-evaluations of the artistic deployment of spolia as a reconfiguration of the past meant to convey contemporary messages. ${ }^{100}$ In sum, the topic is worth academic attention rather than judgemental comments on heritage appropriation.

The diverse afterlives of spolia over time in Egypt raise numerous questions and point to experiences and situations that exceed the

Bibliothèque égyptologique $\mathrm{xxxI}, 2^{\mathrm{e}}$ partie, $87-8$ and 116.

Paul Magdalino, "Epilogue: A meditation on the culture of spolia," in Spolia Reincarnated: Afterlives of Objects, Materials and Spaces in Anatolia from Antiquity to the Ottoman Era, eds. Ivana Jevtic and Suzan Yalman (Istanbul: Anamed, 2018), 341-5o. 


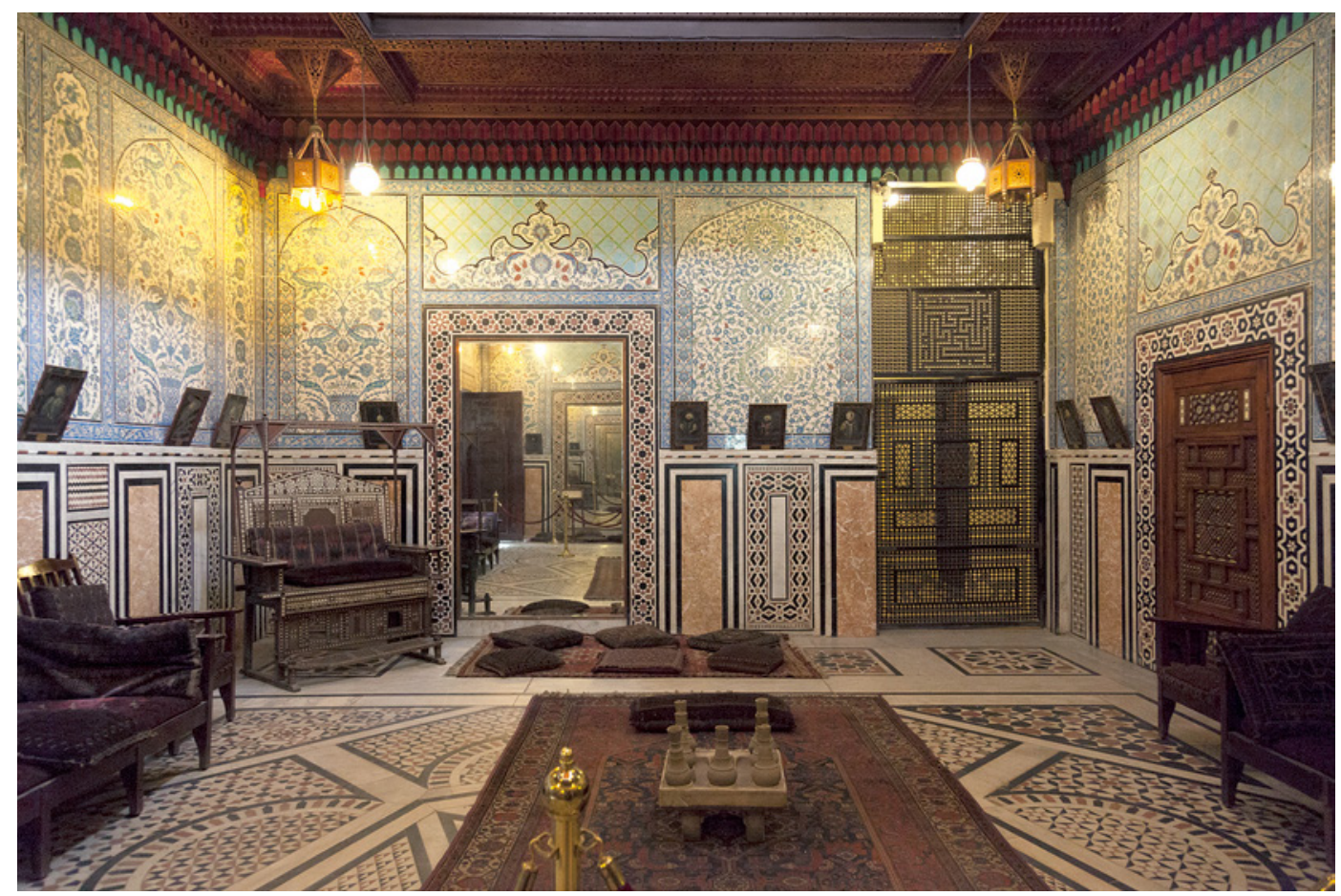

FIGURE 131 A Mamluk style room at Manyal Palace, Cairo, photographed in 2015

current notion of plundered cultural heritage. How Baudry's handling of spolia fit into the narrative, however, is still difficult to establish. Obviously, his experiments with architectural antiques in Egypt did not develop in a vacuum; there were plenty of surrounding pre-existing examples. More were to come.

\subsection{The Modern Repurposing of Salvage}

Twentieth-century Egypt had its own share of salvage being repurposed. All instances are connected to art collecting. Huda Sha'rawi (1879-1947), best known as an early advocate of women's rights in Egypt, but who was indeed a keen collector, had her villa on Qasr al-Nil Street, built in 1928-29, populated with salvage. The spoils included a mosque portal, fountains, hanging lamps, Iznik tiles, ceilings from Damascus, and painted doors in 'ajamı̄ style, possibly from Syria too. ${ }^{101}$ A 2019

101 Magda Baraka, The Egyptian Upper Class between Revolutions, 1919-1952 (Reading: Ithaca Press, 1998), 186; Images (20 February 1932): 6-7. exhibition in Cairo showed, from her collection, a tiled side table, with Damascene ceramics inserted into a modern frame. ${ }^{102}$ The Arab rooms installed at the house of Dr. 'Ali Bey Ibrahim, a carpet collector, had walls covered with historic woodwork framing tile panels made of Iznik, Egyptian and Damascene ceramics; on display were a sixteenthcentury candlestick, a thirteenth-century magic bowl, a vase blazoned to the emblems of Sultan al-Qalawun and Bukhara rugs. ${ }^{103}$ Prince Mehmed Tevfik (1875-1955) worked during three decades, from 1902 to 1929, with the help of antique dealer Kevork Ispenian, on the enlargement and refurbishment of Manyal Palace, a set of buildings and pavilions standing amidst a vast garden estate on

102 Ehab El-Labban, ed., Treasures of our Art Museums 3: Features from an Era (Cairo: n.p., 2019), 201-03 (exhibition 27 January-27 April 2019, Aisha Fahmy Centre of Arts, Cairo).

103 Nelly Vaucher-Zananiri, "Les grandes collections égyptiennes," L'Art vivant 5 (15 January 1929):92-5; Shirley Johnston, Egyptian Palaces and Villas, 1808-1960 (Cairo: AUC Press, 2006), 143-45. 
Rawda Island in Cairo. Several historic rooms were installed: a Damascus room dated 119o AH/1776 AD, a Persian room, a Maghribi room and a Second Empire one, salvaged from the Khedivial Palace at Giza. In his endeavour, the prince was not only salvaging the remnants of Middle Eastern art, but indeed the traces of his personal dynastic history. Open to visitors since the 196 os as an example of a modern aristocratic residence in Cairo, Manyal Palace is above all a museum of period rooms and a perfect illustration of the dissemination of salvaging and reuse amongst Egyptian grandees at the time. ${ }^{104}$ (Fig. 131)

Another distinguished example is the suite of style and epoch rooms arranged within the ensemble known as Bayt al-Kiridliyya [the house of the Cretan lady]. The site comprises a house erected in 1631 and an adjacent one dated 1540 that were registered as historic in the late 1920 and consequently placed under the authority of the Comité de conservation des monuments de l'art arabe. In May 1935, one of the members of this Comité, Major Gayer-Anderson (1881-1945), a devoted collector of Islamic art, was granted permission to rent the place and install his collections, on the condition that he would help fund the restoration work. The British Army doctor contributed by arranging a set of historic rooms, displaying objects and furnishings that he bequeathed to the Egyptian Nation in 1938. Among the newly installed rooms were a Persian style room decorated with Qajar paintings, an early nineteenth-century sitting room acquired from the harem building of Yaghan ${ }^{105}$ Palace in Suq al-Silah at the time of its demolition in $1937,{ }^{106}$ and an 'ajami room dated 1691 that the Major had purchased from Damascus for 250 Egyptian pounds (roughly equivalent to $£ 250$ then) with a view to having the panelled room re-erected

104 Mahmud Mohammad Tawfiq, Dalïl mathaf Qasr alManyal [A Guide to the Manyal Palace] (Cairo: Public Printing Press, 1979), 2, 29 sq.

105 The surname of this prominent Turkish family related to the ruling family is indifferently spelled Yekhen, Yeken, Yakan, Yaghan in the sources.

106 A Guide to the Gayer-Anderson Pasha Museum (Cairo: n.p., 1946), 19. at al-Kiridliyya. ${ }^{107}$ A Queen Ann Room arranged as a dining-room was also installed. ${ }^{108}$ Within a historic structure, the invented Bayt al-Kiridliyya denotes much the same fantasy that shaped Manyal Palace. The ensemble became a museum on the death of the Major and bears his name today. ${ }^{109}$ Not all objects displayed, however, date from Gayer-Anderson's time: many were added afterwards, and refurnishment continues today on a grand scale. In a way, Gayer-Anderson's project is being completed by the current curators of the Museum.

The most striking recontextualisation that took place in Cairo's modern architecture involves a stone inscribed in Himyaritic, the Semitic language spoken in ancient Yemen in the first century BC. It was inserted by scholar Ahmad Zaki (1867-1934) into the wall of the funerary mosque that he designed in 1933 for his and his wife's mausoleum on the banks of the Nile at Giza. A plaque placed above the ancient stone tells its story: the epigraphic piece came from the Ghumdan Palace, the residence of the kings of Saba, and it had been offered by the Imam Yahia, the ruler of Yemen, to the Egyptian scholar during his visit to Sanaa in 1926. The precious pre-Islamic fragment testifies to the cause that Zaki, nicknamed shaykh al-urüba [Sheikh of Arabism], championed throughout his life: the unity of Arabs beyond borders and confessions. It is also a prime material manifestation of historical consciousness and antiquarianism

107 Mahmud Ahmad et al., "10. Acquisition d'une chambre ancienne," Comité de Conservation des Monuments de l'Art Arabe 38 (1936-1940, printed 1944): 219-20. The canopied-bed labelled "Indo-Persian" that supposedly came with it, bears striking resemblance with the "Arab" or Hejazi bed used by Saint-Maurice. The uncertainty of the labels is a good illustration of how little is known about nineteenth-century furnishing in Cairo and how large its continental provenance was.

108 Nicholas Warner, Guide to the Gayer-Anderson Museum Cairo (Cairo: Supreme Council of Antiquities, 2003), passim. Louise Foxcroft, Gayer-Anderson: The Life and Afterlife of the Irish Pasha (Cairo: AuC Press, 2016), ch. 17 passim. 
in Egypt. ${ }^{110}$ Today [2019] administrated by the Ministry of Endowments, Ahmad Zaki's mosque is thus inscribed within an ancient and prestigious lineage that cuts across denominational identities. ${ }^{111}$

The display of relics from the past, and their architectural recontextualisation, served multiple purposes in Egypt. In ancient and pre-modern times, spolia and salvage acted as emblems of victory, were ascribed protective qualities or were meant to provide adornment. In contemporary times, they held artistic functions, expressed religious affinities, provided status and pedigree, recalled dynastic lineage or inscribed the present into the longue durée of Arab history. Meanings shifted from one time to another, as well as from one agent to another. At the heart of the phenomenon in the past two centuries, and cutting across national boundaries, was the act of collecting the past: a shared culture of collecting and re-enacting. Whether practiced by Egyptians or non-Egyptians, reuse has been kept alive, and with it the specialised skills required to perform its practice. It is not known if Baudry benefited from such a workforce. Traditions, however, are not exempt from inventions and interpolations. When the owner of a well-established Egyptian firm specialising in demolition and salvage (that of 'Abd al-Wuddud, active from the 1930s), was asked the name of his trade in Arabic, the response spontaneously brought up, unexpectedly, the French noun démolisseur [demolisher]. ${ }^{112}$ For some reason, the existing Arabic substantive naming those

110 Ahmad Zaki's antiquarianism is discussed by Ahmed El Shamsy in his talk "Philology, Forgery, and Superstition: The Fierce Debate over the Shrine of Sayyida Zaynab in Early Twentieth-Century Egypt," given at the Bard college's symposium Antiquarianism in the Islamic World, 9-10 May 2019, podcast available at [https://www.bgc .bard.edu/events/927/o9-may-2019-symposium-anti quarianism].

111 Mercedes Volait, "Ahmad Zaki: Une vie à la croisée de plusieurs mondes," in Ahmad Zaki, L'Univers à Paris, un lettré égyptien à l'Exposition Universelle de 1900 (Paris: Norma, 2015), 21-7.

112 Personal interview, 2011. who practiced the trade of hadm [demolition], the hädimin, was not considered a suitable term, ${ }^{113}$ as if the French practice of designing with antiques, after all, left its own mark on the Egyptian tradition of reuse.

\section{The Social Outreach of Revivalism}

The pattern of historical recreation formed at Cluny by the collector Alexandre Du Sommerard, and continued by his son Edmond, fired many an imagination in Europe all throughout the nineteenth century among art lovers, but also among writers, antiquarians and collectors, and ultimately, the general public. Historicist recreations with salvage had long been the preserve of the exclusive elite, mainly aristocrats and artists, but copies developed in their wake. The mechanical reproduction of artworks rendered the historicist pursuit more widely accessible to the average consumer. The attraction of the middle-classes to the displays at the Musée de Cluny is wellencapsulated by an engraving illustrating a typical Sunday afternoon at Cluny in 1881, with hordes of viewers closely observing and commenting on the objects on display, the copies of which, in plaster casts, could be acquired on the very premises at the end of the visit.114 (Fig 132) The scene takes place in the so-called bedroom of François I ${ }^{115}$ and the setting is not less significant: Cluny not only offered a window onto the medieval past, it

113 A French dictionary gives khārib, pl. khurrub for "démolisseur," formed on the root $k h-r-b$, Dictionnaire français-arabe par le père J-B. Belot (Beirut: Imprimerie catholique, 1939), I:319.

114 Manuel Charpy, "Passés intérieurs: reconstitutions et mises en scène du passé dans les appartements et les magasins de Paris et New York au XIX ${ }^{\mathrm{e}}$ siècle," in The Period Rooms: Allestimenti storici tra arte, collezionismo e museologia, eds. Sandra Costa et al. (Bologna: Bononia University Press, 2016), 133-42.

115 The bed is most likely a nineteenth-century piece, Muriel Barbier, "Le lit dit 'de François I ${ }^{\text {er' }}$ de la collection Du Sommerard: des questions en attente de réponses," In Situ 2019 [DOI: 10.400o/insitu.24164]. 
facilitated intimate access to the trappings of royalty. (Fig. 133)

Emulations of Cluny were not the sole purpose of the mechanical reproduction of art. As Victor Lottin de Laval (1810-1903), the antiquarian who invented Lottinoplastie, a reproduction technique to which he gave his name, argued in 1857:

À une époque comme la nôtre où tant de gens ont leur chez soi, où l'on aime les belles choses qui ne coûtent pas cher, où chacun rêve un hôtel Cluny en miniature, c'est, il me semble, une grand bonne fortune que de pouvoir instantanément, sans peine, sans apprentissage d'art, se faire une salle de l'Alhambra, un Balâ-Khanè persan, un oratoire gothique, une chambre à coucher de la Renaissance, un divan constantinopolitain, un boudoir du temps fleuri de la Régence. ${ }^{116}$

Lottin de Laval goes on to point out further benefits of mechanical reproduction of art: it allowed everyone to easily afford what only "rulers, public monuments, some grandees and very few artists" could attain thanks to "abundant money, effort and genius." It brought to all the delight of the "unforeseen and the unknown."117 In short, reproductions of interiors, whether historic or exotic, catered to the same needs: one's own home, affordable aesthetics, and technical ease. Reproducing a room from the Alhambra, a Persian upper

116 Victor Lottin de Laval, Manuel complet de Lottinoplastique: l'art du moulage de la sculpture en bas-relief et en creux mis à la portée de tout le monde, sans notions élémentaires, sans apprentissage d'art précédé d'une histoire de cette découverte (Paris: Dusacq, 1857), 92-3. "At a time like our own when so many people possess a home of their own, when one loves beautiful things that are inexpensive, when everyone dreams of a Cluny mansion in miniature, it seems, to me, good fortune that one is able to procure, instantaneously, without trouble or artistic training, a room from the Alhambra, a Persian upper chamber, a Gothic chapel, a Renaissance bedroom, a Turkish den, or a Regency boudoir." [My translation]

117 Lottin de Laval, Manuel complet de Lottinoplastique, 93. chamber, a Renaissance bedroom, a Gothic chapel, a Turkish den or a miniature Cluny, as enumerated in the quotation, were not pursuits of a very different order: all corresponded to the same craving for bringing lost pasts into the present, at home and with limited effort. Mechanical replica made the past or the wider world accessible to all, and not only to the privileged. They prompted social equity.

Art historians have used the concepts of (material) spolia in se and (virtual) spolia in re to distinguish reuse from imitation, while drawing attention to their entanglements: in many instances physical adoption worked hand-in-hand with citation and reproduction. ${ }^{118}$ The same phenomenon applies here: material spolia cannot be separated from the style of spolia.

\section{1 "Anglo-Arab" and Other "Saracenic Rooms" in Europe}

A similar dissemination pattern to the one highlighted for "mini-Clunys" can be observed with Arab style or Islamic Revival: from the exclusive sphere of a few well-acquainted collectors, they reached larger audiences thanks to the industry of mass-market reproduction. Instrumental in the process were firms such as Liberty and Co in England. The department store had started its Oriental offerings, as seen in Chapter 2, by marketing Eastern antiques provided by agents in the Middle East, but it soon moved towards commissioning locally-made Oriental style furniture to workshops in the Middle East, and finally embarked upon producing at home its own line of "Anglo-Arab" furnishings and interiors. The British craze for imported old furniture had begun to wane (and the products itself might have been exhausted), while an interest was growing in new "art furniture." On the other hand, British furnituremaking praised itself for producing goods superior

118 Richard Brilliant, "I piedistalli del giardino di Boboli: spolia in se, spolia in re," Prospettiva 31 (Oct. 1982): 2-17. 


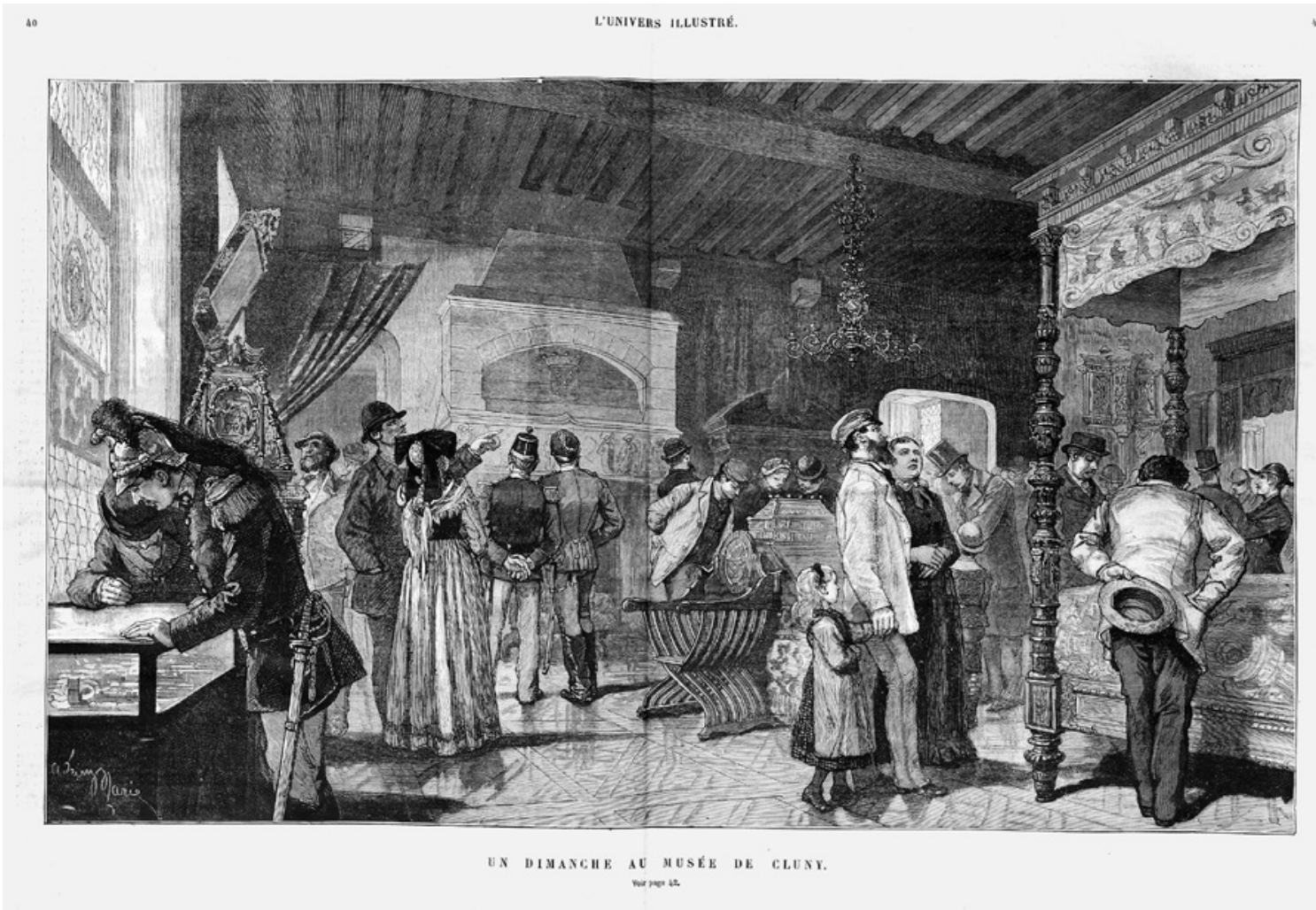

FIgURE 132 After Adrien Marie, Un Dimanche au Musée de Cluny. [A Sunday afternoon at the Musée de Cluny in Paris in 1881]. Engraving

L'UNIVERS ILLUSTRÉ, 15 JANUARY 1881: 40-1

to anything made elsewhere, 119 and the country was indeed recognised for its manufacturing power. No wonder, then, that Liberty's would think that commodities made at home could have stronger national prospects. In $188_{3}$, the firm hired Leonard Francis Wyburd (1865-1958), a very young interior designer, for the purpose. The artist was to run Liberty's special branch for "Eastern decorations" and ultimately their Furnishings and Decoration studio for the following two decades. ${ }^{120}$ The 1889 catalogue of Liberty products advertised the concept in the following terms:

The adaptation of Eastern forms to English homes has been specially studied by Liberty and Co, and many beautiful rooms in town

119 "Market for English goods," Furniture and decoration 2, issue no. 24 (1st December 1891): 169.

120 Bennett, Liberty's Furniture 1875-1915, 89-94. and country have been decorated and furnished by them. The prominent advantage of such a treatment is picturesqueness of effect, adaptability to any shape of room, richness of colour, and the fact that it can be carried out, if desired, in an inexpensive manner. ${ }^{121}$

Among the examples offered was Anglo-Arab Hall no. 1 "with woodwork all treated in a simple and characteristic decorative manner and the fireplace faced with rich Persian tiles." Anglo-Arab no. 2 relied on walls, curtains and divan covers of "soft and durable Eastern fabrics," while Anglo-Arab no. 3 combined both traits. Original coloured designs could be obtained on demand. "Musharabêyeh" lattice was liberally proposed for

121 The Liberty Hand-Book of Sketches: With prices \& other information for Artistic \& Economic Decoration of Furniture (London: Liberty \& Co., 1889), 35. 


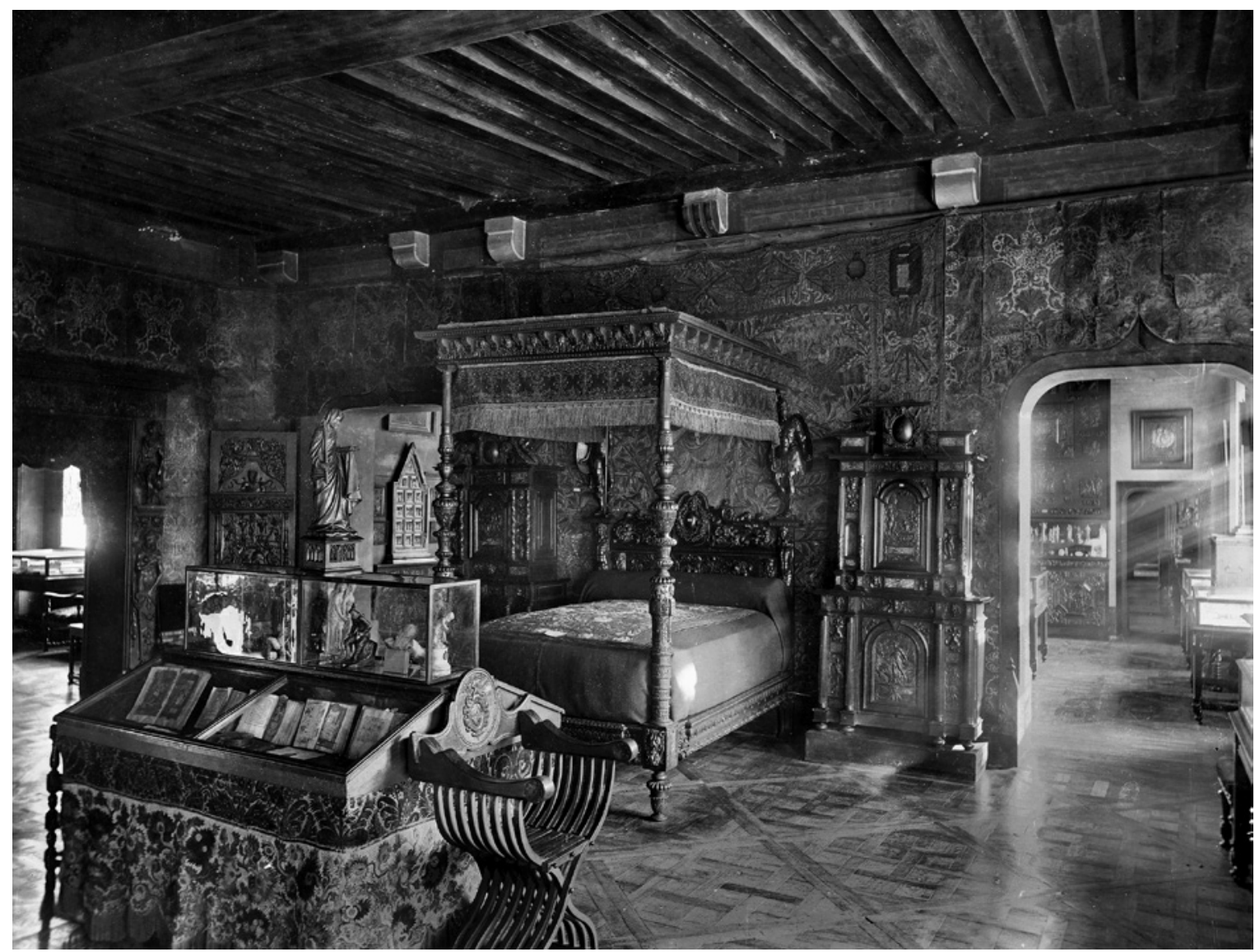

FIGURE 133 Anonymous, La chambre dite "de François Ier" de l'ancien musée de Cluny. [Alleged room of Francis I at the old Musée de Cluny], before 1900

PARIS, LA PARISIENNE DE PHOTOGRAPHIE, 12606-8

archways, windows, openings and many other purposes. The firm announced in 1884 that:

Liberty and Co have constantly a stock of Old and Modern Musharabiyeh Lattice which they adapt for such purposes as Window blinds, Door-heads, Screens for Halls and Landings and Panels for Doors, and which can be stained or painted as required. ${ }^{122}$

Lattice was thus salvaged on a grand scale by the British Department store. Customers could indeed order "Liberty's Anglo-Arab fitments," such as "Liberty's saddle bag lounging chairs," and all kinds of cabinets and seats. The Kharan chair was

122 Liberty's Art Furniture (London: Liberty \& Co., [1884]), 31 . advertised as making "very tasteful use of the fascinating artistic product of Muhammadan Egypt" represented by lattice work. ${ }^{123}$ (Fig. 134) When looking at the models marketed, one realises that in fact some of the Arab-style seats, or indeed Egyptian-style for that matter, to be seen today in Cairo's affluent interiors may be products manufactured by Liberty's.

In this way, individuality was becoming affordable. In the age of personality, at a time when interiors had become a crucial marker, it mattered to be allowed to achieve distinction at limited cost. ${ }^{124}$

123 John Moyr-Smith, Ornamental Interiors, Ancient and Modern (London: C. Lockwood, 1887), 141.

124 Deborah Cohen, Household Gods: The British and Their Possessions (New Haven: Yale University Press, 2006), 128-3o. 


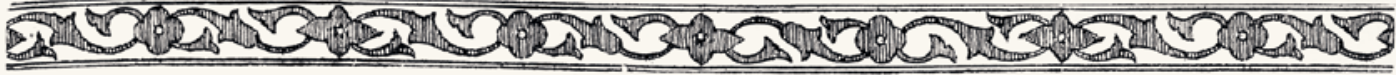

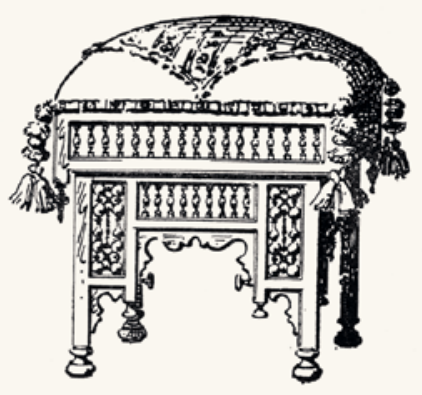

The "Cairo,"

Top of seat richly stuffed and covered in Plush, trimmed with Gimp and Tassels, 25 s. and $25 \mathrm{I5s}$.
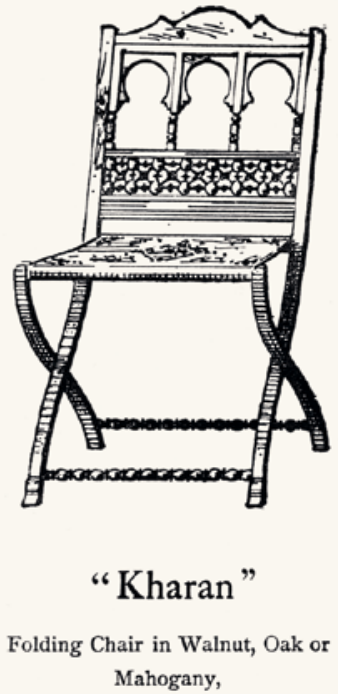

$35 /-$

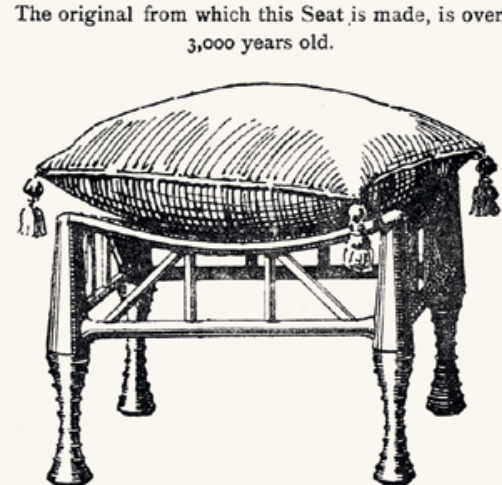

The "Thebes,"

a most comfortable seat, in Walnut, Mahogany or Oak, top covered with Leather, 95-

Best Down Cushions, covered in any coloured Plush, and trimmed with Silk Braid and Tassels,

50 -

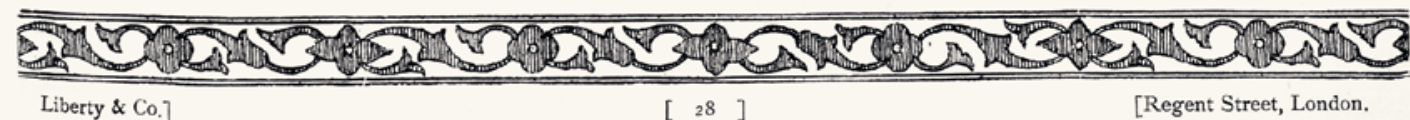

FIGURE 134 Three Liberty \& Co's iconic seats inspired by Egypt: the "Cairo," "Kharan," and “Thebes.” The latter was manufactured according to a design by Leonard Wyburd patented in 1884 .

LIBERTY'S ART FURNITURE [1884]: 28

(Fig. 135) The other British firm, H. \& J. Cooper, on the market of "Arabian and Moorish" interiors since 1875 , catered to a much higher segment of the demand. Their Oriental rooms were extravagant, as exemplified by the ones installed in 1893 for Mr and Mrs Wallace Carpenter at 28 Ashley Place in London. (Fig. 136) Similarly to Liberty's, the Coopers worked with lattice screens "brought from the fronts of old houses in Cairo,"125 but they used it in a very liberal way, such as carrying a mashrabiya indoors in this instance! The sight produced in a drawing-room was rather peculiar;

125 Moyr-Smith, Ornamental Interiors, 142. no less striking was the adjoining boudoir placed under a tent. ${ }^{126}$ In contrast:

Messrs. Liberty \& Co ... have fitted up apartments quite in the same style as the foregoing [H. and J. Cooper], and, from a commercial point of view, their display is more practical, because their 'adaptation of Arabian Art' as they define it - is really consistent with inexpensive furnishing. They have applied

12628 Ashley Place is fully illustrated in The Bedford Lemere Collection of photographs (Swindon, Historic England archive). 


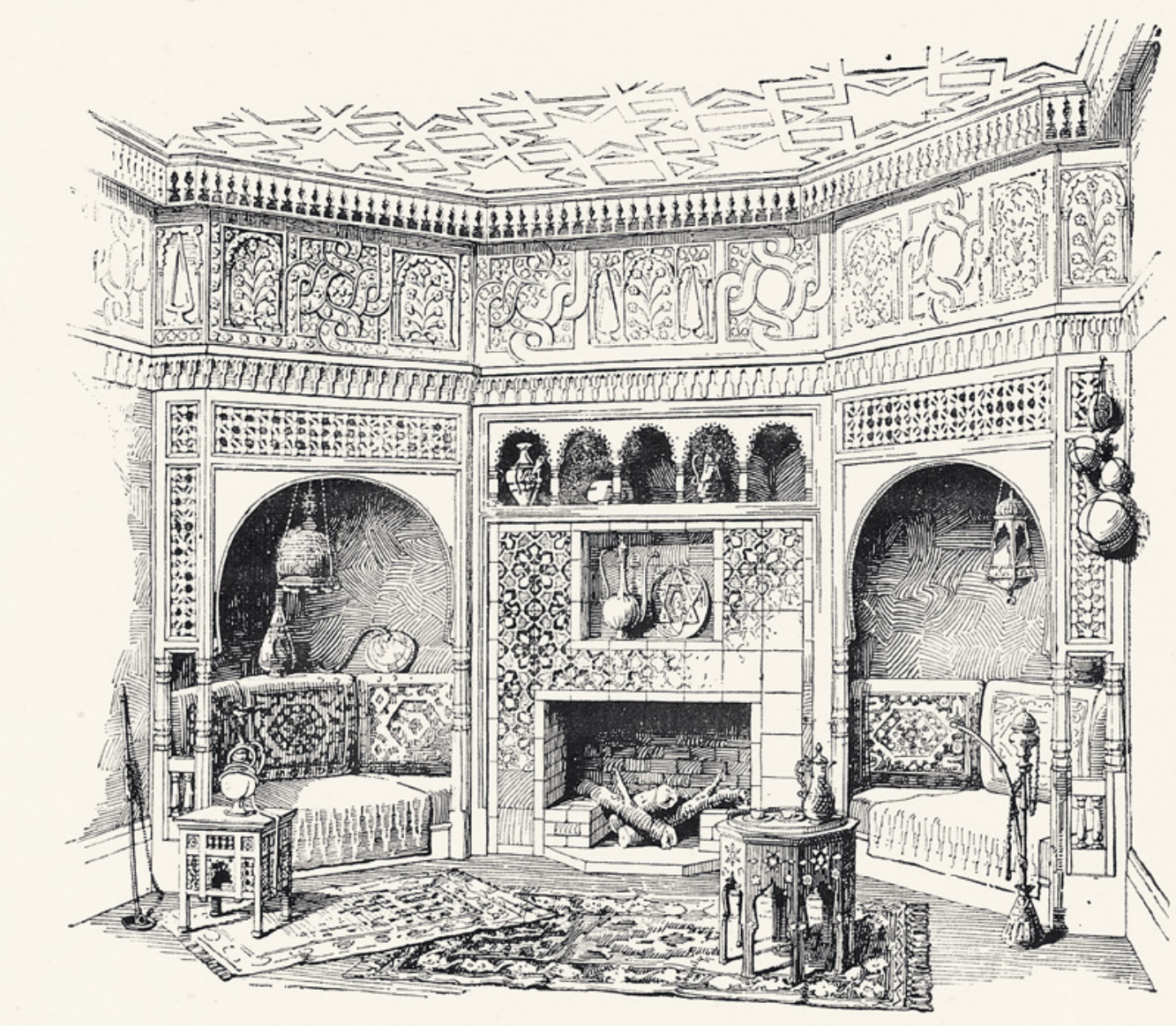

SARACENIC SMOKING ROOM, by LIBERTY \& CO.

I 5

FIGURE 135 Saracenic Smoking Room marketed by Liberty \& Co in the 188os. Engraving TYPE OF DECORATION \& FURNITURE BY LIBERTY \& CO. LTD C. 1890:15

the style, more or less successfully, to cheap forms of ordinary furniture. ${ }^{127}$

The "Arabian" vogue did not last long in Britain. It diminished from 1900 onwards with the rise of Modernism. The brief involvement of Liberty's in the style eventually fell into complete oblivion. The brand is forever associated with the volutes of

127 From The Cabinet Maker and Art Furnisher, 1 April 1884, quoted in Barbara Morris, Liberty Design, 1874-1914 (London: Pyramid Books).
Art Nouveau, and posterior flower-patterned fabrics, and Wyburd himself is mostly remembered today as the designer of the Thebes stool, a musthave patented in 1884 that continued to be sold until 1919. Egyptomania had been more enduring than Islamophilia in Europe, and continues to be, although, recently, "Oriental" elements are becoming fashionable again. ${ }^{128}$

\footnotetext{
128 My gratitude to Fuschia Hart for pointing out that Liberty's has recently opened a large Oriental section for high-end interiors.
} 


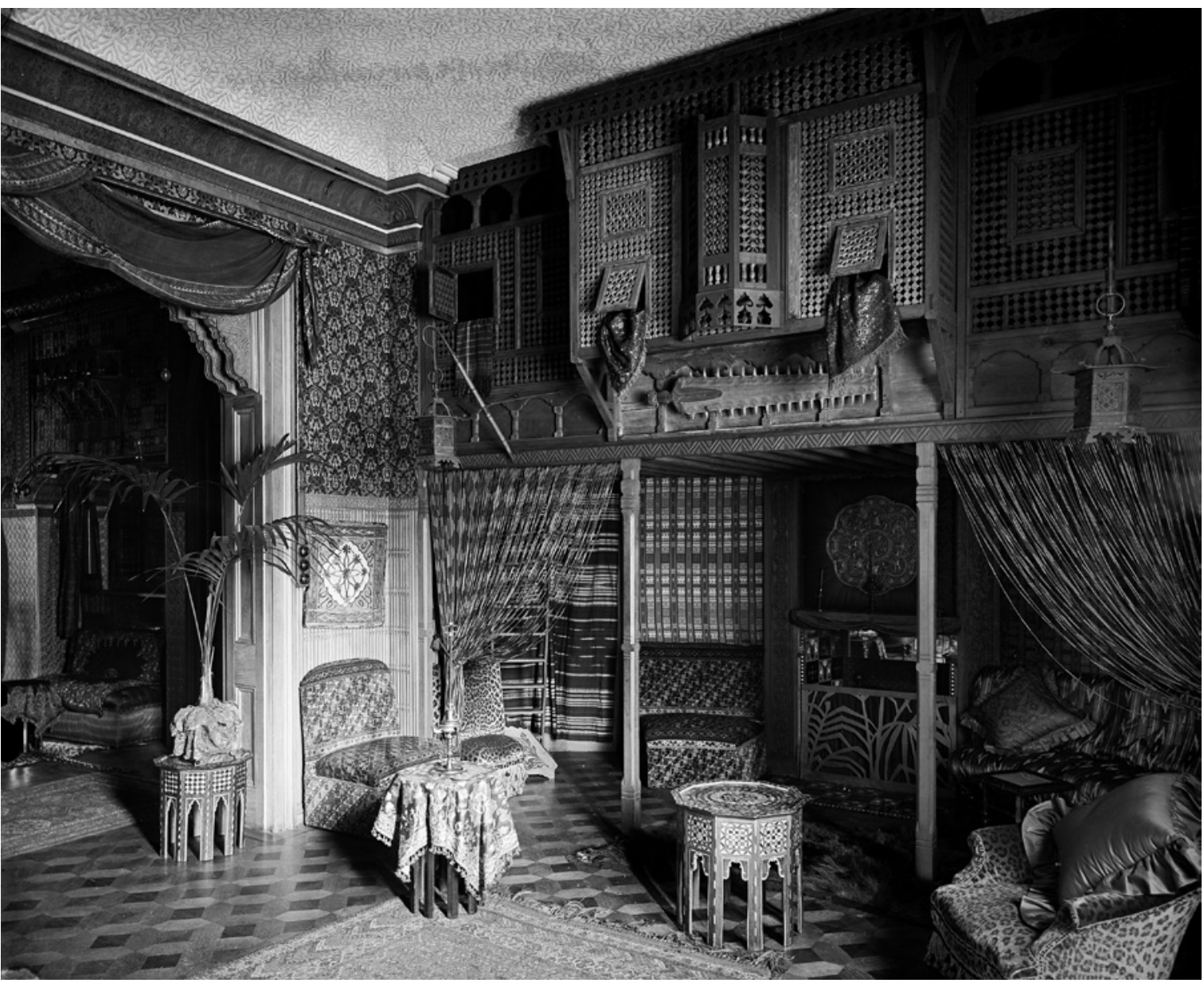

FIGURE 136 Henry Bedford Lemere, The sitting room at 28 Ashley Place, London, decorated in a Moorish style, 22 August 1893. The interior was designed by the firm H. and J. Cooper for George Wallace Carpenter. Photographic negative. $30 \times 25.4 \mathrm{~cm}$ SWINDON, HISTORIC ENGLAND ARCHIVE, THE BEDFORD LEMERE COLLECTION, BL12330/005A

\subsection{Islamic Revival Rooms in Cairo}

Rooms in "Arabic style" 129 became a standard in Egyptian upper and middle-class homes in the 1920 and 1930 os (their previous history is less well-known). They continued to be installed into the 1950s and 196os, and they can still be found in many an Egyptian household. Their appearance and contents did not differ greatly from their British, or French counterparts. The room

129 Caption of pl. 32, Kingdom of Egypt, Ministry of Public works, State buildings department, Photographs of various buildings in Egypt, s.d. [1931-32]. designed c. 1930 by Egyptian architect 'Ali Labib Gabr (1898-1966) for the house of Mujib Fathi Bey on Pyramids Road in Cairo is a rare dated example for which photographs are available. It incorporates the ingredients encountered elsewhere: a carved ceiling circled with rows of stalactites, hanging kilims, chairs with lattice infill, a cut out metal hanging lamp, "Mecca cushions" (that is, made from saddle bags), and the typical Parvis, or Parvis-style, cupboard (visible in the far left corner of the photograph). (Fig. 137) The only difference from its European counterparts lies in the type of salvage then available and the minutia of the 


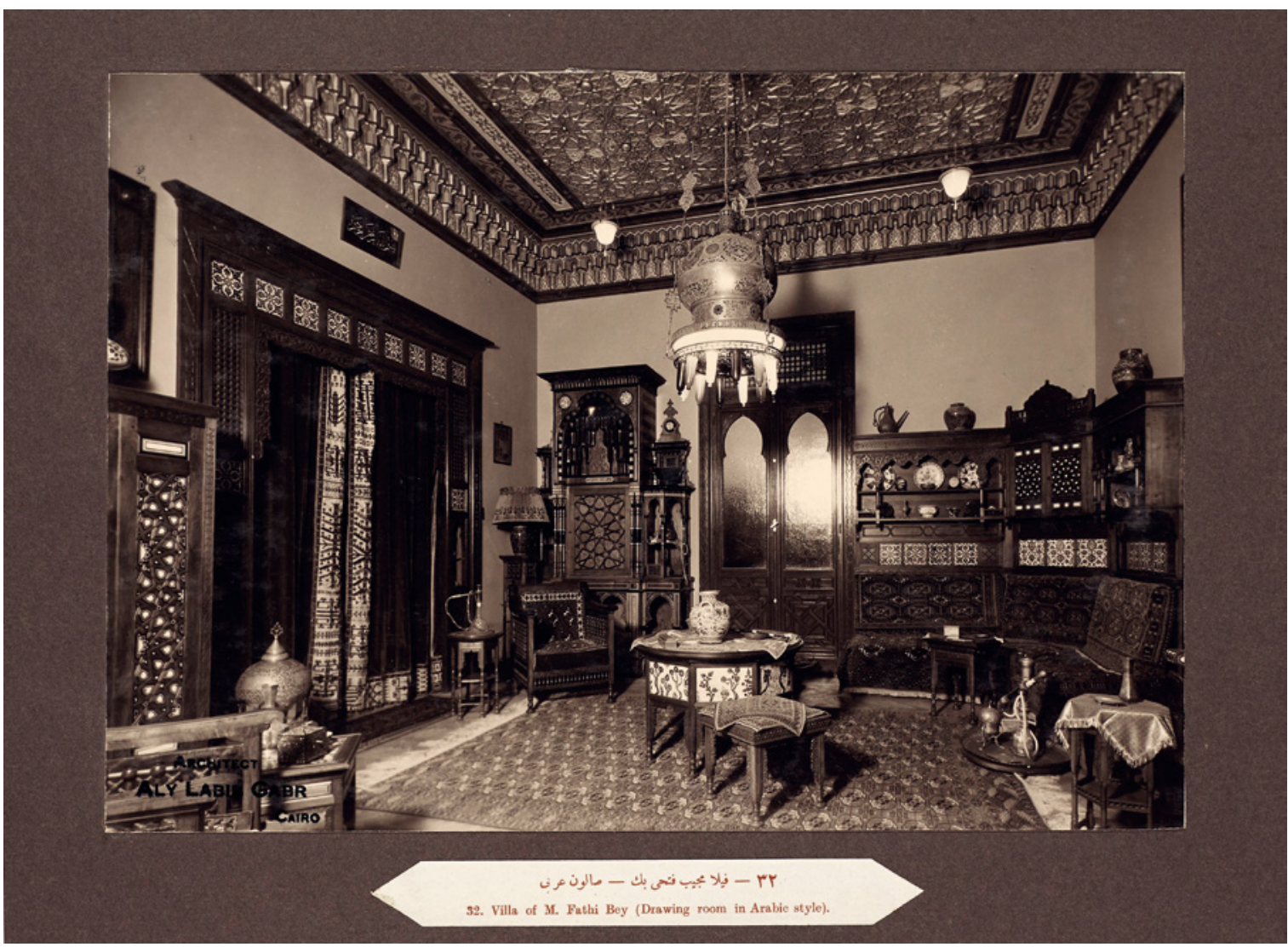

FIGURE 137
Anonymous. Villa of Fathi Bey (Drawing room in Arabic style), Cairo, 1930s. The room is captioned in Arabic as "Arab salon." It was designed by architect 'Ali Labib Gabr. Mounted albumen print. $20 \times 25 \mathrm{~cm}$. Kingdom of Egypt, Ministry of Public works, State buildings department, Photographs of various buildings in Egypt, s.d. [1931-32], pl. 32
CAIRO, INSTITUT FRANÇAIS D'ARCHÉOLOGIE ORIENTALE'S LIBRARY, SPECIAL COLLECTIONS, 44318

handicraft. The tiles inserted in the cabinet over the sofa may have been copies, rather than reused items. Authentic tiles had been lacking since the 189os. In 1898, when Max de Zogheb, and his architect Max Herz Bey, conceived a monumental Cairene house in "the spirit and the good taste of the best Saracenic work," tiles had to be manufactured anew. Some were produced in Venice from patterns sent by de Zogheb while others were ordered from Austria and the reputed Cantagalli brothers from Florence provided their share. ${ }^{130}$

130 Walter Tyndale, An Artist in Egypt (London: Hodder \& Stoughton, 1912), 174-75; Istvan Ormos, Max Herz Pasha (1856-1919), 391-402.
An Islamic style interior frequently belongs to a sequence of rooms representing various times and places. At Mujib Fathi Bey's villa, the "Arab salon" [sālūn 'arabì ] coexisted with a hall in the Louis XIII style and a neo-classical morning room. ${ }^{131}$ Arab rooms were commonly paired with Far Eastern ones. Villa Harari, built in the 1920 s in the picturesque neighbourhood of Garden-City in Cairo, possessed an even more diverse range of style rooms. (Fig. 138) Its auction brochure lists a grand Hall in the Arabesque style opening into a den

131 Kingdom of Egypt, Ministry of Public works, State buildings department, Photographs of Various Buildings in Egypt, s.d., [1931-32], pl. 29-31. 


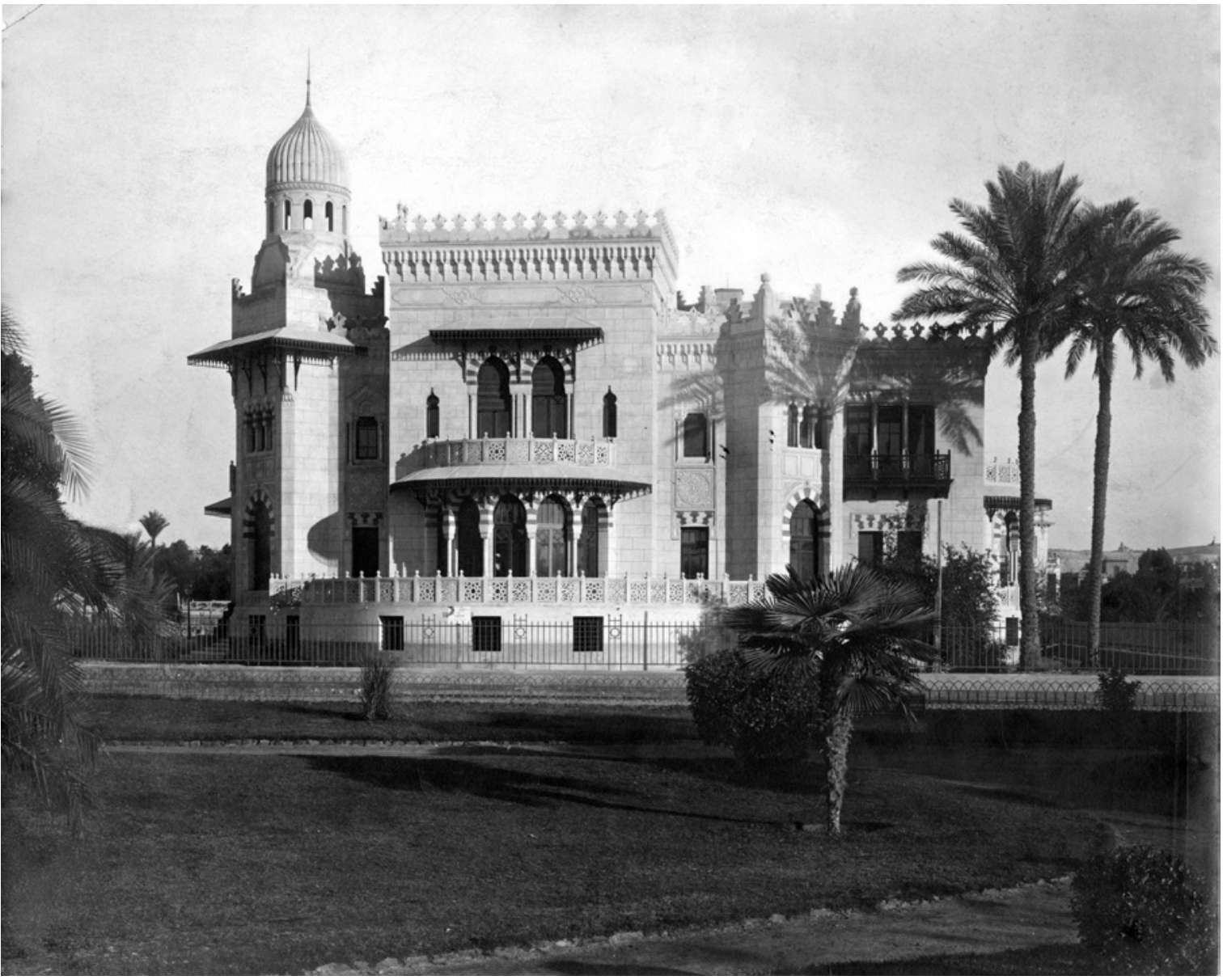

FIGURE 138 Anonymous, Villa Harari, Garden-City (Cairo), undated. The house was built in 1921, architect unknown. Albumen print. $13 \times 18 \mathrm{~cm}$

PARIS, CENTRE D'ARCHIVES DE L'INSTITUT FRANÇAIS D'ARCHITECTURE, FONDS BÉTONS ARMÉS HENNEBIQUE, 076 IFA, 1-B-160

used as a smoking room, a large study furnished in Empire style, a Chinese room decorated by a Cairo-based Ukrainian artist named Stoloff and a Renaissance-style sitting-room featuring a copy of a chimney from the Palace of Fontainebleau. ${ }^{132}$ Renaissance style was the quintessence of chic for the international upper class; the Rothschilds used the style liberally for their Parisian mansions. The overall composition of the external appearance of Villa Harari, when contrasted with facades at the Saint-Maurice house for instance, suggests

132 Auction brochure published on [http://www.egy.com/ gardencity/] on 3 September 1998, accessed on 2o June $202 \mathrm{O}$. in turn how different Islamic Revival aesthetics could be from one architect to another, from one patron to another, or from one temporal frame to another.

Reputedly built in 1907 and recently reopened as an art centre after a full restoration, the palace of Aisha Fahmi in Zamalek features an Etruscan style room with bare breasted dancing figures performing music and comedy, a carved oak panelled billiard-room in the like of one at a British country house, a hall with overdoors filled with eighteenthcentury French decorative genre painting, and a Japanesque room.

The mélange des styles found in the houses of well-to-do Egyptians was analysed in the 1940s by 
the distinguished scientist Mustafa Musharrafa $(1898-1950)$ as a sign of conflicted identity:

Few signs reflect the conflict in our lives between the old and the new, Arabic and Pharaonic, Western and Eastern, more than this disturbing tendency; to furnish one room in the Arabesque style, another in Louis XVI's, a third in the Pharaonic's and yet a few steel chairs and glass tables scattered over the halls and balconies of the house. It is a conflict which comprehends our life to-day. ${ }^{133}$

Historian Magda Baraka aptly observes that what Musharrafa saw as an incongruity could be read by other contemporaries, or the previous generation, "as an expression of the reconciliation in their lifestyle and outlook of their indigenousness and their cosmopolitanism."134 Written four decades apart, both points of views primarily express mind-sets and opinions clearly anchored in their own time, one marked, on the one hand, by the rising tide of independence, and the other, by disenchantment with its outcome. But Magda Baraka brings up issues that haven't lost their currency in Egypt. The way one fashioned his or her interior went hand-in-hand with an ease at multlinguism in speech and writing (Arabic, French and English, and indeed Italian or Greek were commonly spoken and intertwined) and direct access to varied cultures. Hybrid tastes in interior decoration resonated with an unorthodox appreciation of music that could encompass both Beethoven and the Egyptian diva Umm Kulthum. It was a form of cultural fusion long before the late twentieth-century music industry coined and popularised the idea of World fusion and Crossover.

If Islamic Revival interiors in Egypt resembled their Western equivalents in their materiality, at

133 M.M. Mosharrafa, Cultural Survey of Modern Egypt (London: Longmans, Green and C ${ }^{\circ}, 1947$ ), 44.

134 Magda Baraka, The Egyptian Upper Class between Revolutions, 1919-1952 (Reading: Ithaca Press, 1998), 186. least in part, paths diverged as to the social significance of the decorative style. The implications in terms of cultural belonging were deeper for Egyptian society than for its European counterpart. Inhabiting Oriental interiors was commonly detached from local culture and language in the case of Europeans. In contrast, Egyptian "Arab parlours" were dwelled by individuals identifying to Arab culture, and having access to many other ones ... When it comes to multilingualism alone, a clear divide separates those familiar with multiple languages (in the Middle East) and those who were not (in Europe). That the fashion for Anglo-Arab interiors was short-lived in Britain - as it was across Europe - is also an indication of divergent fates on either side of the Mediterranean.

\section{Islamic Art as Intrinsically Architectural}

Islamic antiques collected by travelers or residents in the Middle East during the 1870s were frequently interrelated with the fashioning of historicist interiors at home, or indeed abroad. They brought a seal of authenticity to pursuits that had long been pure fantasy and artifice as demonstrated by most examples of eighteenth-century Turquerie. ${ }^{135}$ A late impersonation of Turquerie in interior design offers an eloquent contrast with all Islamic Revival interiors encountered so far. It was called a "Turkish room" and was implemented in 1833 at the Académie de France in Rome by the artist Horace Vernet (1798-1863) during his directorship. Apart from being devoid of objects, the room features tiles, ceiling paintings in the Etruscan style, a colour scheme in reds, yellows and blues, and geometric patterns that point concretely to no precedent, even remotely. The work was done by the master builder Francesco Oslenghi, under the supervision of architect Domenico Cacchiatelli. The tiles of this Camera alla turca, as it was called

\footnotetext{
135 Nebahat Avcıoglu, Turquerie and the Politics of Representation, 1737-1876 (Farnham, UK: Ashgate Publishers, 2011).
} 
in the primary sources, came from Naples. ${ }^{136}$ The Arabic script over the door provides the main link with the region, as it reproduces the first lines of the Throne verse from the second surah of the Qur'an (2:255) $)^{137}$ celebrating the uniqueness of

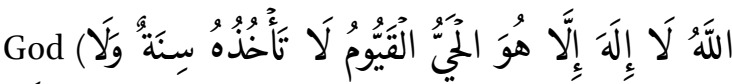
(نَّم) (it is one of its best-known verses, often recited as a protection against evil spirits and frequently inscribed on buildings. (Fig. 139) One wonders again if Vernet knew the meaning of the written words and had selected them on purpose. To be sure, the room predated his ventures East (though not a brief trip to Algeria in spring 1833), and might have turned out differently if arranged afterwards. But it demonstrates the developments in Islamic Revival rooms which took place since the early nineteenth century.

Since the 186os, affluent aesthetes or artists had typically indulged in Islamic style rooms arranged as "quasi living museums." Objects served as furniture (or props); fragments of architectural salvage from demolished structures, whether tiles, marble slabs or carved woodwork, were used for floors, doors, surface decoration or ceilings. The spolia were in some instances complemented by replicas of historic ornament cast in plaster, as well as by Revival design. This decorative genre was nurtured by a specific high end collecting culture mourning irretrievable pasts, which was typical of postrevolutionary France, and more broadly, Europe, and was to give birth in parallel to Gothic Revival. With the refurbishing of the Gothic mansion (later Museum) of Cluny in the 183 os, an inspiring model had been set. A "Cluny arabe" was the phrase used

136 Isabelle Chave et al., eds., Correspondance des directeurs de l'Académie de France à Rome. Horace Vernet (18281834) (Paris/Rome: Société de l'Histoire de l'Art français/Académie de France à Rome, 2010), 459-6o.

I am indebted to one of the anonymous reviewers of the manuscript for the identification of the verse. It is usually translated as "God, there is no God but He; the living, the self-subsisting, no slumber can seize him nor sleep." to qualify one such Revival achievement in Cairo in 1876 .

The "allure of the old" and the "Oriental obsession" did not speak only to French society. ${ }^{138}$ Frederic Leighton embarked on a similar scheme of an "Arab Hall" in London in 1877. The fashion for antiques developed in parallel within British society as a reaction "against the grotesqueries of Victorian manufacture" and a "fast-living age:" old furniture helped acquire an "aura of pedigree."139 With time, (Islamic) style rooms became popular worldwide among the middle-class, in Europe as in Egypt. A German instance, Urach Palace in Stuttgart, has been mentioned earlier. Swiss examples have been recently unearthed. ${ }^{140}$ During his residence in Cairo as a German diplomat from 1896 to 1910, collector Max Freiherr von Oppenheim indulged in Islamic-style interiors, as most Islamic art collectors did. ${ }^{141}$ The taste lasted longer in Egypt for it carried more vital meanings in a country experiencing political and cultural assaults from a dominant Europe, than it did elsewhere.

Islamic style aesthetic interiors thus represented a very consistent decorative genre during the age of the mechanical reproduction of art. It attested to a form of consumption and an understanding of Islamic visual and material culture that were intrinsically architectural in nature. This would change with other types of objects entering the world of collectors and scholars of Islamic

138 John Sweetman, The Oriental Obsession: Islamic Inspiration in British and American Art and Architecture 1500-1920 (Cambridge: Cambridge University Press, 1987).

139 Cohen, Household Gods, 146-47.

140 Der Orient in der Schweiz. Neo-islamische Architektur und Interieurs des 19. und 20. Jahrhunderts [The Orient in Switzerland: 19th and 2oth Century Neo-Islamic Architecture and Interior Design], eds. Francine Giese, Leïla el-Wakil, and Ariane Varela Braga (Berlin/ Munich/Boston: De Gruyter, 2019).

141 Gabriele Teichmann, "Max von Oppenheim: Sammler, Gastgeber, Grenzgänger," in Abenteuer Orient: Max von Oppenheim und seine Entdeckung des Tell Halaf, eds. Ulrike Dubiel et al. (Tübingen/Berlin: Ernst Wasmuth, 2014), 28-35. 


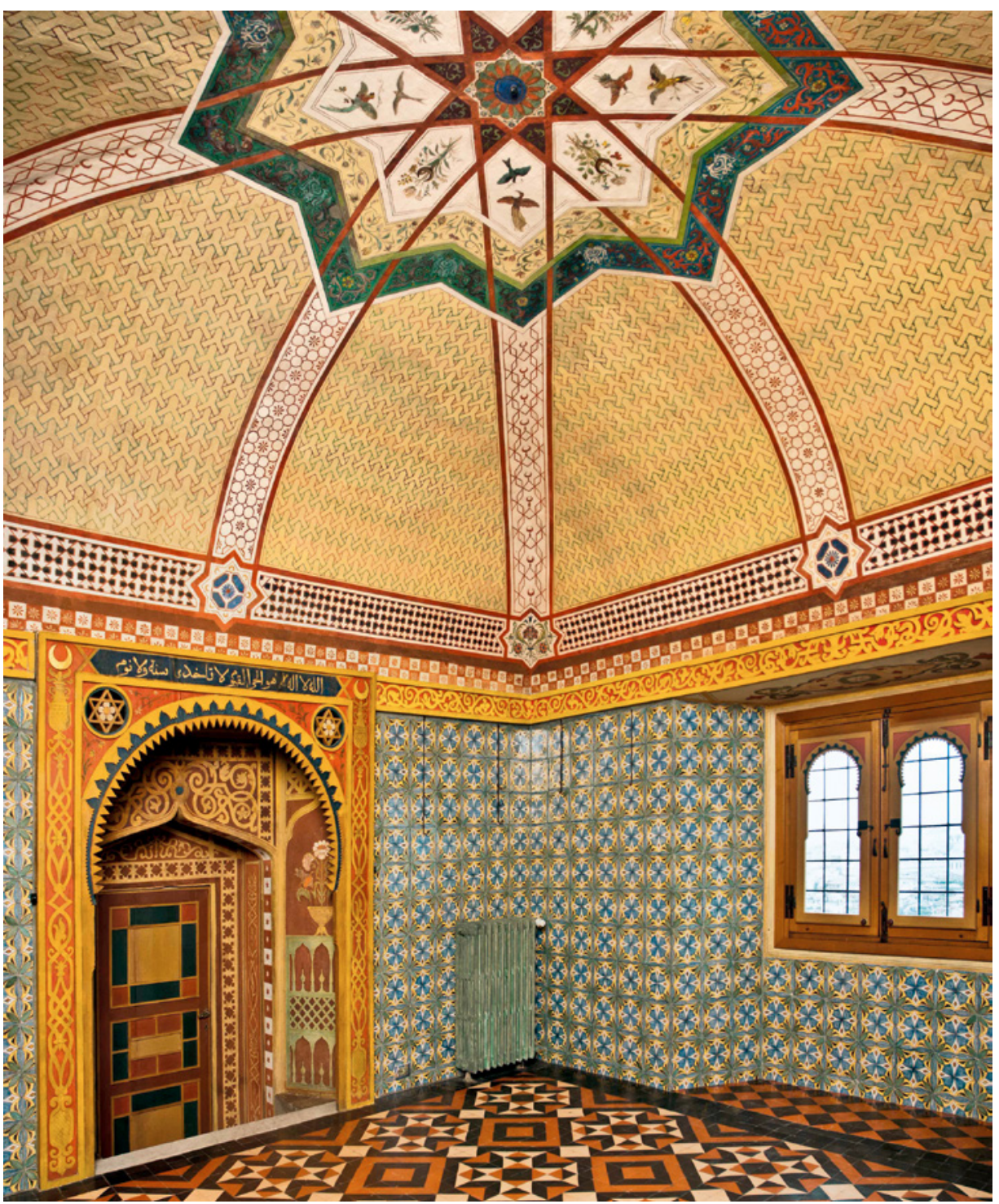

FIGURE 139 The Turkish room at the French Academy in Rome, designed by artist Horace Vernet in 1833 , photographed in 2020

Art alike, such as illuminated manuscripts from Persia. ${ }^{142}$

A clear-cut response as to the impact of the Egyptian culture of reuse on the development of interiors with Islamic salvage cannot be given. More comparative research is needed to contrast the rooms discussed here with other types of

142 Stephen Vernoit, "Islamic art and architecture: An overview of scholarship and collecting, c. 1850-c. 1950," in Discovering Islamic Art, ed. Vernoit, 1-61 (31-6). historic reconstructions in an array of contexts and conjunctures. One thing can be asserted with some certainty: in Egypt Cluny-type recreations found a perfect terrain on which to blossom. Modern revivals of Mamluk and Ottoman domestic architecture carried out in Egypt can thus be safely located at the intersection of two cultures of the Antique: the lasting tradition of Egyptian reuse and the French post-revolutionary understanding of "restoration" as a modern reconstruction of past architecture with authentic fragments, copies and imitations. They eventually came into fusion. 